
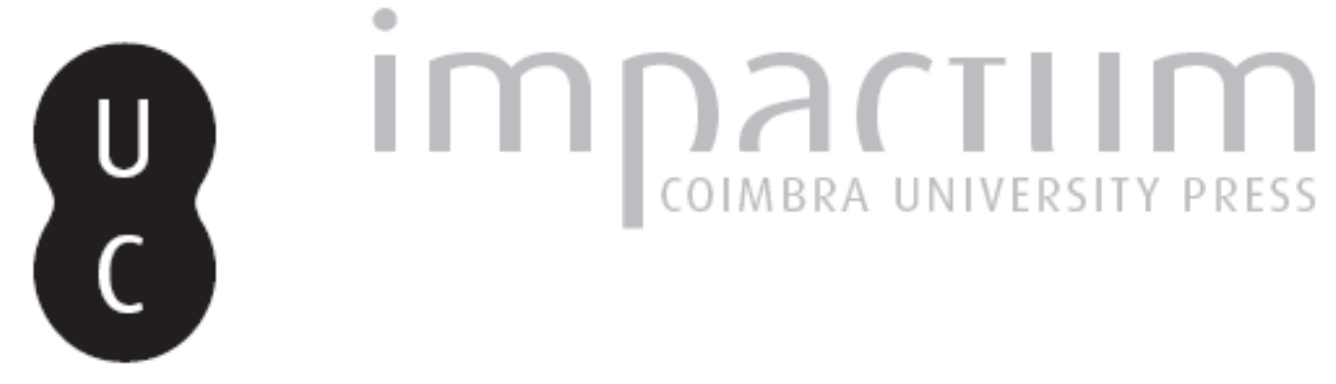

\title{
Barragens romanas do distrito de Castelo Branco e Barragem de Alferrarede
} \author{
Autor(es): $\quad$ Quíntela, António de Carvalho; Cardoso, João Luís; Mascarenhas, José
}

Publicado por: Imprensa da Universidade de Coimbra

URL persistente:

URI:http://hdl.handle.net/10316.2/45461

DOI:

DOI:https://dx.doi.org/10.14195/1647-8657_34_3

Accessed : $\quad$ 26-Apr-2023 10:43:02

A navegação consulta e descarregamento dos títulos inseridos nas Bibliotecas Digitais UC Digitalis, UC Pombalina e UC Impactum, pressupõem a aceitação plena e sem reservas dos Termos e Condições de Uso destas Bibliotecas Digitais, disponíveis em https://digitalis.uc.pt/pt-pt/termos.

Conforme exposto nos referidos Termos e Condições de Uso, o descarregamento de títulos de acesso restrito requer uma licença válida de autorização devendo o utilizador aceder ao(s) documento(s) a partir de um endereço de IP da instituição detentora da supramencionada licença.

Ao utilizador é apenas permitido o descarregamento para uso pessoal, pelo que o emprego do(s) título(s) descarregado(s) para outro fim, designadamente comercial, carece de autorização do respetivo autor ou editor da obra.

Na medida em que todas as obras da UC Digitalis se encontram protegidas pelo Código do Direito de Autor e Direitos Conexos e demais legislação aplicável, toda a cópia, parcial ou total, deste documento, nos casos em que é legalmente admitida, deverá conter ou fazer-se acompanhar por este aviso.

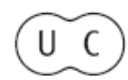


UNIVERSIDADE DE COIMBRA

FACULDADE DE LETRAS

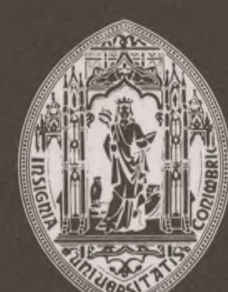

CONIMBRIGA

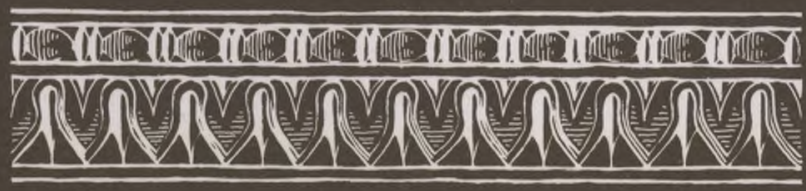

VOLUME XXXIV - 1995

INSTITUTO DE ARQUEOLOGIA 


\section{ANTÓNIO DE CARVALHO QUínTELA}

Professor Catedrático. Departamento de Engenharia Civil

Instituto Superior Técnico - Universidade Técnica de Lisboa

\section{JoÃo LUÍS CARDOSO}

Professor Auxiliar. Universidade Nova de Lisboa

Coordenador do Centro de Estudos Arqueológicos

do Concelho de Oeiras - Câmara Municipal de Oeiras

\section{José MANUEL MASCARENHAS}

Professor Auxiliar. Departamento de Ecologia - Universidade de Évora

\section{BARRAGENS ROMANAS DO DISTRITO DE CASTELO BRANCO \\ E BARRAGEM DE ALFERRAREDE}

"Conimbriga” XXXIV (1995) p. 75-127

RESUMO: Descrevem-se os vestígios das barragens do distrito de Castelo Branco atribuídas ao período romano e procura-se reconstituir as suas características iniciais. Caracteriza-se ainda a barragem de Alferrarede, pós-romana, em bom estado de conservação, de duplo muro e aterro intermédio, e apresentam-se dados retirados da bibliografia relativos à "Presa de Penamacor", que sofreu um rombo no primeiro quartel do século XVI e da qual não há vestígios.

Das oito barragens atribuídas ao período romano, duas são de alvenaria e seis de terra. Estas últimas parecem não ter sido dotadas de descarregadores de superfície (nem de órgãos fixos para assegurar a utilização da água). A conservação de vestígios dos aterros poderá dever-se à existência de brechas que asseguram a passagem da água sem galgamento.

Algumas das barragens de terra eram estruturas importantes, que envolveram grandes movimentos de terra e a utilização de boas técnicas de compactação como atesta a caracterização geotècnica. As maiores barragens são a da Egitânia e da Lameira com alturas de 11 e $9 \mathrm{~m}$ e volumes de aterro de 12000 e $16000 \mathrm{~m}^{3}$, respectivamente.

Conimbriga, 34 (1995) 75-127 
As barragens de terra estudadas assumem, assim, grande importância no Mundo Romano em face da escassez de estruturas comparáveis, exclusivamente de terra.

A atribuição das barragens ao período romano apoia-se nos seguintes factos:

- vestígios romanos nas imediações de cinco das barragens;

- analogias entre elas relativamente aos tipos construtivos;

- referência à barragem da Orca em documento de 1505;

- história da ocupação da região no período pós-romano;

- enquadramento histórico da construção de barragens medievais na Europa.

A finalidade de grande parte das barragens deve ter sido o apoio à mineração, visto verificar-se para cada caso, pelo menos, uma das seguintes situações:

- inexistência de villae a jusante;

- desconhecimento de vestígios de canais de adução entre as barragens e os habitats romanos a jusante, quando existem;

- recurso verificado a nascentes para a alimentação das villae nas proximidades das barragens (ou possibilidade do recurso a nascentes ou poços);

- inexistência a jusante de solos propícios à rega.

A ocupação romana da região e, particularmente, a actividade mineira são documentadas com base na bibliografia, sendo referenciados os achados de numerosos tesouros (joias e moedas) que atestam acumulação de riqueza, em resultado daquela actividade mineira.

SUMMARY: The dams vestiges in the district of Castelo Branco, attributed by the authors to the Romans, are described and the original characteristics of those dams are reconstituted.

Two post-Roman dams, probably built in sixteenth century, are also described:

- the Penamacor masonry dam, from which there are no vestiges, whose notice results only from bibliography;

- the $13 \mathrm{~m}$ high Alferrarede dam, with two masonry walls and an earthfill core, which remains in a fairly good condition.

From the eight dams atributed to the Romans, two were built in masonry and six in earthfill.

The earthfill dams do not seem to have been provided with spillways and outlets. The vestiges of each of these dams consist of two earthfill reaches separated by a gap, which, nowadays, allows the water to pass. Some of those earth dams were important structures which implied the movement of large amount of earthfill and the use of adequate 
compactation technics, as shown by the geotechnical charaterization. The most important dams are those of Egitania and Lameira, with heights of 11 and $9 \mathrm{~m}$ and an earthfill volume of 12000 and $16000 \mathrm{~m}^{3}$, respectively.

The earth dams studied in this work were of great importance within the Roman World, considering the scarcity of comparable earth structures (without a masonry wall).

The dams were attributed to the Roman period in the basis of the following facts:

- existence of Roman vestiges in the neighbourhood of five dams;

- dam construction types analogies;

- reference to Orca dam in a document of the year 1505;

- history of the country occupation in post-Roman period;

- history of dam construction in Europe.

The purpose of the most of studied dams was, very probably, the water supply to gold mining, because, at least, one of the following situations occurs for each dam:

- non-existence of villae downstream of the dams;

- absence of connecting channels vestiges between the dams and the roman habitats downstream, whenever existent;

- non-existence of appropriated soils to irrigation, downstream of the dams.

- existence of springs that were surely used to supply water to villae, located near the dams; the use of nearby springs and wells was also possible in other sites.

The Roman occupation of the country and namely the gold mining activity are documented by the bibliography and the discovery of many treasures (jewels and coins) proves the accumulation of wealth as result of gold mining activity. 
(Página deixada propositadamente em branco) 


\section{1 - PREÂMBULO}

O presente trabalho Barragens Romanas do Distrito de Castelo Branco e Barragem de Alferrarede foi elaborado para a Direcção-Geral dos Recursos Naturais, DGRN, pelo Centro de Estudos de Hidrossistemas (CEHIDRO) do Departamento de Engenharia Civil, do Instituto Superior Técnico. Inserido na linha de investigação do CEHIDRO sobre história e arqueologia da Hidráulica, foi realizado pela mesma equipa que no CEHIDRO já apresentara vários trabalhos na linha referida.

Tem como objectivo contribuir para o inventário e caracterização das barragens romanas do distrito de Castelo Branco, bem como caracterizar a barragem pós-romana de Alferrarede (ponte-represa, como é localmente conhecida).

De algumas das barragens estudadas já os autores haviam apresentado breves referências no seu trabalho de 1986 Aproveitamentos Hidráulicos Romanos a Sul do Tejo.

Não obstante a metodologia seguida no estudo e descrita no Capítulo 2, admite-se a possibilidade de existirem naquele distrito vestígios de barragens romanas não reconhecidas pelos autores, especialmente em zonas de mais difícil acesso.

No Capítulo 3 faz-se a apresentação geral dos principais resultados decorrentes da caracterização das barragens reconhecidas, a qual é objecto do Capítulo 4.

Os aspectos dessas barragens que foram considerados relevantes são destacados no Capítulo 5, separadamente para as barragens romanas de terra e de alvenaria e para a barragem de Alferrarede. Nesse capítulo são descritas barragens de aterro pré-romanas e romanas doutras regiões, com a finalidade de possibilitar o enquadramento para 
o estudo apresentado das barragens de terra romanas do distrito de Castelo Branco e de demonstrar a importância que as mesmas assumem, perante a escassez no mundo de vestígios de barragens romanas deste tipo.

O Capítulo 6 analisa os problemas relativos à finalidade e cronologia das barragens estudadas e, finalmente, o Capítulo 7 contém as principais conclusões do estudo.

\section{2 - METOdOLOGIA DO ESTUdO}

Na sua obra de 1986 Aproveitamentos Hidráulicos Romanos a Sul do Tejo os autores caracterizaram, embora sumariamente, algumas barragens a norte daquele rio, devido ao especial interesse de que as mesmas se revestiam. Incluíram a barragem pós-romana de Alferrarede e as seguintes barragens romanas do distrito de Castelo Branco:

- Rochoso,

- Egitânia,

- Nossa Senhora de Mércoles,

- Lameira,

de terra, com excepção da de Nossa Senhora de Mércoles (de alvenaria). As barragens do Rochoso e de Nossa Senhora de Mércoles haviam sido referenciadas pela primeira vez pelos autores, tendo as de Alferrarede e Egitânia sido objecto de curtas referências anteriores.

A investigação bibliográfica e o reconhecimento de campo, com base no exame da fotografia aérea, a que se procedeu no período inicial do presente trabalho, permitiram identificar mais duas barragens de terra:

- Lajinha,

- Orca,

esta última citada por SILVA 1988.

Para todas as barragens anteriormente mencionadas foram obtidos, pela Direcção-Geral dos Recursos Naturais, levantamentos topográficos respeitantes a:

- planta da albufeira (escala 1:2000);

- planta da barragem e da área envolvente (escala 1:200);

- perfis transversais da barragem (escala 1:50). 
Nestes levantamentos, as cotas altimétricas são referidas ao zero topográfico e as coordenadas em planta ao sistema Hayford-Gauss (com origem em Vila de Rei). Posteriormente, foi reconhecida mais uma barragem de terra (Monforte) e outra de alvenaria (Souto do Penedo), esta última de vestígios escassos.

As barragens de que se obtiveram os levantamentos topográficos mencionados são caracterizadas pormenorizadamente no Capítulo 4 com base nesses levantamentos e no reconhecimento local. As restantes barragens são caracterizadas com base unicamente no reconhecimento local.

Como orientação para a localização de barragens romanas e em complemento da recolha da bibliografia, procedeu-se, com base na consulta da Carta Militar de Portugal à escala 1:25000 e do correspondente inventário toponímico, à identificação de locais designados por topónimos sugestivos, tais como "presa", "represa", "muro" e "lagoa". Em seguida, efectuou-se a selecção de locais a serem posteriormente objecto de exame estereoscópico em fotografia aérea vertical à escala aproximada de 1/27000, da Missão USAF, de 1958.

Aquele exame permitiu selecionar os locais onde mais provavelmente se poderiam situar vestígios de barragens romanas, a maioria das quais foi objecto de reconhecimento de campo.

Em consequência desse reconhecimento, identificaram-se numerosas estruturas pós-romanas (açudes e barragens) e uma única barragem romana, a da Lajinha.

No decurso do reconhecimento de campo, que incidiu também sobre as barragens romanas identificadas a partir de referências bibliográficas, procurou-se obter dos habitantes informações relativas à localização exacta das barragens e à existência doutros vestígios romanos que permitissem avaliar a finalidade das mesmas.

\section{3 - APRESENTAÇÃO GERAL DOS RESULTADOS OBTIDOS}

Localizam-se na Fig. 1 as barragens reconhecidas cujas principais características se resumem no Quadro 1, com excepção da presa de Penamacor (há muito desaparecida e de que só existe informação bibliográfica).

Salvo a de Alferrarede, as barragens constantes do Quadro 1 são consideradas como romanas. Deve notar-se a importância de se terem 
reconhecido, adjacentes àquela barragem, do lado de montante e ao nível do coroamento, blocos de opus signinum, que parecem levar a admitir a anterior existência no local de uma barragem romana, com altura aproximada da actual.

No Quadro 1 não se inclui a presa de Penamacor, provavelmente de origem romana, de alvenaria, mas de que não existem vestígios na actualidade. Um documento genealógico dá conta da sua rotura no primeiro quartel do século XVII e de outras vicissitudes, o qual é resumido no item 4.10 .

As bacias hidrográficas, com excepção das da Orca e do Souto do Penedo, desenvolvem-se em zonas com precipitação anual média inferior a cerca $800 \mathrm{~mm}$. Os cursos de água em que foram construídas as barragens, com a excepção já mencionada, têm regime muito irregular, estando secos em grande parte do ano. Assim, o aproveitamento das águas superficiais só era possível mediante o armazenamento da água em albufeiras, a criar por barragens.

A distribuição do número de barragens em função da área da respectiva bacia hidrográfica, $A(\mathrm{~km} 2)$, é a seguinte:

$$
\begin{array}{llll}
\mathrm{A}=0,7 & -1 & \text { barragem (aterro); } & \\
9,2>\mathrm{A}>2,4 & -5 & \text { barragens (4 de aterro e } & 1 \text { de alvenaria); } \\
39,7>\mathrm{A}>12,3 & -3 & \text { barragens (1 de aterro e } & 2 \text { de alvenaria). }
\end{array}
$$

De muito pequeno porte é apenas a barragem de Nossa Senhora

\begin{tabular}{|c|c|}
\hline $\begin{array}{c}H=2,5 \\
8>H>5,0\end{array}$ & $\begin{array}{l}-1 \text { barragem (alvenaria); } \\
-5 \text { barragens (aterro); }\end{array}$ \\
\hline $13,5>\mathrm{H}>11$ & -3 barragens ( 2 de aterro e \\
\hline
\end{tabular}
de Mércoles, com a altura máxima de $2,5 \mathrm{~m}$. A distribuição do número de barragens por alturas máximas, $\mathrm{H}(\mathrm{m})$, é a seguinte: 
Quadro 1 - Barragens Romanas do Distrito de Castelo Branco

e Barragem de Alferrarede

(Ordenadas de norte para sul)

\begin{tabular}{|c|c|c|c|c|}
\hline Designação & $\begin{array}{c}\text { Tipologia } \\
\text { e volume do } \\
\text { aterro, } \mathrm{V}\left(\mathrm{m}^{\wedge}\right)\end{array}$ & $\begin{array}{l}\text { Altura, H } \\
\text { Desenvol., } \\
\text { L(m) }\end{array}$ & $\begin{array}{c}\text { Á. da bacia } \\
\text { hidrográ. } \\
(\mathrm{km} 2)\end{array}$ & $\begin{array}{l}\text { Albufeira } \\
\left.\text { Vol., V (m }{ }^{3}\right) \\
\text { Desenvol., } \\
\text { D (m) }\end{array}$ \\
\hline $\begin{array}{c}\text { Lajinha } \\
\text { (Penamacor) }\end{array}$ & $\begin{array}{l}\text { Terra } \\
\mathrm{V}=*\end{array}$ & $\begin{array}{l}H=5,5 \\
L=100\end{array}$ & 2,4 & $\begin{array}{c}\mathrm{V}=45000 \\
\mathrm{D}=300\end{array}$ \\
\hline $\begin{array}{c}\text { Orca } \\
\text { (Fundão) }\end{array}$ & $\begin{array}{c}\text { Terra } \\
\mathrm{V}=8700\end{array}$ & $\begin{array}{c}\mathrm{H}=6 \\
\mathrm{~L}=145\end{array}$ & 7,1 & $\begin{array}{c}V=51000 \\
D=420\end{array}$ \\
\hline $\begin{array}{c}\text { Rochoso } \\
\text { (Idanha-a-Nova) }\end{array}$ & $\begin{array}{l}\text { Terra } \\
\mathrm{V}=*\end{array}$ & $\begin{array}{c}H=7 \\
L=116\end{array}$ & 0,7 & $\begin{array}{c}V=10600 \\
D=150\end{array}$ \\
\hline $\begin{array}{c}\text { Egitânia } \\
\text { (Idanha-a-Nova) }\end{array}$ & $\begin{array}{c}\text { Terra } \\
\mathrm{V}=12000\end{array}$ & $\begin{array}{c}\mathrm{H}=11 \\
\mathrm{~L}=110\end{array}$ & 23,9 & $\begin{array}{c}\mathrm{V}=180000 \\
\mathrm{D}=560\end{array}$ \\
\hline $\begin{array}{l}\text { N.S. de Mércoles } \\
\text { (Castelo Branco) }\end{array}$ & Alvenaria & $\begin{aligned} H & =2,5 \\
L & =60\end{aligned}$ & 12,3 & $\begin{array}{l}\mathrm{V}=7200 \\
\mathrm{D}=260\end{array}$ \\
\hline $\begin{array}{l}\text { Monforte } \\
\text { (Monforte) }\end{array}$ & $\begin{array}{l}\text { Terra } \\
\mathrm{V}=*\end{array}$ & $\begin{array}{c}H=5 \\
L=130\end{array}$ & 4,8 & - \\
\hline $\begin{array}{c}\text { Lameira } \\
\text { (V. Velha de Ródão) }\end{array}$ & $\begin{array}{c}\text { Terra } \\
\mathrm{V}=16000\end{array}$ & $\begin{array}{c}H=8 \\
L=380\end{array}$ & 9,2 & $\begin{array}{c}\mathrm{V}=840000 \\
\mathrm{D}=1330\end{array}$ \\
\hline $\begin{array}{l}\text { Souto do Penedo } \\
\text { (Vila de Rei) }\end{array}$ & Alvenaria & $\mathrm{H}=10$ & 5,3 & - \\
\hline $\begin{array}{l}\text { Alferrarede } \\
\text { (Abrantes) }\end{array}$ & $\begin{array}{l}\text { Duplo muro de } \\
\text { alvenaria e terra }\end{array}$ & $\begin{array}{c}\mathrm{H}=13,5 \\
\mathrm{~L}=55\end{array}$ & 39,7 & $\begin{array}{c}\mathrm{V}=147000 \\
\mathrm{D}=700\end{array}$ \\
\hline
\end{tabular}

* Estimativa carecendo de rigor.

O desenvolvimento das barragens de alvenaria de que se obtiveram levantamentos topográficos (Nossa Senhora de Mércoles e Alferrarede) pouco excede $50 \mathrm{~m}$; o das barragens de aterro varia entre 
cerca de 100 e $150 \mathrm{~m}$, com excepção da barragem da Lameira que atinge $380 \mathrm{~m}$.

O traçado das barragens é rectilíneo, com excepção da Lameira, em que o grande desenvolvimento e a topografia impuseram um traçado poligonal.

Nenhuma das barragens estudadas está presentemente em funcionamento, fazendo-se a passagem da água através de rombo aberto na zona do talvegue (ou de rombo na base, no caso da barragem de Alferrarede).

Não foram reconhecidos vestígios de descarregadores de cheias de superfície, a não ser na barragem da Egitânia, onde uma depressão, no encontro da margem direita, poderia ter funcionado como tal. Deve notar-se que a barragem de Alferrarede, muito mais recente e bem conservada, não apresenta actualmente descarregador de superfície, não obstante a área da bacia hidrográfica ser de $39,7 \mathrm{~km} 2$; uma galeria transversal à barragem, cuja abertura no paramento de montante parece ter sido obturada, poderá ter servido como descarregador.

Também não foram detectados vestígios de disposições para saída da água das albufeiras. Nas barragens de aterro, condutas com estas funções revestem-se de dificuldades especiais, não sendo de excluir a hipótese de elevação por rodas hidráulicas (hipótese citada por VITAFINZI1961) ou por outros aparelhos de elevação. No local do rombo na base da barragem de Alferrarede poderia ter existido uma conduta de saída de água.

E interessante registar o procedimento que no início do século XVII era adoptado para assegurar a protecção da presa de Penamacor contra o galgamento (alínea 4.2.11). Segundo a tradição, o lago (albufeira) necessitava, de quando em quando, de ser sangrado; no caso contrário, rebentaria. Em dia de festa em Penamacor, o sangrador demorou-se naquela vila e o lago rebentou. Por se tratar de uma barragem de alvenaria, admite-se que o lago pudesse facilmente ser sangrado através de um descarregador de superfície ou de uma descarga de fundo, com possibilidade de obturação.

As capacidades das albufeiras de que foram obtidos levantamentos topográficos, para as condições actuais de assoreamento e correspondentes às cotas admitidas para o coroamento, são:

- barragem da Lajinha

- barragem da Orca
$-45000 \mathrm{~m}^{3}$,

$-51000 \mathrm{~m}^{3}$, 
- barragem do Rochoso

- barragem da Egitânia

- barragem de N. Senhora de Mércoles

- barragem da Lameira

- barragem de Alferrarede
- $10600 \mathrm{~m}-1$

- $180000 \mathrm{~m}^{3}$,

- $7200 \mathrm{~m}^{3}$

- $840000 \mathrm{~m}-1$

- $147000 \mathrm{~m}^{3}$.

O assoreamento verificado nas albufeiras não é muito pronunciado, sendo acentuado no caso das barragens de Alferrarede e Rochoso e pequeno no caso da barragem da Lameira.

\section{4 - CARACTERIZAÇÃO DAS BARRAGENS}

\section{1 - Preâmbulo}

Procede-se neste capítulo à caracterização das barragens estudadas.

Para melhor sistematização, adoptou-se um modelo de ficha descritiva, no qual se indicam, para cada estrutura, as características principais relativas a:

- localização;

- área da bacia hidrográfica;

- tipo de barragem;

- características geométricas dos vestígios;

- características da albufeira.

Para além destas características, são mencionadas outras informações, incluindo as de natureza bibliográfica, susceptíveis de possibilitar a avaliação da cronologia e da finalidade respectivas, como indicado nas alíneas 7.1 e 7.2.

A informação que foi possível recolher não permitiu a elaboração de ficha descritiva da barragem do Souto do Penedo e da Presa de Penamacor, apresentando-se, todavia, nas alíneas 4.9 e 4.11 a síntese dos elementos recolhidos.

As coordenadas das plantas topográficas das barragens e das albufeiras referem-se ao sistema Hayford-Gauss com origem num ponto próximo de Vila de Rei. As plantas das bacias hidrográficas nos locais das barragens, reproduzidas a partir da carta $1 / 25000$, têm coordenadas com projecção de Gauss e origem no ponto de referência a oeste do Cabo de S. Vicente. 


\section{2 - Barragem da Lajinha}

A) CARACTERÍSTICAS PRINCIPAIS

1 - Localização

- Coordenadas quilométricas Gauss $\mathrm{M}=285,2 \mathrm{P}=349,2$

- Concelho de Penamacor.

- Ribeira do Vale do Gris (ou da Aldeia de João Pires), subafluente do Ponsul.

2 - Área da bacia hidrográfica (Fig. 2) 2,4 km²

3 - Barragem de terrra.

4 - Características geométricas iniciais

- Cota do coroamento $430,5 \mathrm{~m}$

- Cota do talvegue $425,0 \mathrm{~m}$

- Altura máxima (diferença das cotas anteriores) $\quad 5,5 \mathrm{~m}$

- Desenvolvimento $100 \mathrm{~m}$

- Volume do aterro Impossível de avaliar

5 - Características dos vestígios (Fig. 4 e 5; Fot. 1 e 2)

- Troços de aterro nas duas margens (mais longo o da margem direita).

- Largura da brecha na base

- Declive (V:H) dos paramentos (Perfil A-A, Fig. 5) de montante de jusante

- Caractertísticas do aterro: Saibro granítico.

6 - Características da albufeira, para a cota 431 m (Fig. 3)

- Área inundada $32000 \mathrm{~m}^{2}$

- Volume armazenado $45000 \mathrm{~m}^{3}$

- Desenvolvimento $300 \mathrm{~m}^{(*)}$

(*) Valores estimados a partir dos vestígios. 


\section{B) OUTRAS INFORMAÇÕES}

A ribeira, na zona da barragem, corre entre muros de pedra arrumada, existindo um pequeno dique de pedras e terra entre muros que provoca a retenção de água utilizada para rega. $\mathrm{O}$ topónimo presa, se bem que designe o local da barragem, é associado pelos residentes próximos àquela retenção de água e não aos vestígios da barragem.

$\mathrm{Na}$ margem direita, um pouco acima do leito notam-se blocos graníticos que se admite terem sido colocados para evitar o desmoronamento do aterro.

No decurso do reconhecimento de campo efectuado, encontraram-se abundantes vestígios de uma importante villa romana (Fig. 2), próximo do local onde existiu uma fonte e, segundo a tradição, apareciam "mouras encantadas". Observaram-se à superfície restos de escória, na margem direita e na margem esquerda. O local da referida fonte é referenciada na carta $1 / 25000$ por fonte das Casas, embora, segundo informação localmente obtida, seja designado por fonte das Cales pelos habitantes da aldeia de João Pires e por fonte das Cais pelos habitantes de Aranhas.

É admissível que a alimentação de água da villa se realizasse através de caleiras (cales) que transportariam a água da fonte.

A jusante da barragem, o vale é relativamente aberto e os solos propícios à agricultura, em especial, os aluviões do fundo do vale. Deve notar-se que na actualidade existem várias hortas regadas a partir de poços, o que, também a verificar-se na época romana, não justificaria uma barragem destinada à rega.

A utilização da água represada pela barragem seria a rega ou a lavagem de minério.

Crê-se que a villa atrás mencionada esteja inédita, pois a mais próxima de que há referência (LEITÃO, M. 1983; ALARCÃO, J. 1988 b) se situa junto da Tapada do Cabeço, $500 \mathrm{~m}$ para sul.

\section{3 - Barragens da Orca}

A) CARACTERÍSTICAS PRINCIPAIS

1 - Localização

- Coordenadas quilométricas Gauss $\mathrm{M}=267,3 \mathrm{P}=343,0$ 
- Concelho de Fundão.

- Ribeira das Paredes (bacia hidrográfica do Ponsul).

2 - Área da bacia hidrográfica (Fig.6)

3 - Barragem de terra.

4 - Características geométricàs iniciais

- Cota do coroamento

- Cota do talvegue

- Altura máxima (diferença das cotas anteriores)

- Desenvolvimento

- Volume do aterro

5 - Características dos vestígios (Fig. 8 e 9; Fot. 3 a 5)

- Troços de aterro nas duas margens (bem definido o da margem esquerda com cerca de $90 \mathrm{~m}$, apenas se conservando o arranque do da margem direita).

- Largura da brecha $40 \mathrm{~m}$

- Declive (V:H) dos paramentos (Perfil A-A, Fig. 9) de montante de jusante

- Características do aterro:

Camadas de areão granítico grosseiro com raros Blocos de granito dispersos (Fot. 4).

6 - Características da albufeira, para a cota 341 m (Fig. 7)

- Área inundada $56000 \mathrm{~m}^{2}$

- Volume armazenado $51000 \mathrm{~m}^{3}$

- Desenvolvimento $420 \mathrm{~m}$

\section{B) OUTRAS INFORMAÇÕES}

A ribeira das Paredes na zona da barragem corre entre muros de pedra arrumada, assinalados na Fig. 8. Nesta figura está também representado, na zona da brecha, um muro transversal à ribeira, de pedra arrumada, que terá sido construído para evitar a erosão dos terrenos a jusante, durante a ocorrência de cheias. $\left.{ }^{*}\right)$

(*) Valores estimados a partir dos vestígios. 
O tonónimo presa é utilizado localmente para designar o local da barragem (o caminho que parte da povoação, junto à escola, é o caminho da presa), se bem que as pessoas inquiridas não o associem aos restos da barragem.

Imediatamente a jusante, pode observar-se na margem esquerda uma depressão cuja observação pormenorizada é dificultada pela vegetação, sendo, todavia, reconhecível na fotografia aérea vertical (à escala aproximada de 1:15000), que se reproduz na Fot. 6. Esta depressão pode corresponder à extracção de terras, utilizadas na construção da barragem, parecendo, todavia, mais plausível a hipótese de ser o resultado de exploração mineira.

A existência de água subterrânea na zona, revelada pela abundância de poços e nascentes, torna pouco provável ter sido a barragem construída com a finalidade exclusiva de alimentar a villa localizada a jusante (Fig. 6) ou de fornecer água para rega. O reconhecimento do campo efectuado pelos autores sugere que esta villa, referenciada por SILVA 1979, seria de pequena importância e, por conseguinte, desproporcionada em relação às dimensões da barragem.

A barragem apresenta nítido assoreamento a montante (desnível entre montante e jusante da ordem de $2 \mathrm{~m}$ ).

Sobre os sedimentos da antiga albufeira e a cerca de $80 \mathrm{~m}$ a montante da barragem, pode observar-se uma estrutura hidráulica (Fig. 7; Fot. 7 e 8), construída de blocos graníticos aparelhados. Esta estrutura consta de:

- poço com bocal de planta octogonal parcialmente conservado e uma abertura rectangular ao nível da plataforma;

- tanque escavado num bloco granítico, que provavelmente receberia a água elevada do poço;

- plataforma lajeada.

Do tanque parte um canal que teria conduzido a água para jusante da barragem e que está assinalado na planta da barragem (Fig. 8).

A barragem é seguramente muito anterior à estrutura hidráulica que, pela tipologia do bocal do poço, poderá remontar ao século XV ou XVI.

De facto, a barragem (represa) aparece citada em documento datado de 20 de Setembro de 1505, o Tombo da Comenda de Castelo

Conimbriga, 34 (1995) 75-127 
Novo e Alpedrinha (Ordem de Cristo), transcrito por SILVA 1991, do qual se extrai a seguinte passagem:

e de hi se vay direito aa portella que estaa antre hos maninhos e has Cabeças de Mendralham e da dita portella se mete logo hi na agua do ribeiro das Paredes, e vay pello dicto ribeiro abaixo atee ha Represa que estaa de hi huum quarto de legoa pouco mais ou menos; e de hi vay ainda pello dito ribeiro abaixo atee se meter na ribeira de Taveirol..."

Pelo trecho transcrito, parece concluir-se que a barragem já estaria desactivada naquela data, pois, de contrário, haveria certamente referência à albufeira (opinião, aliás, já expressa por SILVA 1991).

Materiais recolhidos por aquele autor na villa da margem direita, em particular terra sigillata hispânica, bem como um fragmento de vidro de cor verde-gelo, apontam para uma cronologia dos séculos I a II. Nesse mesmo local, foi recolhida (SILVA 1991) uma moeda de bronze de Antonino Pio (138-161 d. C.).

\section{4 - Barragem do Rochoso}

\section{A) CARACTERÍSTICAS PRINCIPAIS}

\section{1 - Localização}

- Coordenadas quilométricas Gauss M =285,7 P = 344,2

- Concelho de Idanha-a-Nova.

- Afluente da ribeira de Monsatela (bacia hidrográfica do Ponsul).

2 - Área da bacia hidrográfica (Fig. 10)

$0,7 \mathrm{~km}^{2}$

3 - Barragem de terra.

4 - Características geométricas iniciais ${ }^{*}$. ss

- Cota do coroamento

- Cota do talvegue $467 \mathrm{~m}$

- Altura máxima (diferença das cotas anteriores)

- Desenvolvimento

- Volume do aterro Impossível de avaliar $\left.{ }^{*}\right)$

(*) Valores estimados a partir dos vestígios. 
5 - Características dos vestígios (Fig. 12 e 13; Fot. 9 e 10)

- Troços de aterro nas duas margens (mais longo o da margem direita, o único praticamente visível - 90 m)

- Largura da brecha

- Declive (V:H) dos paramentos (Perfil A-A, Fig. 13) de montante de jusante

- Características do aterro: Saibro granítico.

6 - Características da albufeira, para a cota 474 m (Fig. 11)

- Área inundada

$8000 \mathrm{~m}^{2}$

- Volume armazenado $10600 \mathrm{~m}^{3}$

- Desenvolvimento

$150 \mathrm{~m}$

\section{B) OUTRAS INFORMAÇÕES}

Esta barragem localiza-se numa área bastante romanizada, destacando-se, a $880 \mathrm{~m}$ a jusante, uma importante villa romana junto à quinta de S. Lourenço.

O padre Ayres Francisco de Proença e Sylva, em nota datada de 20 de Maio de 1758 (in JPBB 1944, p. 45) faz a seguinte descrição da zona envolvente da barragem, sem a esta se referir:

"Ao norte está a Serra chamada da Mouraria, (hoje conhecida pela Serra da Moureirinha e nela existem ainda restos de fortalezas em distância de um quarto de légua, chamada assim por ser habitada de mouros, que para vexarem e combaterem Monsanto principiaram fortalezas cujos vestígios existem. Dela saiem muitas águas, e um aqueduto, por fortíssima cantaria, até S. Lourenço de Monsantel. Deste sítio de S. Lourenço de Monsantel, tem saído centenas de pedras aparelhadas, e ainda ali existem muitas e muitas enterradas."...

Neste local foram efectuadas escavações arqueológicas dirigidas por Maria da Graça Moreira que permitiram descobrir vestígios de uma villa romana, com termas e restos de canalizações (in Conimbriga 1960/61, 2, 3, p. 425). Foram também encontradas sepulturas romanas, algumas com rico espólio, incluindo uma rara bulla de ouro do século I d. C. (ALMEIDA e FERREIRA 1956, 1958). 
Os autores, no reconhecimento de campo efectuado, verificaram que $\mathrm{o}$ aqueduto tinha origem numa fonte provavelmente romana (Fot. 11), localizada a montante da barragem e acima do seu coroamento. Identificaram três troços do aqueduto constituído por caleiras em blocos graníticos aparelhados: um próximo da fonte, outro um pouco a montante da barragem (Fot. 12) e o terceiro a meia distância entre esta e a villa.

Deste modo, é de crer que a água represada pela barragem se destinasse ao regadio, hipótese possível de acordo com a topografia dos terrenos a jusante, ou a apoio da actividade mineira.

A área da bacia hidrográfica no local da barragem do Rochoso é extremamente pequena $\left(0,7 \quad \mathrm{~km}^{2}\right)$ e a sua albufeira encontra-se fortemente assoreada. É, assim, de admitir uma vida útil prolongada para a barragem. $\mathrm{O}$ assoreamento da albufeira justificará a configuração pouco usual do aterro na actualidade, especialmente do talude de montante, com pendente muito suave em parte do seu desenvolvimento.

\section{5 - Barragem da Egitânia}

\section{A) CARACTERÍSTICAS PRINCIPAIS}

1 - Localização

- Coordenadas quilométricas Gauss $\mathrm{M}=283,2 \mathrm{P}=337,9$

- Concelho de Idanha-a-Nova.

- Ribeira de Rio de Moinhos (afluente do Ponsul).

2 - Área da bacia hidrográfica (Fig. 14) $23,9 \mathrm{~km}^{2}$

3 - Barragem de terra.

4 - Características geometricas iniciaio

- Cota do coroamento $295 \mathrm{~m}$

- Cota do talvegue $284 \mathrm{~m}$

- Altura máxima (diferença das cotas anteriores)

- Desenvolvimento $110 \mathrm{~m}$

- Volume do aterro $12000 \mathrm{~m}^{3}$

5 - Características dos vestigios (Fig. 16 e 17; Fot. 13 a 17)

- Troços de aterro nas duas margens (mais longo o da margem direita - $70 \mathrm{~m}$ ).

(*) Valores estimados a partir dos vestigios. 
- Largura da brecha

- Declive (V:H) dos paramentos (Perfil A-A, Fig. 17) de montante de jusante

- Características do aterro:

Matriz argilosa com abundantes elementos de xisto de granulometria muito extensa, podendo atingir $20 \mathrm{~cm}$ (Fot. 16 e 17).

6 - Características da albufeira, para a cota 294 m (Fig. 15)

- Área inundada

$81000 \mathrm{~m}^{2}$

- Volume armazenado

$180000 \mathrm{~m}^{3}$

- Desenvolvimento

$560 \mathrm{~m}$

\section{B) OUTRAS INFORMAÇÕES}

Esta barragem situa-se a cerca de $1500 \mathrm{~m} \mathrm{NW}$ de Idanha-a-Velha, a antiga Egitânia das épocas romana e visigótica.

Trata-se de uma importante estrutura de aterro que terá tido a altura máxima de cerca de $11 \mathrm{~m}$ e dado origem a uma albufeira com volume de armazenamento de $180000 \mathrm{~m} 3$. Subsistem dois troços de aterro separados por uma brecha, na zona do talvegue da ribeira (Fot. 20). Os taludes laterais da brecha são muito abruptos devido à estrutura do aterro, tendo o da margem direita uma altura de cerca de $9 \mathrm{~m}$. Notare, em relação ao reconhecimento efectuado pelos autores em 1985, o acréscimo da erosão deste talude, um pouco acima do talvegue, devido à passagem de cheias, tornando-se necessária intervenção que evite o prosseguimento da erosão.

A observação da sua planta mostra a existência, próximo do arranque direito, de uma depressão que poderia ter correspondido a um descarregador de superfície, de que não há outros vestígios.

Mesmo que não tivesse sido construído expressamente um descarregador de superfície, essa depressão teria funcionado como tal em período anterior ao da abertura da brecha actualmente observável.

A primeira referência à barragem, de que se tem conhecimento, deve-se a Fernando de ALMEIDA 1956. Segundo este arqueólogo, a barragem "serviria para irrigar os campos vizinhos e dar assim melhores possibilidades de vida aos Igeditanos, ou ainda para abastecimento da população". 
Se bem que fosse possível o abastecimento mediante adução por gravidade, como se pode observar na carta topográfica 1:25 000, essa adução teria exigido obras de arte de certo vulto, de que não há quaisquer traços visíveis (QUINTELA et al 1986). Por outro lado, os autores observaram, no adro da torre de menagem de Idanha-a-Velha, trechos de caleira em blocos graníticos (Fot. 18), análogos aos encontrados nas proximidades da barragem do Rochoso e provenientes, segundo informações locais, da área da Horta da Serra, a $880 \mathrm{~m}$ a norte da aldeia, e que poderiam ter pertencido a um sistema de abastecimento de água a Egitânia, a partir de uma nascente.

Esta hipótese parece ser confirmada, pelo seguinte trecho das memórias paroquiais de 1758 (Tomo XVIII, folha 56), in AZEVEDO 1898:

«Ao norte tem a fonte chamada da Serra Obra dos Romanos

cupiosa Agoa e ademiráveis acqueductos que os rusticos tem demullido em grande parte...»

Outra razão justificativa de uma diferente finalidade da barragem relaciona-se com a descoberta de um habitat romano adjacente, localizado numa plataforma da margem esquerda da ribeira (Fot. 19) e que já havia sido referenciado por AlmEIDA 1956 (p. 113). Este autor encontrou naquele local grande quantidade de ladrilhos romanos, fragmentos de tegulae e de tijolo, parte do fundo de um grande vaso, um fragmento de fuste e um pequeno silhar, ambos de granito. Tratar-se-ia de um habitat de artesãos que utilizariam a água para força motriz ou com outra finalidade ou antes de um habitat relacionado com a actividade mineira?

Quanto à hipótese de utilização da água para rega, tal não parece plausível devido à inexistência nas proximidades da barragem, a jusante desta, de solos propícios.

\section{6 - Barragem de Nossa Senhora de Mércoles}

A) CARACTERÍSTICAS PRINCIPAIS

1 - Localização

- Coordenadas quilométricas Gauss $\mathrm{M}=258,3 \mathrm{P}=317,2$

- Concelho de Castelo Branco

- Ribeira da Senhora de Mércoles, subafluente do Ponsul designada por ribeira da Represa (DIAS 1966). 
2 - Área da bacia hidrográfica (Fig. 19)

3 - Barragem de alvenaria \{opus incertum).

4 - Características geométricas iniciais (Fig. 20 e 21; Fot. 21)

- Cota do coroamento $332,6 \mathrm{~m}$

- Cota do talvegue $330,1 \mathrm{~m}$

- Altura màxima (diferença das cotas anteriores)

$2,5 \mathrm{~m}$

- Desenvolvimento $60 \mathrm{~m}$

5 - Características dos vestígios

- Troços nas duas margens (mais longo o da margem direita, $50 \mathrm{~m}$ )

- Largura da brecha $3 \mathrm{~m}$

- Perfil de gravidade, com taludes inclinados a montante e a jusante (Perfil A-A, Fig. 21).

6 - Características da albufeira, para a cota 333 m (Fig. 19)

- Área inundada

$14000 \mathrm{~m}^{2}$

- Volume armazenado

$7200 \mathrm{~m}^{3}$

- Desenvolvimento

$260 \mathrm{~m}$

\section{B) OUTRAS INFORMAÇÕES}

O muro de jusante apresenta aparelho de opus incertum, com altura máxima observável na parte central. O muro de montante apresenta-se de construção idêntica, embora mais dificilmente observável devido à acumulação de sedimentos e à densa cobertura vegetal.

Esta estrutura fora observada anteriormente pelos autores (QUINTELA et al 1986), que verificaram a inexistência de vestígios romanos com ela directamente relacionados. ALMEIDA 1956 sugeriu que o outeiro onde actualmente se localiza o santuário de Nossa Senhora de Mércoles, dominando o vale em que se situa a barragem, pudesse ter servido como local de culto a Mercúrio. Porém, tal hipótese não se baseia em observação segura (GARCIA 1982), não obstante na região serem conhecidos abundantes vestígios romanos (PROENÇA 1905; GARCIA 1979), em particular no triângulo definido pelas ermidas de Senhora de Mércoles, São Martinho e Santana (SALVADO 1980). ${ }^{(*)}$

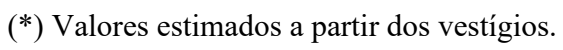


Mesmo confirmando-se tal hipótese, a barragem não se poderia destinar ao abastecimento em água desse local, devido à diferença de cotas. Todavia, a finalidade mais provável da barragem seria a de fornecer água a uma villa localizada algures a jusante, ou para apoio a actividades mineiras.

\section{7 - Barragem de Monforte}

\section{A) CARACTERÍSTICAS PRINCIPAIS}

1 - Localização

- Coordenadas quilométricas Gauss $\mathrm{M}=264,4 \mathrm{P}=308,4$

- Concelho de Castelo Branco

- Afluente da ribeira da Farroupinha (afluente do Ponsul).

2 - Área da bacia hidrográfica (Fig. 22).

$4,8 \mathrm{~km}^{2}$

3 - Barragem de terra.

4 - Características geométricas iniciais

- Altura máxima (aproximada)

- Desenvolvimento

5 - Características geométricas dos vestígios (Fot. 22)

- Troço de aterro na margem direita

- Largura da brecha $20 \mathrm{~m}$

- Características do aterro:

Matriz argilo-arenosa com calhaus rolados

B) OUTRAS INFORMAÇÕES

Esta barragem foi localizada pelos investigadores locais $\mathrm{F}$. Henriques e J. Caninas (HENRIQUES et al 1990) e reconhecida pelos autores em 1990.

Os investigadores que a localizaram designaram-na por barragem do Represão, o que se terá devido à existência do curso de água Vale do Represão, que conflui com outro um pouco a montante do local da barragem. $\left.{ }^{*}\right)$

(*) Valores estimados a partir do reconhecimento dos vestígios (não foram obtidos levantamentos topográficos da barragem nem da albufeira). 
A designação de barragem de Monforte substitui a de Represão, termo que se refere a uma estrutura pós-romana, constituída por blocos de xisto, localizada cerca de $600 \mathrm{~m}$ a montante.

Procuraram-se informações sobre os antecedentes da barragem junto da família Almeida Garrett, proprietária do Monte da Represa situado nas proximidades. Na documentação dessa família, não há referência à barragem, até porque é relativamente recente a posse daquele monte na família (há cerca de 80 anos). Obteve-se a informação de que "existem vestígios de mineração nas proximidades do monte, o que leva a admitir ter a represa sido construída pelos Romanos para utilizar a água no tratamento de minério. Não foram, porém, encontrados na zona vestígios de habitats romanos, nem de restos de cerâmica". Adicionalmente, obteve-se a informação de que os vestígios de mineração correspondem a escórias. Admite-se que estas estejam relacionadas com forjas para fabrico e reparação de utensílios agrícolas.

Não há referências bibliográficas a villae nas proximidades desta barragem. Porém, foram achadas na freguesia de Monforte da Beira várias xorcas de prata e uma de ouro, as primeiras associadas a denários (VASCONCELOS 1920, p. 104). Outro tesouro encontrado na zona de Monforte da Beira era constituído por mais de 800 denários republicanos (PROENÇA 1910, citado por ALARCÃO 1988 b).

\section{8 - Barragem da Lameira}

\section{A) CARACTERÍSTICAS PRINCIPAIS}

\section{1 - Localização}

- Coordenadas quilométricas Gauss $\mathrm{M}=249,8 \mathrm{P}=302,5$

- Concelho de Vila Velha de Ródão.

- Ribeira do Ribeirão, afluente do rio Tejo.

2 - Área da bacia hidrográfica (Fig. 23)

3 - Barragem de terrra.

4 - Características geométricas iniciais ‘

- Cota do coroamento

- Cota do talvegue $172 \mathrm{~m}$

- Altura máxima (diferença das cotas anteriores)

(*) Valores estimados a partir dos vestígios. 
- Desenvolvimento

- Volume do aterro

5 - Características dos vestígios (Fig. 25 e 26; Fot.23 a 25)

- Troços de aterro nas duas margens (mais longo o da margem direita).

- Largura da brecha na base

- Declive (V:H) dos paramentos (Perfil A-A, Fig. 26) de montante de jusante

- Características do aterro:

Matriz argilo-arenosa com blocos de xistos e grauvaques, mal rolados e mal calibrados.

6 - Características da albufeira, para a cota 180 m (Fig. 24)

- Área inundada $353000 \mathrm{~m}^{2}$

- Volume armazenado $840000 \mathrm{~m}^{3}$

- Desenvolvimento

- Volume do aterro $16000 \mathrm{~m}^{3}$

\section{B) OUTRAS INFORMAÇÕES}

Esta barragem foi localizada pelos investigadores locais F. Henriques e J. Caninas e A. Henriques e reconhecida pelos autores em 1985 (HeNRIQUEs et al 1985; QuíNTELA étal 1986).

Trata-se de uma barragem de aterro, cuja estrutura se pode observar na secção executada recentemente junto do talvegue da ribeira do Ribeirão, com vista à passagem da água em situação de cheia, provavelmente onde existia uma brecha no aterro. Sobre o aterro existem numerosas azinheiras de grande porte.

Devido à largura do vale, a barragem apresenta grande desenvolvimento que excede largamente o das outras barragens de terra estudadas neste trabalho. O seu traçado singular, constituído por três troços rectilíneos, foi condicionado pela necessidade de adaptação à topografia do vale.

Para montante, espraia-se a área da antiga albufeira, vasta e denotando pouco assoreamento e onde se observam, próximo da barragem, duas noras antigas.

Um agricultor do local, nascido em 1905, informou não ter ouvido qualquer referência ao represamento de água pela barragem. Para 
jusante, o vale é apertado e os terrenos não têm aptidão agrícola. Por outro lado, não se identificaram até ao presente estações romanas nas proximidades que pudessem ter beneficiado da água represada.

Os dois habitats romanos mais próximos até agora identificados localizam-se para montante da barragem, a $3 \mathrm{~km}$ a norte e 2,6 km a noroeste (Fig. 23), segundo informações prestadas pelos investigadores locais F. Henriques e J. Caninas. Pode, pois, aceitar-se que a barragem estivesse relacionada com a actividade mineira. Em reforço desta hipótese, cita-se o achado de uma xorca de prata e de fragmento de outra (semelhantes às de Monsanto e de Monforte), peças conservadas no Museu Nacional de Arqueologia (VASCONCELLOS 1920, p. 104).

\section{9 - Barragem do Souto do Penedo}

A barragem de Souto do Penedo situa-se a cerca de $2 \mathrm{~km} \mathrm{SE} \mathrm{de}$ Vila de Rei, na ribeira do Pisão (subafluente do Zêzere) num local com as seguintes coordenadas quilométricas Gauss: $\mathrm{M}=200,3 ; \mathrm{P}=299,4$. A área da bacia hidrográfica é de $5,3 \mathrm{~km}^{2}$ (Fig. 27).

Não foram obtidas para este trabalho as plantas do local da barragem e da albufeira, pelo que não é possível apresentar a correspondente ficha descritiva.

Segundo informação localmente obtida, teria tido lugar, nos anos setenta, derrube de um grande troço do muro da barragem para a construção de um pontão da nova estrada, de Abrantes a Vila do Rei.

A única referência que se conhece desta obra é de FÉLIX 1985 (p.47). Este autor refere-se a uma importante represa no "penedo do Souto do Penedo", seguindo hipoteticamente a água a partir deste local, através de um aqueduto, para a região de Milreu e talvez da Lousa e Cabecinha. Na sua opinião, a "Lomba das Torres" deve o nome às torres ou pilares do velho aqueduto». No reconhecimento efectuado não se identificaram, todavia, quaisquer vestígios desta obra. FÉLIX 1985 refere ainda a existência de outras represas que estariam relacionadas com explorações mineiras, nos ribeiros da Quinta das Laranjeiras, na de Codes, na de Souto e a outros aquedutos não especificados, o que o reconhecimento realizado pelos autores não confirmou.

É provável que, na realidade, a finalidade da barragem estivesse relacionada com a mineração, não só pela inexistência de so- 
los a jusante para regadio (declives muito acentuados), mas também devido aos inúmeros vestígios de antiga actividade mineira existentes na zona.

A barragem situou-se numa zona do vale que se apresenta estrangulada em consequência de um grande afloramento granítico na margem esquerda da ribeira, que deu origem à designação toponímica "Souto do Penedo".

0 afloramento apresenta uma escarpa do lado da ribeira, a qual teria constituído o encontro esquerdo da barragem. Desta apenas restam dois curtos troços de opus incertum, um situado no topo do Penedo, junto à escarpa (Fot. 26), e outro colmatando uma pequena brecha no rochedo com cerca de $2 \mathrm{~m}$ de altura.

\subsection{0 - Barragem de Alferrarede}

\section{A) CARACTERÍSTICAS PRINCIPAIS}

1 - Localização

- Coordenadas quilométricas Gauss $\mathrm{M}=196,4 \mathrm{P}=280,0$

- Concelho de Abrantes (distrito de Santarém)

- Ribeira de Alferrarede, afluente do rio Tejo.

2 - Área da bacia hidrográfica (Fig. 28)

3 - Barragem de alvenaria (duplo muro com aterro intermédio).

4 - Características actuáis (Fig. 29 a 31; Fot. 27 a 33).

- Cota do coroamento $52,62 \mathrm{~m}$

- Cota do talvegue $39,11 \mathrm{~m}$

- Altura máxima (diferençatías cotas anteriores)

- Desenvolvimento

5 - Características da albufeira, para a cota $52 \mathrm{~m}$ (Fig. 29)

- Área inundada

$88000 \mathrm{~m}^{2}$

- Volume armazenado $147000 \mathrm{~m}^{3}$

- Desenvolvimento $700 \mathrm{~m}$

B) OUTRAS INFORMAÇÕES

Na Carta Militar de Portugal, à escala de 1/25 000, esta estrutura encontra-se designada por "Ponte dos Mouros". Embora tenha servido de ponte (mais propriamente ponte-represa), a sua atribuição ao 
período de dominação árabe revela, apenas, uma conhecida tradição arreigada no imaginário colectivo.

Uma das primeiras obras que lhe faz referência deve-se a Diogo OLEIRO 1952, da qual se transcrevem os seguintes trechos (p. 289):

“...Da sua antiguidade, solidez e estilo deduziram os arqueólogos que os filhos do Islão a utilizavam, simultáneamente, como ponte e como barragem para irrigar os terrenos marginais".

E toda construída de pedra e acha-se muito bem conservada, a despeito da sua remota origem. O leito do rio e as margens são de rocha.

A consulta do tombo de Manoel Estevão de Almeida Vasconcellos Rebelo Quifel Barberino, antepassado dos actuais proprietários da Quinta do Bom Sucesso, com data de 1887, apenas revelou referências isoladas do "Alto da Repreza da Agoa".

Trata-se de uma estrutura constituída por um duplo muro, de alvenaria, com aterro intermédio. Tal tipologia é comum a barragens que durante o período filipino foram construídas em Espanha.

A barragem de Alferrarede tem a altura máxima de $13,5 \mathrm{~m}$, o comprimento de $55 \mathrm{~m}$ e a espessura de $11 \mathrm{~m}$. Junto do encontro esquerdo, do lado de jusante, observa-se um contraforte, com cerca de $1,5 \mathrm{~m}$ de comprimento e $1,0 \mathrm{~m}$ de espessura. Entre este e o talude daquele encontro, situa-se uma galeria que atravessa, perpendicularmente, quase todo o corpo da barragem, sem que a sua função esteja completamente determinada - Fot. 30. A abertura desta galeria no paramento de montante aparenta ter sido obturada, pelo que anteriormente a galeria poderia ter funcionado como descarregador de cheias.

Os muros de montante e de jusante, com uma espessura média de cerca de 2,00 m, apresentam-se constituídos de alvenaria de blocos arrumados, cuja argamassa não revela as características habituais das suas congéneres romanas.

O muro de montante é revestido no seu paramento aparente por blocos mais ou menos regulares com as juntas refechadas com argamassa que contém elementos de cerâmica obtidos por moagem, à semelhança do opus signinum romano. A utilização deste tipo de argamassa em obras pós-romanas não é frequente.

Os muros extremos da estrutura da barragem ultrapassam em altura o caminho de terra batida (daí o nome de ponte) que percorre o coroamento da barragem e corresponde ao enchimento intermédio em 
aterro e servem, assim, de guarda àquele caminho. Junto do encontro da margem direita e encostado ao muro de jusante, situa-se um tanque ao qual se ligam duas caleiras que se prolongam pela margem esquerda - Fot. 32.

A água passa para jusante através de um rombo aberto na base da barragem, com os bordos superiores, a montante e a jusante, cobertos por água. Não há qualquer vestígio de guias para instalação de uma comporta, se se tratasse de uma descarga de fundo.

A planta topográfica da albufeira - Fig. 29 - e as Fot. 32 e 33 mostram assoreamento muito importante, com uma espessura que se poderá estimar em cerca de $4 \mathrm{~m}$, sobre o terreno marginal a montante da barragem. O efeito da passagem da água pelo rombo na base da barragem é evidenciado na Fig. 29, pela superfície cónica dos sedimentos junto ao rombo.

Para a realização dos levantamentos topográficos, a DirecçãoGeral dos Recursos Naturais promoveu, em 1988, uma operação de desmatação; figueiras, outras árvores e arbustos, nomeadamente silvas, impediam o reconhecimento - Fot. 27. Passados quatro anos, a vegetação voltou a crescer, impedindo novo reconhecimento.

A relativa modernidade desta construção foi reforçada pela descoberta, pelos autores, acompanhados por J. Candeias da Silva, em Abril de 1988, de restos de uma estrutura romana que antecedeu a barragem, no mesmo local. Trata-se de um muro de opus signinum, de cerca de $5 \mathrm{~m}$ de comprimento, desviado da vertical, situado na margem esquerda, a montante, mas sugerindo ter possuído idêntico desenvolvimento ao da estrutura actual. Este muro está assinalado na planta da barragem (Fig. 30); vestígio análogo, mas de menor comprimento, encontra-se na margem direita - Fot. 28 e 29.

Julga-se, pois, demonstrada a origem romana da "ponte represa" de Alferrarede, aliás já suspeitada por J. Candeias da SILVA, 1986, quando afirmava: "em face da descoberta de uma "nova" estação romana a jusante, hipotética villa, era possível que os fundamentos da chamada ponte-represa fossem mesmo romanos".

Se a finalidade dessa primitiva estrutura se poderia relacionar com o abastecimento à referida villa, localizada a $850 \mathrm{~m}$, a sul, (não obstante o volume de armazenamento da albufeira, de $147000 \mathrm{~m}^{\wedge}$, parecer excessivo para o efeito) já a da construção moderna que actualmente ali se encontra é mais problemática. Deveria servir essencialmente, à semelhança de outras congéneres hispânicas do período filipino, para produção de força motriz, como sugere a existência de restos de um 
moinho de roda horizontal encostado ao muro de jusante (lado direito do talvegue). Serviria ainda para a rega dos campos, se bem que talvez não tivesse sido esse o objectivo primordial da sua construção.

\subsection{1 - Presa de Penamacor}

A barragem (Presa) de Penamacor situar-se-ia a cerca de $5 \mathrm{~km} \mathrm{NE}$ de Penamacor, na ribeira da Presa (subafluente do Erges), num local suposto com as seguintes coordenadas quilométricas Gauss: $\mathrm{M}=359,2$; $\mathrm{P}=286,1$.

Nas cercanias indicadas da carreira de tiro da guarnição militar de Penamacor podem observar-se duas grandes sanjas mineiras, muito provavelmente de origem romana: a Corta da Presa e o Covão do Urso. Estas sanjas fizeram parte de um prédio rústico denominado "Couto da Arrancada e Monsanta" tal como se deprende da doação feita ao Ministério da Guerra, em 4/12/1903, no Cartório Notarial de Penamacor, dos terrenos para a instalação da Carreira de Tiro e suas dependências (LOBATO 1982).

Têm sido numerosos os traços da presença romana encontrados até agora nos terrenos deste antigo couto. Num local sobranceiro à ribeira da Bazaguedinha encontraram-se nos anos trinta "pedestais de coluna, bocados de fustes e capitéis de granito" de provável origem romana. Na serra de "Monsanta", contígua à Carreira de Tiro, foi encontrado, em 1948, um tesouro monetário romano, constituído por denários consulares, tendo também o Padre João Lobato recolhido naquela zona "fragmentos de tégula, de tijoleiras, de atafonas, de urnas funerárias e de colunas" (LOBATO 1982, p. 165).

Segundo José Manuel LANDEIRO (1938, p. 170-173), o primeiro "dono ou senhor" do Lago da Presa foi Salvador Taborda Negreiros (1584-1626). Indica-se no Título Geneológico da Lamília Taborda que, no tempo deste proprietário, o lago rebentou. Aquele autor menciona que, de acordo com a tradição lendária, "o lago necessitava, de quando em quando, ser sangrado, caso contrário rebentaria. Para isso, havia um encarregado para proceder a essa operação. Sucedeu, porém, que num dia de festa, em Penamacor, o sangrador se demorou na vila. O lago rebentou e a detonação foi ouvida na vila! " (idem, p. 171).

Landeiro menciona que, de acordo com o Título Geneológico da Lamília Taborda, o lago seria "mais de divertimento do que de interesse, porque muitas vezes, se tentou tapar o lago para fazerem 
engenhos e moendas. O lago ficava a meia légua do sítio da Carreira de Tiro, onde ainda se podem admirar os seus restos. Tinha de comprimento cerca de meia légua".

De acordo, ainda, com Landeiro 1938, o Dr. Francisco Taborda Negreiros, proprietário do Lago a partir de 1711, fez grandes despesas na Presa, havendo conduzido para ali pedras que mandou lavrar e tendo mandado vir do Alentejo mais de sessenta moios de cal. O mesmo autor refere um manuscrito datado de 1885, da autoria do Dr. Adelino Galhardo, em que se encontra escrito que no Lago da Presa, ainda nesse ano, se encontrava grande porção de cal soterrada, provavelmente restos da que mandou vir o Dr. Francisco Taborda. José Manuel LANDEIRO (1938, p. 173) afirma ainda que o lago desapareceu "mas ainda se pode admirar os Covões do Urso, que faziam parte do referido lago".

A Presa aparece também citada em 1758 pelo Pároco de Santa Maria de Penamacor, no Dicionário Geográfico, do seguinte modo: "na distância de meia légua, para a parte nordeste está entre colmados montes um grande lago chamado a Presa, que conserva abundantes águas em todo o tempo, mas sem especial qualidade". Diz ainda que "Antigamente estava tapado com forte muro de alvenaria, ser-viam-se das suas águas os engenhos de Pisões, Moinhos e Cubos; porém rebentando a parede que suspendia as águas, com o peso delas alagou todos os engenhos de que ficaram alguns alicerces" (in LOBATO 1982, p. 168).

Várias questões suscitam as informações contidas na documentação citada (Dicionário Geográfico e Título Genealógico da Família Taborda). Na primeira obra indica-se que a Presa se situa a meia légua de Penamacor para NE. Na segunda, que o lago ficava a meia légua do sítio da Carreira de Tiro. Uma vez que uma légua são cerca de $5 \mathrm{~km}$, nunca tal localização poderá coincidir com o topónimo "Presa" da Carta Militar de Portugal (folha 248), onde se situa efectivamente uma grande corta ou sanja mineira. Por outro lado, os Covões do Urso referidos por J. M. Landeiro e representados naquela carta militar não só se encontram a uma cota muito superior à da ribeira para onde drenam, como se encontram a cerca de $500 \mathrm{~m}$ da Carreira de Tiro.

Finalmente, há que referir ser muito pouco provável que a citada Presa tivesse sido de feitura romana devendo, na realidade, ter sido construída por Salvador Taborda Negreiros em inícios do século XVII, considerado o primeiro "dono ou senhor" do Lago. 
Nenhuma referência existe a qualquer barragem pré-existente a esta última, se bem que as cortas actualmente visíveis sejam prova evidente de grande actividade mineira a céu aberto, em épocas remotas.

Segundo LOBATO 1982 (p. 172), "um dos caprichosos montões de terra que ficaram para "modelo" na Corta Grande conserva ainda o nome de "Cabeço da Mina".

De acordo com os elementos recolhidos, é de concluir:

- a barragem designada por "Presa” terá sido construída no início do século XVII;

- existem discrepâncias sobre a sua localização exacta segundo os testemunhos constantes das diferentes fontes consultadas.

No decurso dos reconhecimentos aerofotogràfico e de terreno, efectuados pelos autores deste estudo, não se encontrou qualquer traço da referida barragem.

\section{5 - ASPECTOS RELEVANTES DAS BARRAGENS ESTUDADAS}

\section{1 - Barragens romanas de aterro}

\subsection{1 -Barragens de aterro pré-romanas e romanas doutras regiões}

Para enquadrar os aspectos relevantes das barragens romanas de terra do distrito de Castelo Branco, apresentam-se exemplos característicos de barragens de aterro (de terra e de enrocamento) pré-romanas e romanas e ainda de outras barragens antigas notáveis.

Tais exemplos são extraídos sobretudo do estudo da evolução de barragens de aterro até à actualidade, de que é autor SCHNITTER 1988.

A construção de barragens de aterro iniciou-se no Médio Oriente há cerca de 5000 anos.

Está bem documentada a barragem de Jawa (construída cerca de 3000 anos a. C.) destinada a criar uma albufeira para alimentar de água a cidade do deserto de Jawa, cerca de $100 \mathrm{~km}$ a nordeste de Amman, na Jordânia. Trata-se de uma estrutura de aterro, complexa, com um núcleo central constituído por duplo muro de alvenaria com aterro intermédio, a qual, após alteamento, atingiu a altura de $5,5 \mathrm{~m}$ e a largura máxima na base de $23 \mathrm{~m}$. 
Merece referência especial a barragem de Kaffara (2600 a. C.), num pequeno afluente do Nilo, destinada a proteger um porto no Nilo das cheias desse afluente. Era constituída por um núcleo sobredimensionado, de areia siltosa e seixo, e por maciços laterais de enrocamento com o paramento de jusante revestido de blocos de pedra aparelhados. Tinha a altura máxima de $14 \mathrm{~m}$ e foi destruída por galgamento durante a construção.

A barragem de Kofini (1300 a. C.), na Grécia, tinha como objectivo desviar a água das cheias a fim de proteger a cidade micènica de Tirinto. Estando ainda intacta, o seu perfil interno não é conhecido, mas a excessiva largura da barragem na base (cerca de 6 a 10 vezes a altura máxima de $10 \mathrm{~m}$ ) leva a supor ter perfil homogéneo.

A barragem de Marib serviu para a rega do norte do Iémen entre o século VI a. C. e o século VII d. C. Os vestígios levam a admitir tratar-se de uma barragem de terra de perfil homogéneo, que, no seu estádio final, atingiu $20 \mathrm{~m}$ de altura e $680 \mathrm{~m}$ de desenvolvimento.

Com vida longa, comparável à barragem de Marib, foi construída antes desta, no México, a de Puron, a qual, ao longo de 1800 anos, sofreu sucessivos alteamentos, para alturas de 3, 7, 10, 18 e $19 \mathrm{~m}$. Dois desses alteamentos foram obtidos por meio de células de alvenaria cheias de solo arenoso compactado. No estádio final atingiu a altura de $9 \mathrm{~m}$ e a largura na base de $105 \mathrm{~m}$.

$\mathrm{Na}$ mesma época teve lugar a construção de barragens de aterro noutras regiões. Por exemplo no Sri Lanka, entre 380 a. C. e 80 d. C. foram construídas barragens de terra de perfil homogéneo com desenvolvimentos excepcionais, com o máximo de 8,6 km. Estas barragens eram dotadas de descarregadores e de notáveis estruturas para permitir a saída da água, constituídas por condutas e por poços para instalação de comportas, situados no paramento de montante da barragem.

A barragem mais alta do Sri Lanka tinha a altura de $17 \mathrm{~m}$ (foi alteada com mais $17 \mathrm{~m}$ no ano $460 \mathrm{~d}$. C.).

Embora desde muito cedo tenham sido construídas barragens na China, só se encontraram vestígios importantes das construções realizadas a partir do século III a. C. As mais antigas barragens de terra chinesas, com importância, são as de Qianlubei e Marenbei (48 a 32 a.C.) - LIANDI 1991.

A barragem de Marenbei, com cerca de $15 \mathrm{~m}$ de altura e $820 \mathrm{~m}$ de desenvolvimento, era de perfil homogéneo, de solo argiloso. Era dotada de descargas para saída da água e de descarregador de superfície. 
Pouco posterior à época romana é a importante barragem de Fushan, de terra, de que há registos escritos e vestígios de dois troços (LIANDI 1991).

A barragem, situada no rio Huai, $150 \mathrm{~km}$ a norte de Nanging, teria a altura aproximada de $30 \mathrm{~m}$, o volume de aterro de $2 \times 10^{6} \mathrm{~m}^{3}$ e criaria uma albufeira de $10000 \times 10^{6} \mathrm{~m}^{3}$.

A sua finalidade era bélica: a de inundar a povoação de Shouyan, a montante, para desalojar a sua forte guarnição militar.

$\mathrm{O}$ fechamento do rio foi tentado, sem êxito, no ano de 514 d.C. e conseguido no ano seguinte pelo lançamento de caixas de pedra, de dezenas de milhares de toneladas de ferro e outros materiais.

A barragem tinha dois descarregadores de superfície, um com 70 a $80 \mathrm{~m}$ de largura e $10 \mathrm{~m}$ de profundidade. Não obstante, a barragem foi galgada no ano da conclusão (515 d. C.), tendo deixado escoar rapidamente o volume de $10000 \times 10^{6} \mathrm{~m}^{3}$, o que deu origem a um ruído que «troava como trovão e podia ser ouvido a $150 \mathrm{~km}$ de distância» e provocou severos danos a mais de 10000 habitantes a jusante.

Os Romanos construíram, de preferência, barragens constituídas por muros, muito frequentemente reforçados por contrafortes. SCHNITTER 1988 afirma que os Romanos nas suas poucas barragens de terra sempre introduziram um elemento de alvenaria, frequentemente um muro de retenção de água a montante.

Exemplos deste tipo de solução são as importantes barragens de Alcantarilla e Proserpina em Espanha. Nesta última barragem, o muro a montante do aterro é reforçado por contrafortes, para montante, com a finalidade de obstar ao derrube no caso de esvaziamento, devido à pressão da água instalada no aterro (Fot. 34). Uma variante àquela solução é a barragem de Cornalbo, também em Espanha; em vez de muro a montante, são utilizadas células de alvenaria inseridas na parte de montante do aterro. Estas três barragens destinavam-se ao abastecimento populacional e estão ainda em funcionamento, embora, com outra finalidade, a rega.

A afirmação de Schnitter anteriormente citada está em contradição com a notícia de VITA-FINZI 1961 (in QUINTELA et al 1986) de barragens de terra construídas pelos Romanos em vales largos na Tripolitânia (Líbia). Tais barragens eram providas, nos dois extremos, de descarregadores de superfície, de alvenaria, que constituem os únicos vestígios dessas barragens. Aquela afirmação de Schnitter é também contrariada por referências mais recentes a barragens romanas de terra. 
É o caso das barragens de Sergiopolis, na Síria, de Lostugun, na Anatolia,e das barragens da zona mineira de Rosia Montana (Roménia).

A barragem de Sergiopolis, de perfil trapezoidal e altura actual de $1,7 \mathrm{~m}$ e com a base do lado de montante protegida por enrocamento, destinava-se a promover a entrada de água do rio para o canal de alimentação das cisternas que abasteciam a cidade de Sergiopolis, actualmente Resafa (CALVET e GeYER, 1992; GARBRECHT 1991b, p. 248).

A barragem de terra de Lostugun na Anatolia, tem a altura de $12 \mathrm{~m}$, a largura no coroamento de $20 \mathrm{~m}$ e destinava-se à rega (GARBRECHT 1991a). Situava-se numa zona em que o rio se divide em dois braços separados por um maciço calcário. A barragem era constituída por duas partes (com 60 e $70 \mathrm{~m}$ de desenvolvimento), estando muito bem conservada a parte direita e destruída a parte esquerda. Era provida de um descarregador de cheias em túnel horizontal,de 1,50 $\mathrm{m}^{2}$ de secção, escavado no maciço calcário. GARBRECHT (idem, p. 98) sublinha que considerar-se esta barragem como construída na Antiguidade Tardia é mais suposição do que certeza.

Segundo BOTZAN et al 1991, conservam-se, ainda hoje, na região de Rosia Montana (Roménia) seis barragens de terra originariamente construídas pelos Dácios, que utilizavam a água das respectivas albufeiras para a lavagem de minério aurífero. As barragens represam água na actualidade, devendo-se a sua boa conservação aos restauros promovidos pelas populações que sucessivamente procederam à exploração de ouro na região, entre as quais os Romanos.

Regista-se que relevos do forum de Trajano, em Roma, representam a retirada de ouro e prata da Dàcia. Segundo BOTZAN et alii 1991, investigações recentes permitem supor que Trajano retirou da Dàcia $150 \mathrm{t}$ de ouro e $300 \mathrm{t}$ de prata, com o que financiou obras sumptuosas. Este imperador retomou a exploração das minas de Alburnus Maior (hoje Rosia Montana).

BOTZAN et alii descrevem as barragens de terra de Mare, Tzarinei, Corna, Brasilor, Anghe e Silistea. A barragem de Mare é a de maior altura $(25 \mathrm{~m})$ e a sua albufeira a de maior capacidade $\left(160000 \mathrm{~m}^{3}\right)$. E interessante notar que estas barragens foram construídas numa região com precipitação anual média de $780 \mathrm{~mm}$, que se não afasta da correspondente à região das barragens estudadas neste trabalho.

Assinala-se que se não encontra justificação para os perfis transversais que algumas destas barragens apresentam. E o caso dos 
paramentos de montante com grandes declives 1:1, 2:1 e 3:1 (V:H), que parecem dever comprometer a establidade da barragem em caso de esvaziamento da albufeira. Também se apresenta anómalo o perfil transversal da barragem de Mare: com a impermeabilização a jusante, por meio de revestimento do paramento de jusante por um muro de alvenaria, apoiado em três contrafortes.

E referida a existência actual de descarga de fundo nas barragens de Mare, Tzarinei, Corna e de descarregador de superfície nessas barragens e na de Brasilor.

Para a barragem de Tzarinei é referido expressamente que aqueles órgãos foram construídos em 1749. A construção das descargas de fundo será muito provavelmente pós-romana também nos outros casos e, seguramente, no caso da barragem de Corna em que o tubo da descarga de fundo é de aço.

Aliás, depois da descrição individual das barragens, BOTZAN et al 1991 referem que "Embora as barragens da região de Rosia Montana tinham adquirido o actual aspecto na segunda metade do século XVIII, não se deve esquecer que sua origem se situa cerca da data do nascimento de Cristo".

Do que foi dito relativamente à escassez de barragens comprovadamente romanas exclusivamente de terra, pode concluir-se da importância das barragens romanas do distrito de Castelo Branco.

E interessante assinalar que na Ásia, nomeadamente no Japão, Sri Lanka, China e índia, se continuaram a construir, durante a Idade Média (europeia), importantes barragens de aterro, muitas de perfil homogéneo, algumas com altura superior a $30 \mathrm{~m}$ (SCHNITTER 1988).

Por seu turno, na Europa, foi necessário que decorresse quase um milénio após a época romana para se retomar a construção de barragens que promovessem a criação de albufeiras, ainda que barragens de derivação tenham sido frequentemente construídas. Fazem excepção, na Idade Média, barragens de alvenaria, construídas em Espanha, de que se destacam as barragens de Almansa (1384) e Almonacid de Cuba (anterior a 1431) e pequenas barragens de terra construídas em várias partes da Europa, para rega, piscicultura e accionamento de rodas hidráulicas (ORDONEZ 1984, p. 12; SCHNITTER 1988, p. 29). 


\subsection{2 - Tipologia das barragens de terra estudadas}

Das seis barragens romanas de terra estudadas no distrito de Castelo Branco, as de Egitânia, Lameira e Orca são as que possuem o conjunto de características mais notáveis

\begin{tabular}{|l|r|r|r|}
\hline \multicolumn{1}{|c|}{ Características } & Egitânia & Lameira & Orca \\
\hline Altura (m) & $\mathrm{H}$ & 8 & 6 \\
Desenvolvimento (m) & 110 & 380 & 145 \\
Volume de aterro $\left(\mathrm{m}^{3}\right)$ & 12000 & 16000 & 8700 \\
Volume da albufeira $\left(\mathrm{m}^{3}\right)$ & 180000 & 840000 & 51000 \\
\hline
\end{tabular}

Segundo as indicações disponíveis e como mais pormenorizadamente será analisado na alínea 6.3, serão confirmadamente romanas as da Egitânia e da Orca, acabadas de mencionar, e as da Lajinha e do Rochoso, havendo menor evidência nesse sentido quanto à da Lameira e, sobretudo, à de Monforte.

As barragens de aterro estudadas têm traçado em planta rectilínea, salvo a da Lameira, com traçado poligonal, devido ao seu maior desenvolvimento $(380 \mathrm{~m})$ e à necessidade de adaptação à topografia.

Os taludes dos paramentos têm declives variáveis, em geral, mais suave $o$ de montante, podendo o de jusante apresentar-se bastante áspero (relação entre comprimentos na vertical e na horizontal de 1: 1,7 a 1: 1,1 - Fig. 32) como no caso das barragens da Lajinha, Orca e Egitânia, o que poderá dever-se à erosão pluvial.

As barragens apresentam brechas na zona do talvegue que evitaram a destruição dos troços restantes pela acção das cheias.

Não foram encontrados vestígios de descarregadores de superfície e de descargas de fundo.

O aterro, cuja estrutura está aparente nos taludes das brechas, é sensivelmente homogéneo, embora a sua constituição seja diferente em várias barragens, em consequência das diferentes características dos solos localmente disponíveis.

Assim, é essencialmente constituído por saibros graníticos (Lajinha, Orca e Rochoso), por matriz argilosa com calhaus rolados (Monforte) e por matriz argilo-arenosa com elementos de xisto de 
dimensões variáveis (Egitânia) ou com blocos rolados de xisto e grau vaque (Lameira).

$\mathrm{Na}$ barragem da Egitânia, o aterro, de matriz argilosa, apresenta, nas zonas em que os elementos de xisto são de pequena dimensão, e de forma lamelar, forte coesão.

Revela, assim, uma boa técnica de execução, com adequadas condições de adição de água e de compactação.

Poderia dizer-se que, de certo modo, foi exemplo percursor da técnica da utilização de xistos no aterro de barragens, que o Laboratório Nacional de Engenharia Civil veio a desenvolver nos anos sessenta.

Assim se explica que o talude de jusante, que está desnudado de vegetação, apresente um talude de $1: 1,1$, sem se notarem vestígios de erosão acelerada.

Os taludes das barragens estão, em geral, defendidos da erosão por vegetação variada, desde a de pequeno porte (vegetação herbácea e arbustiva) a árvores.

\section{2 - Barragens romanas de alvenaria}

As barragens romanas de alvenaria estudadas nesta obra são a de Nossa Senhora de Mércoles e a do Souto do Penedo, esta com vestígios muito escassos, mas que permitem supor ter tido altura superior a $10 \mathrm{~m}$.

A barragem de Nossa Senhora de Mércoles está mal conservada, é de pequena altura e não tem aspectos relevantes que se comparem com as de algumas das barragens romanas de alvenaria reconhecidas em Portugal a sul do Tejo.

\section{3 - Barragem de Alferrarede}

Os aspectos mais relevantes da barragem de Alferrarede são a sua estrutura, de duplo muro de alvenaria com aterro intermédio, relativamente em bom estado de conservação, altura de $13,5 \mathrm{~m}$ e considerável volume da albufeira, de $147000 \mathrm{~m}^{3}$. Esta barragem, que também serve de ponte (ponte-represa), tem analogias com a barragem da Represa (Gavião), cujos muros estão desmoronados na sua maior parte e de que não restam vestígios do aterro (QUINTELA et al 1986, p. 108-112).

Dada as analogias dessas duas barragens com as de Madrid e de Antígola, mandadas construir por Filipe II de Espanha, não é de excluir 
que datem dessa época, podendo terem sido seus autores engenheiros hidráulicos célebres que Filipe II fez deslocar a Portugal, como Juan Bautista Antonelli e Leonardo Turriano (QuínTela et al 1986, p. 34 35, 108-112). Trata-se de hipótese que carece de ser comprovada por estudo arqueológico e documental; no entanto, foi aceite, com as devidas reservas por GARCIA TAPIA 1985.

\section{6 - OCUPAÇÃO ROMANA DA REGIÃO}

\section{1 - Território e rede viària}

A área do estudo localiza-se no território da província romana da Lusitânia, criada por Augusto, que teve como capital Colonia Augusta Emérita (ou Colonia Iulia Augusta Emérita), a actual cidade de Mérida.

J. ALARCÃO 1988a apresenta uma descrição sucinta do que terá sido a reorganização administrativa do território português efectuada no tempo daquele imperador, que terá consistido não só na criação da província da Lusitânia, mas também na fundação de novos centros urbanos, na urbanização de oppida pré-existentes e na delimitação dos territoria das diferentes civitates. A inscrição da ponte de Alcântara menciona onze dessas civitates, uma das quais se refere aos Igaeditani, que tiveram a sua capital em Egitania (a actual Idanha-a-Velha).

Esta cidade, criação de Augusto, já existia em 16 a. C. cit., p. 35) tendo sido um simples oppidum governado por quatro mais tarde, na época de Vespasiano, foi elevada a municipium.

Constitui, sem dúvida, o principal aglomerado urbano dentro da área objecto de estudo deste trabalho. O limite sul do território desta civitas era o Tejo, os limites nascente a poente eram definidos respectivamente pelo rio Erges e pelas serras da Gardunha e Muradal. O limite norte é difícil de traçar, se bem que seja definido pelos dois termini augustales (padrões) encontrados em Salvador (Penamacor) e em Peroviseu (Fundão). Verifica-se, assim, que sete das oito barragens estudadas no distrito de Castelo Branco se localizariam na civitas dos Igaeditani.

$\mathrm{Na}$ Fig. 33 apresenta-se a localização das estações romanas descritas e cartografadas por J. ALARCãO $1988 \mathrm{~b}$ na região de implantação das barragens estudadas, bem como a rede viària identificada até finais dos anos 80 (idem, 1988a). 
Verifica-se que cinco das barragens se situam em áreas fortemente romanizadas, em que, além da agricultura, se praticou a actividade mineira. Uma das razões que pesam para a selecção do local de implantação da cidade de Egitânia poderá mesmo ter sido a riqueza de toda a região em ouro de aluviões (idem, 1988a).

No que respeita a rede viària romana desta zona, a via de maior importância corresponde, sem dúvida, à que, vinda de Emerita Augusta, passava por Egitânia, seguindo daqui para Viseu.

Neste último troço, essa via, após atravessar a ribeira de Meimoa, afluente do Zêzere passaria pelo vicus Talabara, que corresponde à actual povoação de Capinha (idem, 1988a). A barragem de Egitânia situa-se nas proximidades imediatas desta via, enquanto que as barragens do Rochoso, da Lajinha e da Orca distam dela, respectivamente cerca de 5,8 e $7 \mathrm{~km}$.

$\mathrm{Na}$ Fig. 33 podem observar-se vários cruzamentos desta via principal com outras. Um desses cruzamentos corresponde a uma estrada que parte na direcção de Penamacor, passando de seguida no vicus Venia (Cabeço do Lameirão), após o atravessamento da ribeira de Meimoa, seguindo para norte. De Egitânia partiam outras duas vias: uma para Lancia Oppidana , que Jorge de Alarcão (informação pessoal de 1993) julga situar-se em Portugal actualizando opinião anterior (idem, 1988a), e outra com destino a Castelo Branco, verificando-se passar nas proximidades imediatas da barragem de N. Senhora de Mércoles. Naquela cidade dar-se-ia o cruzamento desta via com outra vinda do norte, que passaria pela capital dos Tapori, antes do atravessamento do Zêzere, por Ocellum, entre este rio e a ribeira de Meimoa, e por outros vici ou castella. Descia para sul, inflectindo, antes do Ródão, para poente, com destino a Aritium Vetus, já na margem esquerda do Tejo. A barragem da Lameira dista menos de $4 \mathrm{~km}$ desta via.

A maioria das estações romanas representadas na Fig. 33 corresponde a diversos tipos de habitat, principalmente a villae, vici e castella.

\section{2 - Actividade agrícola}

As villae eram o equivalente às actuáis quintas, constituindo, pois, um tipo de habitat directamente relacionado com a actividade agrária e pecuária, podendo ter havido casos em que os seus proprietários se 
tivessem também dedicado a actividades de outra natureza, como a exploração mineira.

A paisagem beirã egitaniense, se bem que apresentando particularismos próprios, deve ter sido determinada no período romano pelas três componentes essenciais que caracterizam o espaço geográfico romanizado: o Ager ou área agrícola, por excelência; a Silva ou área de mata pouco antropizada e o Saltus ou área de charneca ou de mata muito intervencionada pelo Homem, com predominância da actividade pastoril, localizando-se, em geral, numa situação intermediária entre as duas primeiras.

O Ager ibérico foi essencialmente um espaço de sequeiro caracterizado pela tipologia mediterrânica: cereal, olival e vinha.

Todavia, a agricultura de regadio esteve quase sempre presente, se bem que limitada, em geral, a área muito mais restrita. Segundo LEVEAU 1987, pode depreender-se dos textos de Varrão e de Columela que as culturas hortícolas eram consideradas como uma "especialização suburbana intensiva". Do estudo de geografia rural antiga feito por este autor na região da antiga cidade romana de Cesareia de Mauritânia pode verificar-se repartirem-se as estruturas hidráulicas reconhecidas (tanques, barragens, captações, etc.) ao longo de uma cintura em torno da cidade.

Se esta paisagem hortícola era comum nos arrabaldes dos centros urbanos, também o deve ter sido nas áreas adjacentes das villae. Neste caso os produtos desta agricultura de irrigação reverteriam para o autoabastecimento das villae e, no caso de estas se encontrarem na periferia de centros urbanos, para esses centros (NAVARRO 1989).

Pouco se sabe quanto à natureza das culturas de regadio. Vários autores clássicos (Plínio, Columela e Justino) referem-se à irrigação da vinha na Península Ibérica (op. cit.), se bem que esta cultura predominasse na situação de sequeiro. Árvores de fruto foram também, certamente, irrigadas. Plínio refere-se à cultura de alcachofras nos arredores de Corduba e de alface nos arredores de Gades (op. cit.). Descrição mais pormenorizada das culturas de regadio é dada por Santo Isidoro de Sevilha (560-636 d.C.), nas suas Etimologiae. Nesta obra, cita-se que nas hortas do Sul peninsular se cultivavam muitas plantas, como a couve (caulis), o nabo (napus), o rabanete (rabanus), o aipo (apium), a alface (lactuca), o alho (alium), o feijão verde (phaselus), o 
pepino (cucumis), a abóbora (cucurbita), o espargo (asparagus), etc. (VENTURA 1989). Também se refere um tipo de uvas pela designação de "46uvae suburbanae" (porque se cultivavam nos subúrbios das cidades) que eram muito possivelmente produto de cultura irrigada (op. cit.).

Os sistemas de irrigação romanos na sua maioria devem ter-se alimentado a partir de nascentes e de captações em poços e rios, mediante a utilização de sistemas elevatórios. Santo Isidoro cita três tipos distintos: a ciconia (a tradicional cegonha), o girgillus (cilindro com corda enrolada ou sarilho) e a rota ou austra (tipo de nora) (VENTURA 1989). Outras fontes de alimentação hídrica utilizadas pelos Romanos foram os açudes e as barragens de retenção, obras construídas em cursos de água, a partir das quais partiam canais de adução às áreas de irrigação (QUINTELA et al 1986, 1991).

\section{3 - Actividade mineira}

"É notável que por todo o aro de Monsanto apareçam com frequência denários da idade consular. O povo já os conhece perfeitamente ..." (VASCONCELOS 1917, p.305).

Tal riqueza deverá explicar-se, ao menos em parte, pela ocorrência de explorações mineiras. HIPÓliTo (1960/61) noticia o achado no concelho de Penamacor de dois tesouros monetários, ambos constituídos por denários republicanos e de Augusto, um no Carregai, freguesia de Águas, e outro na Barroca do Antero, perto de Aldeia do Bispo. Existirá, pois, com grande probabilidade, uma relação directa entre a exploração mineira ali testemunhada e este tesouro.

HiPÓLITO 1960/61 refere, também, vários achados de tesouros monetários no concelho de Idanha-a-Nova:

- em Idanha-a-Nova, cerca de $10 \mathrm{~kg}$ de moedas de bronze do Baixo Império;

- nas proximidades de Idanha-a-Velha, denários republicanos;

- no sítio de Atalaia, herdade do Poço do Salvado, a $5 \mathrm{~km}$ de Monsanto, denários republicanos, dentro de um vaso de prata,

Noticia ainda aquele autor o achado no concelho de Castelo Branco, na freguesia de Monforte da Beira, "juntamente com xorcas de prata, de denários da República romana” (op. cit., p.71). 
No concelho de Proença-a-Nova, no sítio designado por Castelo do Chão do Trigo, freguesia de Peral, foram achados, cerca de 1712, mais de 300 denários imperiais, como HIPÓLITO 1960/61 indica ter sido registado nas Memorias Parochiaes de 1758.

Outros locais em que foram achados tesouros monetários romanos, com interesse para este estudo, são os seguintes (HIPÓLITO 1960/61):

- em Alcaide (Fundão), pequeno tesouro de denários com legenda ibérica;

- em Sendinho da Senhora (Oleiros), conjunto constituído por mais de 100 denários, dos quais os 79 examinados eram republicanos.

No concelho de Penamacor, perto das "cortas da Presa", foram encontrados numa vasilha de barro, 60 denários, os quais, tendo sido estudados por Elias Garcia, revelaram ser 36 consulares, 4 de Marco António e 17 de Augusto (ALBERTOS e BENTO 1977, p. 1203). A cronologia deste tesouro é analoga às duas anteriores.

A riqueza da região na época romana encontra-se, ainda, bem expressa pelo achado de objectos preciosos, como os que constituem o conhecido tesouro funerário da Lameira Larga, limite de Aldeia do Bispo, concelho de Penamacor, do século I d.C. Sobressai a conhecida pátera de prata representando a cena mitológica da expedição de Perseu (ROCHA 1909). Pela tipologia de uma lucerna que acompanhava o conjunto, VASCONCELOS (1920, p. 107) situa-a entre os séculos I a. C. e I d. C.

Por se relacionar com a villa de S. Lourenço, a jusante da barragem do Rochoso, menciona-se, também, a existência de uma bulia de ouro, encontrada em uma sepultura do século I d. C., pertencente por certo à necrópole da dita villa, bem como moedas, anéis e brincos de ouro, de outras sepulturas (ALMEIDA e FERREIRA 1956, 1968).

No Museu de Francisco Tavares de Proença Júnior, em Castelo Branco, conserva-se um conjunto de joias de prata - xorcas e fíbulas encontradas num esconderijo ao pé das muralhas de Monsanto da Beira (VASCONCELOS, 1920, p. 102). Estas peças estavam associadas a denários republicanos dos séculos III - I a. C. O mesmo autor cita o aparecimento de outros objectos valiosos no aro de Monsanto, como 
um conjunto de 73 denários republicanos e de um vaso de prata que os continha, na herdade do Poço do Salvado, a cerca de $5 \mathrm{~km}$ de Monsanto.

A ara encontrada na zona de Monsanto e dedicada a Júpiter, em acção de graças pela recolha de 120 libras (cerca de $40 \mathrm{~kg}$ ) de ouro pelo consagrante, que recebeu a cidadania provavelmente de Cláudio, bem demonstra o que ficou dito. ALARCÃO, na síntese que apresenta sobre a mineração romana em Portugal, refere que, como aquele, "muitos outros proprietários haveria, na Beira Baixa, enriquecidos por explorações privadas deste metal" (op. cit. 1988, p. 127).

Pode verificar-se, pelos elementos expostos, que a larga maioria dos achados remonta ao século I a. C. ou ao século seguinte; desta forma, associando-os com as explorações mineiras, estas terão, também, finalizado ou reduzido a sua importância no decurso do século II d. C. O luxo destes objectos prova a riqueza dos habitantes - da tribo Igaeditani - certamente enriquecidos pelas explorações mineiras da região enquanto elas existiram.

Com efeito, é conhecida de há muito a riqueza aurífera do Tejo e dos seus afluentes, na região em estudo. Plínio o Velho no capítulo XXII do quarto livro da sua História Natural refere que "as areias deste rio (do Tejo) são ricas e abundantes de ouro..." (in LANDEIRO 1938, p.75). Segundo este autor, no Dicionário Geográfico do P.e Luís Cardoso há duas referências à exploração de ouro no Tejo, uma relativa à Amieira, outra a Malpica. A procura de palhetas de ouro prolongou-se até época recente, apenas a tendo interrompido a subida das águas em resultado da construção da barragem de Cedilho (LANDEIRO 1938, p. 76).

As afirmações de Plínio encontram-se, pois, não apenas documentadas em tempos recentes, mas também por vestígios coevos.

$\mathrm{Na}$ área que interessa a este estudo, SCHWARZ 1936 (p. 36) refere ter encontrado "vestígios de explorações auríferas romanas... nos aluviões dos rios Baságueda, Erges, Aravil e Ponsul e dos diversos afluentes do Erges e do Tejo, nos sítios de Monfortinho, Salvaterra do Extremo, Rosmaninhal, etc." 
O mesmo autor refere ainda (op. cit., p. 36):

"Estes vestígios de trabalhos romanos podem-se dividir em duas categorias:

Io - Trabalhos a céu aberto; e

2o - Trabalhos subterrâneos.

Aos primeiros pertencem as grandes escavações existentes no sítio da Carreira do Tiro, perto de Penamacor, e os montes de pedras aluviais alinhados nas beiras do Erges, no sítio das Caldas de Monfortinho, numa extensão de alguns quilómetros.

Aos segundos pertencem as antigas galerias subterrâneas que existem na região de Rosmaninhal, nos sítios do Cabeço do Mouro, Couto, Minas, Santa Marinha, Algarves, Fonte Santa, Cubeira, etc.”

Segundo Schwarz, os muitos pesquisadores de ouro que reconheceram essas galerias não encontraram "uma só fractura filoniana de quartzo aurífero". Assim, as galerias serviam de "canais para onde as águas, arrastando as terras auríferas, eram encaminhadas por meio de poços de comunicação", sendo o ouro depositado nas galerias, o que assegurava protecção contra o roubo durante a exploração. Os poços de comunicação, segundo aquele autor, eram na época reconhecíveis com nitidez.

Cita LOBATO 1982 (p. 171): "Na Bazaguedinha ainda eu assisti, muitas vezes, a este género de procura de ouro feito por homens das Aranhas e do Salvador." CARVALHO e FERREIRA 1954 referem a importância aurífera dos aluviões do Erges, onde, na época, se encontravam registadas diversas concessões na freguesia de Salvaterra do Extremo.

Ainda em 1825, o Barão de Eschwege referia num relatório "a actividade dos povos da região que apanhavam o ouro da terra, vendendo-o aos ourives das vilas próximas" (in CARVALHO e FERREIRA 1954, p. 28). Na área em estudo, os vestígios mais espectaculares observam-se na região de Penamacor, próximo da Carreira de Tiro. Trata-se das "cortas da Presa", segundo a designação de ALBERTOS e BENTO 1977. Dali se retiraram, como no Rosmaninhal, muitos milhões de $\mathrm{m}^{3}$ de sedimentos; a técnica utilizada para estas explorações poderia ser a que descreve Plínio. Allan 1965, p. 155, citando-o, refere que os Romanos armazenavam a água em tanques situados a cotas elevadas, munidos de comportas, que abriam repentinamente; a água, em jorros, fazia o desmonte dos depósitos 
(ruina montiuni) $\mid$ o transporte ulterior destes promovia o depósito das partículas auríferas em caleiras, pelo efeito das diferenças de densidade, sendo os blocos ou seixos de maiores dimensões retirados manualmente. Só explorando grandes quantidades de sedimentos se poderia atingir rentabilidade, visto o teor de ouro ser muito baixo.

BENTO 1975 refere que à data se podiam observar, próximo da Carreira de Tiro de Penamacor, no local conhecido pela "Presa", grandes represas e canais para condução de água destinadas às explorações mineiras" (p. 952) o que, contudo, não se confirmou no reconhecimento de campo efectuado para este estudo. No entanto, a observação da fotografia aérea revelou a existência de um possível reservatório a cota susceptível de permitir a utilização para desmonte hidráulico. Desse reservatório partiriam dois canais de adução de água para a costa principal, segundo a fotointerpretação realizada.

Do que ficou dito, pode concluir-se que toda a região em causa contém abundantes vestígios de mineração romana, explorando-se, essencialmente, o ouro aluvionar e dos depósitos terciários, os quais constituem, por vezes, extensas coberturas detríticas sobre o substrato paleozoico. Existem abundantes provas arqueológicas da riqueza da região através do achado de tesouros monetários e de objectos preciosos em sepulturas. O testemunho mais expressivo é a inscrição de uma ara de Monsanto, que um cidadão romano dedica a Júpiter em acção de graças por ter recolhido $40 \mathrm{~kg}$ de ouro. As explorações iniciaram-se no século I a. C., ou ainda antes, e decaíram no século II d. C., como se deduz pela cronologia dos achados. O declínio das explorações auríferas romanas é, com efeito, assinalado a partir do século II d. C. (Allan 1965, p. 158).

\section{7 - CRONOLOGIA E FINALIDADE DAS BARRAGENS ESTUDADAS}

\section{1 - Cronologia das barragens}

Com excepção da Presa de Penamacor (de que não há vestígios e de que só se dispõe de informação bibliográfica) e da barragem de Alferrarede, as restantes oito barragens estudadas são consideradas do período romano. Destas, duas são de alvenaria (Nossa Senhora de 
Mércoles e Souto do Penedo) e seis de terra (Lajinha, Orca, Rochoso, Egitânia, Monforte e Lameira).

A atribuição da origem romana às barragens de Nossa Senhora de Mércoles, Lajinha, Orca, Rochoso e Egitânia justifica-se, em primeiro lugar, pelos muito abundantes vestígios romanos nas suas imediações. Para as restantes barragens aquela atribuição baseia-se na analogia tipológica: barragem de Souto do Penedo comparável à de Nossa Senhora de Mércoles (e outras barragens estudadas a sul do Tejo) e barragens de Monforte e Lameira comparáveis às de Lajinha, Orca, Rochoso e Egitânia).

Existe, porém, uma informação adicional sobre a barragem da Orea que é muito relevante para apoiar a atribuição da sua origem romana. Trata-se de uma referência, datada de 1505, constante dum tombo da Ordem de Cristo, admitindo-se pelo texto da mesma que nessa data a barragem já estivesse desactivada.

Em face das características da ocupação da zona no período entre o termo da ocupação romana e a data da referência mencionada, não se apresenta verosímil que a barragem da Orca (e analogamente as restantes) tivesse sido construída nesse período.

Com efeito, "só muito tardíamente a Beira Baixa recebeu colonização intensiva. Nos séculos medievos, a Ordem do Templo e a sua sucessora de Cristo, grandes proprietárias das regiões beirãs, parece terem-se preocupado apenas com a defesa militar e descurado as práticas da terra" (segundo refere Orlando Ribeiro, citado por MARQues, 1978, p. 70). Deste modo, dificilmente se justifica a atribuição da barragem da Orca à Idade Média, quer ela se destinasse à agricultura, quer à exploração mineira.

Por outro lado, para o período entre a ocupação romana e o final da Idade Média (próximo da data da referência da Orca, 1505) o número de barragens na Península destinadas a criar albufeiras é muito escasso (ver 5.1.1).

Considera-se, assim, confirmada a origem romana da barragem da Orca. Em virtude da analogia tipologica e dos abundantes vestígios romanos nas imediações, as barragens da Lajinha, Rochoso e Egitânia terão a mesma origem.

As barragens de Monforte e da Lameira, com características análogas às das atrás mencionadas, mas sem vestígios romanos abundantes nas proximidades imediatas, serão, também, provavelmente, do período romano. 
Dentro desse período, é de admitir que as barragens estudadas tenham sido construídas entre os finais do século II a. C. e os inícios do século II d. C., intervalo de tempo em que a mineração atingiu a sua maior importância, partindo do princípio que estas estruturas estivessem relacionadas com tal actividade económica.

\section{2 - Finalidades das barragens}

A finalidade de grande parte das barragens terá sido provavelmente o apoio à actividade mineira. Apenas no caso da barragem do Rochoso se encontraram com o abastecimento doméstico de uma importante villa e evetualmente com o regadio da zona adjacente.

A actividade mineira está bem documentada região, como foi ampiamente exposto em 6.3.

Por outro lado, pôde verificar-se, para cada barragem estudada, com excepção da do Rochoso pelo menos, uma das seguintes situações:

- inexistência de villae a jusante;

- desconhecimento de vestígios de canais de adução entre as barragens e os habitats romanos a jusante, quando existem;

- recurso verificado a nascentes ou poços para a alimentação das villae nas proximidades das barragens (ou possibilidade desse recurso);

- inexistência a jusante de solos propícios à rega.

A actividade mineira teria consistido essencialmente na extracção de ouro dos aluviões ou de depósitos detríticos mais antigos que se podem observar a jusante de qualquer das barragens estudadas $\mathrm{e}$ relativamente próximo delas.

Ainda que a exploração dos recursos auríferos, no mundo romano, fosse geralmente reivindicada pelo Estado, não seria talvez esse o caso da exploração aluvionar do território dos Igaeditari (Alarcão, informação pessoal de 1993).

Sendo assim, a construção das barragens terá sido obra de ricos proprietário da região cujas villae se devem sistematicamente procurar, quer a jusante, quer a montante. A sua ausência poderá levar a concluir por uma exploração municipal ou estatal. Neste caso, porém deveriam encontrar-se os povados dos exploradores. A hipótese que parece de excluir é a de uma população modesta, dispersa por casais, conjugando esforços para a construção de barragens de interesse colectivo (idem). 
Domergue 1986 afirma que, dum modo geral, todos os depósitos detríticos (aluviões, terraços quaternários e depósitos terciários) de Portugal a norte do Tejo (Fig. 34), qualquer que fosse a sua importância, teriam sido explorados pelos Romanos. Tal afirmação é, portanto, aplicável à região em estudo.

Domergue 1986 refere ainda o teor de 20 a $40 \mathrm{mg} / \mathrm{m}$ para os sedimentos mais pobres (depósitos terciários) e algumas décimas de $\mathrm{g} / \mathrm{m}^{1 * 3}$ para os mais ricos (parte superficial dos terraços quaternários). Tais explorações a grande escala exigiram, por outro lado, consideráveis volumes de água, que de facto se encontra disponível no local. Aquele autor avaliou que o tratamento de $1 \mathrm{~m}^{3}$ de sedimentos requeria 10 a $12 \mathrm{~m}^{3}$ de água, tanto mais que a água era também indispensável à evacuação dos estéreis.

Conhecem-se no mundo romano vários casos de utilização para mineração de água armazenada em albufeiras.

Em território português são de há muito conhecidas três barragens em Jales (Vila Pouca de Aguiar) e duas em Três Minas (idem) que forneciam água para a exploração aurífera.

Também em Espanha se conhecem cinco barragens em Melque (S. Martin de Montalbán) cuja água era provavelmente utilizada em minas de galena argentífera (CABALLERO ZOREDA e SANCHEZ RAMOS 1982).

Outras barragens utilizadas pelos Romanos para apoio à mineração aurífera localizam-se em Rosia Montana (Roménia), como referido em 5.1 .

\section{8 - CONCLUSÕES}

Estudam-se no presente trabalho os vestígios de seis barragens de terra e duas de alvenaria do distrito de Castelo Branco e uma de alvenaria (barragem de Alferrarede) do distrito de Santarém.

São possíveis as seguintes conclusões:

1 - As barragens de terra assumem características relevantes nalguns casos, atingindo os seguintes valores máximos:

- altura de 11 m (barragem da Egitânia);

- desenvolvimento de $380 \mathrm{~m}$ (barragem da Lameira);

- volume de aterro de $16000 \mathrm{~m}^{3}$ (barragem da Lameira);

- capacidade da albufeira de $840000 \mathrm{~m}^{3}$ (barragem da Lameira). 
Não se observaram vestígios de descarregadores de superfície e de descargas de fundo.

2 - As barragens de terra foram atribuídas ao período romano, essencialmente, com base nos seguintes elementos:

- abundância de vestígios romanos nas áreas envolventes;

- ausência de referências a barragens de terra constituídas na Europa, durante a Idade Média, com a finalidade de criar albufeiras;

- escassa ocupação humana desta região da Beira Baixa durante a Idade Média e referência à barragem da Orca em documento de 1505 .

3 - As barragens de terra caracterizadas assumem, assim, grande importância no contexto do Mundo Romano em face da escassez de estruturas comparáveis exclusivamentede de terra.

4 - Os vestígios dos aterros evidenciam o recurso a técnicas adequadas na sua execução.

5 - A finalidade mais provável da maior parte das barragens de terra terá sido o apoio à actividade mineira (exploração de ouro, ampiamente documentada na região) que exigiria assinalável disponibilidade de água.

6 - As duas barragens de alvenaria do distrito de Castelo Branco são análogas às barragens romanas estudadas pelos autores a sul do Tejo.

7 - A barragem de Alferrarede é muito mais moderna do que as restantes; as suas características aproximam-na da barragem da Represa (Gavião) e de barragens construídas em Espanha na época filipina. Assinale-se, porém, que se reconheceram, junto dos encontros, muros de opus signinum que pressupõem a anterior existência de uma obra romana. ${ }^{8}$

8 - A construção de barragens na área em estudo com a finalidade de criar albufeiras era justificada pela irregularidade dos cursos de água determinada pela escassa precipitação anual média, em geral, inferior a $800 \mathrm{~mm}$. 


\section{AGRADECIMENTOS}

À Direcção-Geral dos Recursos Naturais e, em particular, aos seus Directores-Gerais Francisco Nunes Correia, António Miguel Cavaco e Rui Roda, agradecemos o apoio dispensado e o interesse manifestado por este trabalho.

Ao Eng $^{\circ}$ Dias Agudo e Eng ${ }^{\circ}$ Moacyr de Melo daquela Direç̧ão-Geral agradecemos as suas intervenções respectivamente, para a desmatação da área envolvente da barragem de Alferrarede e para a obtenção dos elementos topográficos de barragens e albufeiras, utilizados neste trabalho.

Agradecemos ainda:

- ao Dr. J. Candeias da Silva, as informações relativas às barragens da Orca e de Alferrarede;

- a João Caninas e a Francisco Henriques, as informações relativas às barragens de Monforte e Lameira;

- ao Dr. António Salvado, a Pedro Salvado e a Joaquim Baptista dos Santos, as informações relativas às barragens de Rochoso e Nossa Senhora de Mércoles;

- ao Padre José Maria Félix, as informações relativas à barragem de Souto do Penedo e a outras estruturas de concelho de Vila de Rei;

- ao Eng ${ }^{\circ}$ Miguel Paes do Amaral, informação e documentação familiar sobre a barragem de Alferrarede;

- a Aristides Galhardo Mota, encarregado do Museu Municipal de Penamacor, informações sobre a "Presa" de Penamacor.

- ao Eng ${ }^{\circ}$ Manuel de Almeida da Garrett, informações complementares sobre a barragem de Monforte.

Um agradecimento muito especial é devido ao Prof. Doutor Jorge de Alarcão pela leitura crítica do original, de que resultaram úteis sugestões, bem como pelo amável convite para este volumoso trabalho, que gostosamente aceitámos.

O processamento do texto esteve a cargo de Cristina Nunes e a preparação gráfica de Bernardo Ferreira e de José Machado, a quem agradecemos a colaboração. 


\section{BIBLIOGRAFIA}

Alarcão, J. de 1988 a - Roman Portugal. 2 voi. Aris \& Philips. Warminster.

AlarcãO, J. de 1988 b - O Domínio Romano em Portugal. Pub. Europa-América. Lisboa.

Albertos, M.L. e Bento, M. Pires 1977 - Testemunhos da ocupação romana na região de Meimoa (Beira-Baixa). Actas XIV Congresso Nacional de Arqueologia (Vitoria, 1975), p. 1197-1208.

Allan, J.C. 1965 - A mineração em Portugal na Antiguidade. Bol. de Minas, 2(3), p. $139-175$.

Almeida, F. de 1956 - Egitânia. Revista da Faculdade de Letras de Lisboa. Lisboa.

AlmeidA, F. de e Ferreira, O. da Veiga 1956 - Antiguidades de Monsanto da Beira. Revista de Guimarães, 66(3/4), p. 407-425.

AlmeidA, F. de e FerreirA, O. da Veiga 1968 - Uma bula de ouro encontrada em Portugal. O Arqueólogo Português, S.III, 2, p. 7 1-75.

AzEvedo, P. A. 1898 - Extractos archeologicos das Memorias Parochiaes de 1758. O Arqueólogo Português, 4, p. 321-322.

Bento, M. Pires 1975 - Inscrições romanas de Meimoa. Beira Baixa. Actas XIII Congreso Nacional de Arqueologia (Zaragoza, 1975), p. 951-956.

BLAZQUEZ, J.M. 1975 - Historia social y economica de la España romana. Segunda parte. Siglos III-V. Confederation Española de Cajas de Ahorros. Madrid.

BotZAN, M.; LeIN K. e Vogel, A. 1992 - Historiche Sperrenbauten in Rumänien.

In Historiche Talsperren, 2, p. 371-379. Verlag K. Wittwer. Stuttgart.

Caballero Zoreda, L. e SAnchez Ramos, F. J. 1982 - Presas romanas y dados sobre poblamientos romano y medieval en la provincia de Toledo. Noticiario Arqueológico Hispanico, ${ }^{\circ} 14$. Madrid.

CAlvet, Y. e GeYeR, B. 1992 - Barrages Antiques de Syrie. Maison de l'Orient Méditerranéen, Lyon.

CARVAlHo, J. Silva e FERREIRA O. da Veiga 1954 - Algumas lavras auríferas romanas.

Estudos, Notas e Trabalhos do Serviço de Fomento Mineiro, 9 (1-4), p. 20-46.

DIAS, J. Lopes 1966 - Miscelania de Cartas \& Documentos Albicastrenses. E. A. Império. Lisboa.

Domergue, C. 1986 - L'eau dans les mines d'or romaines du nord-est de l'Espagne. In L'Homme et L'Eau en Méditerranée et au Proche Orient, III (L'Eau dans les Techniques). Travaux de la Maison de l'Orient, 11, p. 109-119.

Domergue, C. 1987 - Catalogue des mines et des fonderies antiques de la Péninsule Ibérique. Publications de la Casa de Velazquez, Série Archeologie Vili, Tome II. Diffusion De Boccard, Madrid.

FÉLIX, José M. 1969 - Vila de Rei e o seu concelho. 2. ${ }^{a}$ edição 1985, Câmara Municipal de Vila de Rei.

FERNÁNDEZ ORDÓÑEZ, José A. 1984 - Catálogo de noventa Presas y Azudes Españoles anteriores a 1900. Comission de Estudios Históricos de Obras Públicas y Urbanismo. Madrid.

Conimbriga, 34 (1995) 75-127 
GARBRECHT, G. 1991 a - Vier antike Talsperren in Analolien. In Historiche Talsperren, 2, p. 91-100. Verlag K. Wittwer. Stuttgart.

GARBRECHT, G. 1991b - Der Staudamm von Resafa-Sergiopolis. In Historische Talsperren, 2, p. 237-248. Verlag K. Wittwer. Stuttgart.

GARCIA, J. M. 1979 - Epigrafia e Romanização de Castelo Branco. Conimbriga, 18, p. $149-167$.

GARCIA, J. M. e LeITÃo, M. 1982 - Inscrição romana do Monte de S. Martinho Castelo Branco. Centro de Estudos Epigráficos da Beira. Castelo Branco.

HenRiQues, F. e CANINAS, J. 1990 - Notícias várias. Alto Tejo, 3, p. 4.

HenRIQues, F.; CANinAS, J. e HenRIQues, A. 1985 - Represa da Lameira. Informação Arqueológica, 5, p. 11-12.

Hipólito, M. de Castro 1960/61 - Dos tesouros de moedas romanas em Portugal. Conimbriga, 2/3: 1-166.

JPBB 1944 - Subsídios para a História Regional da Beira Baixa. Voi. 1. Ed. da Junta de Província da Beira Baixa (JPBB). Castelo Branco.

LANDEIRO, J. M. 1938 - o concelho de Penamacor, na história, na tradição e na lenda.

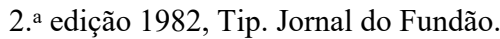

LEITÃO, M. 1983 - Tapada do Cabeço. Informação Arqueológica, 3, p. 10.

LEVEAU, P. 1987 - Aménagements hydrauliques et utilisation de l'eau dans l'Agriculture autours de Caesarea de Maurétanie (Cherchel, Algérie). In L'Homme et L'Eau en Méditerranée et au Proche Orient, IV (L'Eau dans l'Agriculture), p. 45-56. Maison de l'Orient. Lyon.

LiANDI, Z. 1991 - Talpsperren und Wehre im alten China. In Historiche Talsperren, 2, p. 110-130. Verlag K. Wittwer. Stuttgart.

LobAtO, J. Rodrigues 1982 - Esboço monográfico da parte nordeste da freguesia de Penamacor - zona da Presa e da Arrancada à luz dos anos trinta. Actas e Memorias do $I^{o}$ Coloquio de Arqueologia e de Historia do Concelho de Penamacor (Penamacor, 1979), p. 163-121.

MARQues, A. H. Oliveira 1978 - Introdução à Historia da Agricultura em Portugal. Edições Cosmos. Lisboa.

NAVARRO, P. 1989 - Obras Hidráulicas e Implantação Rural Romana en la Campiña de Cordoba. In: El Agua en Zonas Aridas: Arqueologia e Historia. Actas del I Coloquio de Historia e Medio Fisico (Almeria, 14-16 Dec. 1989), p. 361-404. Instituto de Estudios Almerienses. Almeria.

OLEIRO, D. 1952 - Abrantes, Cidade Florida. Abrantes.

ProEnÇA, F. Tavares de 1905 - Notice sur deux monuments épigraphiques. Coimbra.

ProençA, F. Tavares de 1910 - Archeologia do districto de Castelo Branco. Leiria

Quíntela, A.; CARdoso, J. e MASCARENHAS, J. 1986 - Aproveitamentos hidráulicos romanos a sul do Tejo. Contribuição para a sua inventariação e caracterização. Direcção-Geral dos Recursos e Aproveitamentos Hidráulicos. Lisboa.

Quíntela, A.; CARdoso, J. L. e Mascarenhas, J. M. 1991 - Aproveitamentos hidráulicos romanos a sul do Tejo. Contribuição para a sua inventariação e 
caracterização. Aditamento ao estudo de 1986. Relatório para a Direcção-Geral dos Recursos Naturais. Lisboa.

RochA, A. Santos 1909 - Thesouro funerario da Lameira Larga. Epoca luso-romana. O Arqueólogo Português, S. I, 14, p. 44-49.

SALVADO, Pedro 1980 - Marcas de oleiro em tégulas romanas da estação arqueológica do triângulo - Mércules, Sant'Ana, São Martinho. Estudos de Castelo Branco, Nova Série, 6 .

SCHNITTER, N. J. 1988 - The evolution of embankment dams. Water Power \& Dam Construction Handbook 1988.

SCHWARZ, S. 1936 - Arqueologia mineira. Bol de Minas. 1933, p. 35-38.

SILVA, J. Candeias 1979 - Testemunhos da presença romana na Orca (Fundão). Actas das I.as Jornadas Arqueológicas da Beira Baixa, p. 118-131.

SILVA, J. Candeias 1986 - Alferrarede Arqueológica. Jornal de Alferrarede, Nov. 1986.

SILVA, J. Candeias, 1991 - Contribuição das fontes medievas para a investigação arqueológica. Alguns exemplos recolhidos nos antigos concelhos de Castelo Novo e Alpedrinha. Comunicação às l.as Jornadas Arqueológicas da Beira Interior. Castelo Branco (em publicação).

VAsCONCElos, J. Leite de 1917 - Na Beira Baixa. O Arqueólogo Português, S. I, 22, p. 297-344.

VASCONCElos, J. Leite de 1920 - Estudos sobre a época do Ferro em Portugal. $\boldsymbol{O}$ Arqueólogo Português, 24, p. 99 -107.

VentuRA, F. 1989 - La Agricultura de Regadio durante la Antigüedad Tardia en el Sur de la Peninsula Iberica, In El Agua en Zonas Aridas: Arqueologia e Historia. Actas del 1 Coloquio de Historia y Medio Físico (Almeria, 14-16 Dici. 1989), p. 407-418, Instituto de Estudios Almerienses. Almeria.

Vita-FInZI, C. 1961- Roman dams in Tripolitania. Antiquity, vol. XXXV, p. 14-20. Londres. 


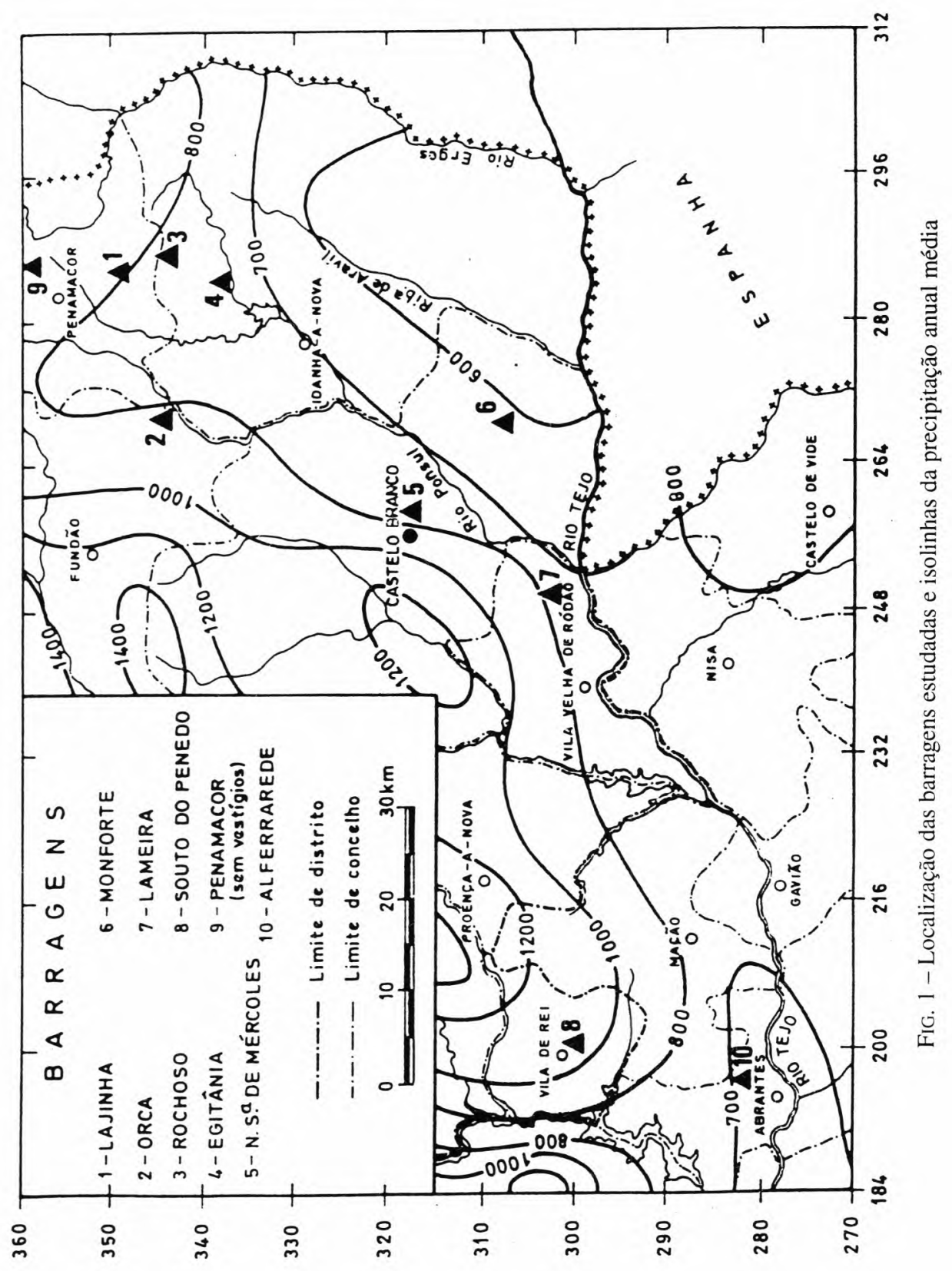




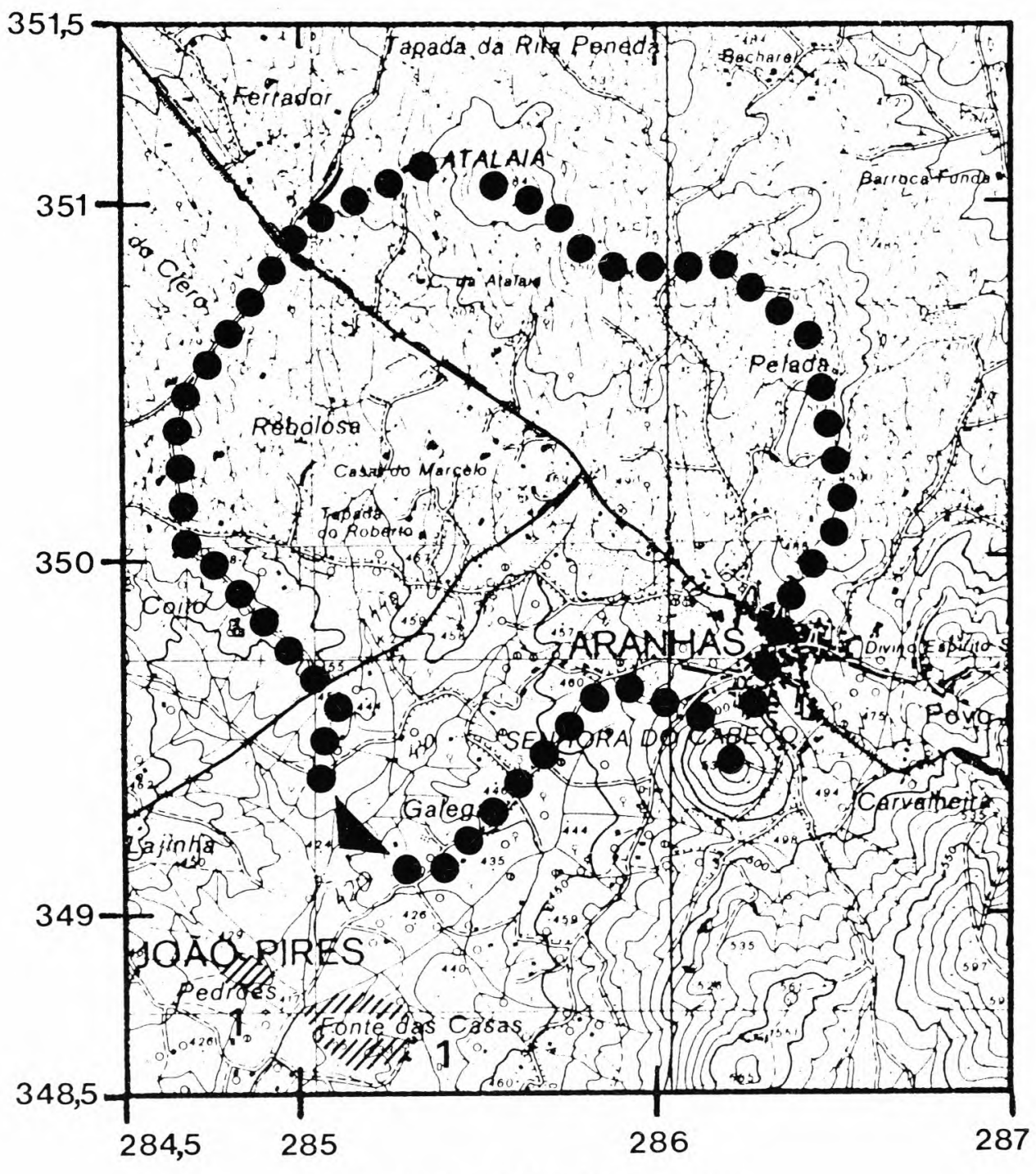

FIG. 2 - Barragem da Lajinha (Penamacor). Localização e bacia hidrográfica 


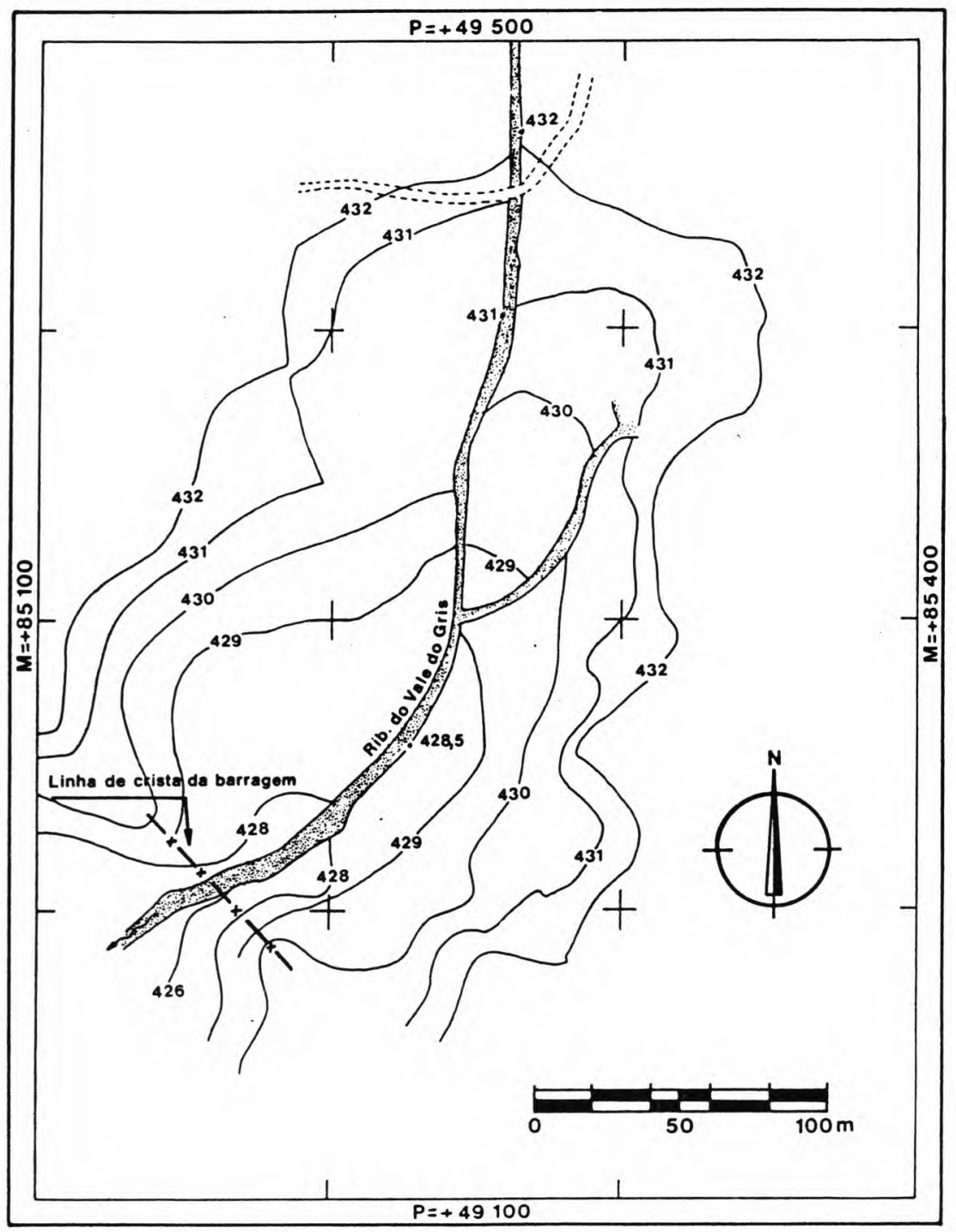

FIG. 3 - Barragem da Lajinha (Penamacor). Planta da albufeira 


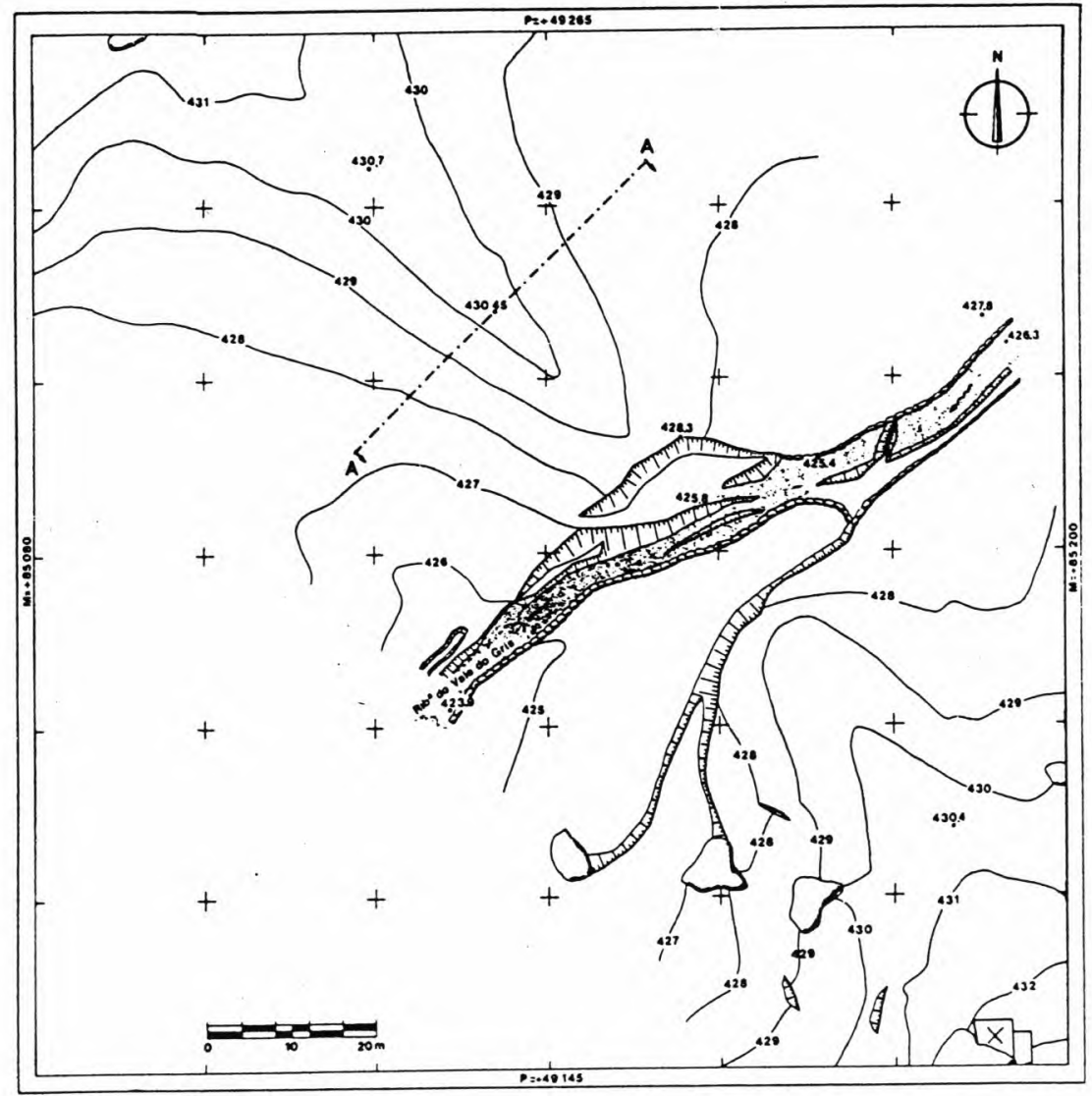

FIG. 4 - Barragem da Lajinha (Penamacor). Planta da barragem 


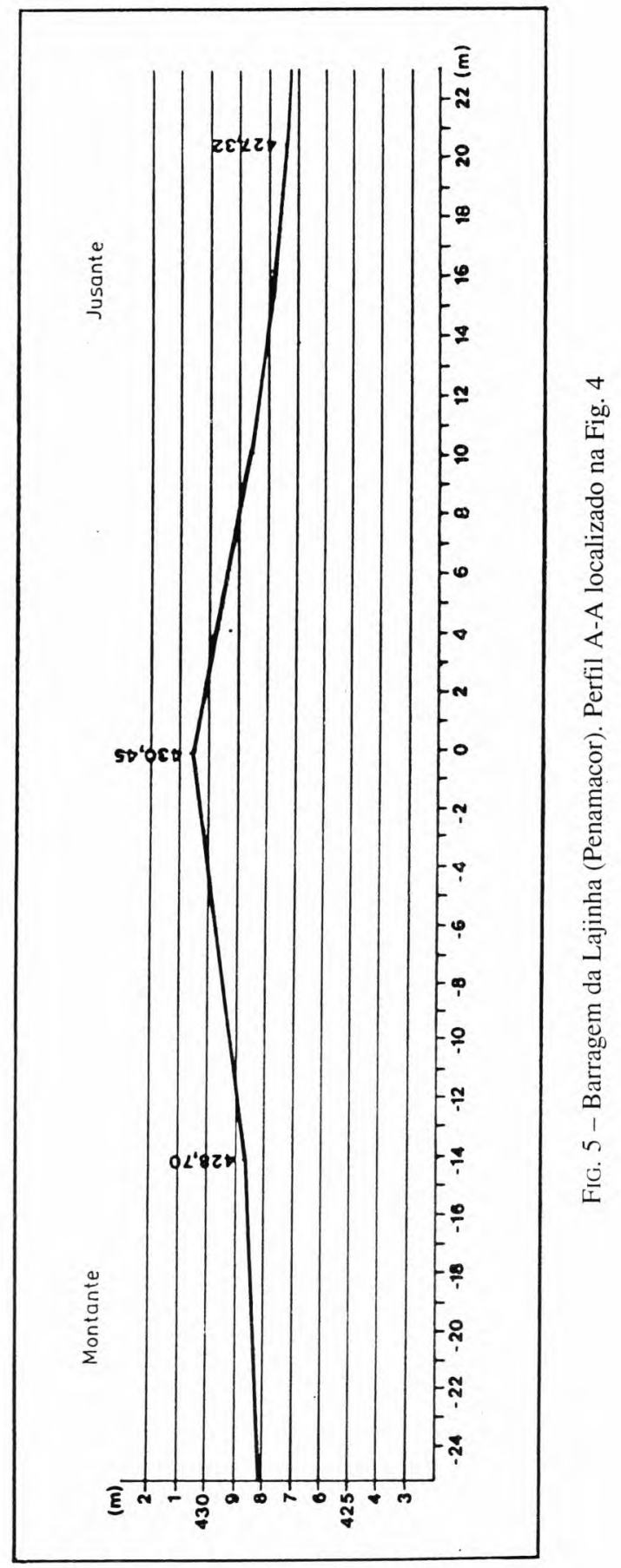




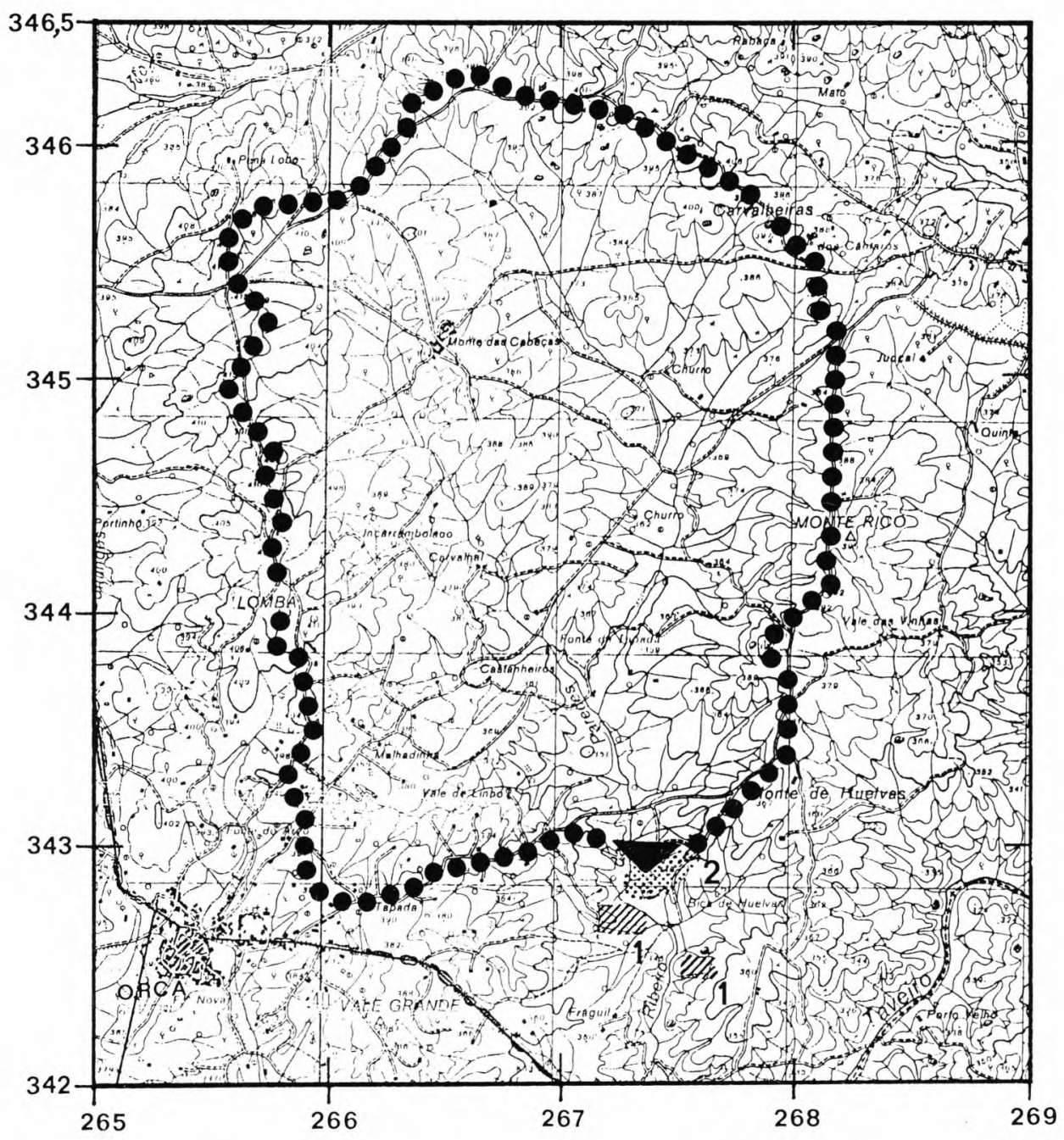

FIG. 6 - Barragem da Orca (Fundão). Localização e bacia hidrográfica 1 - Villa 2 - Vestígios de mineração 


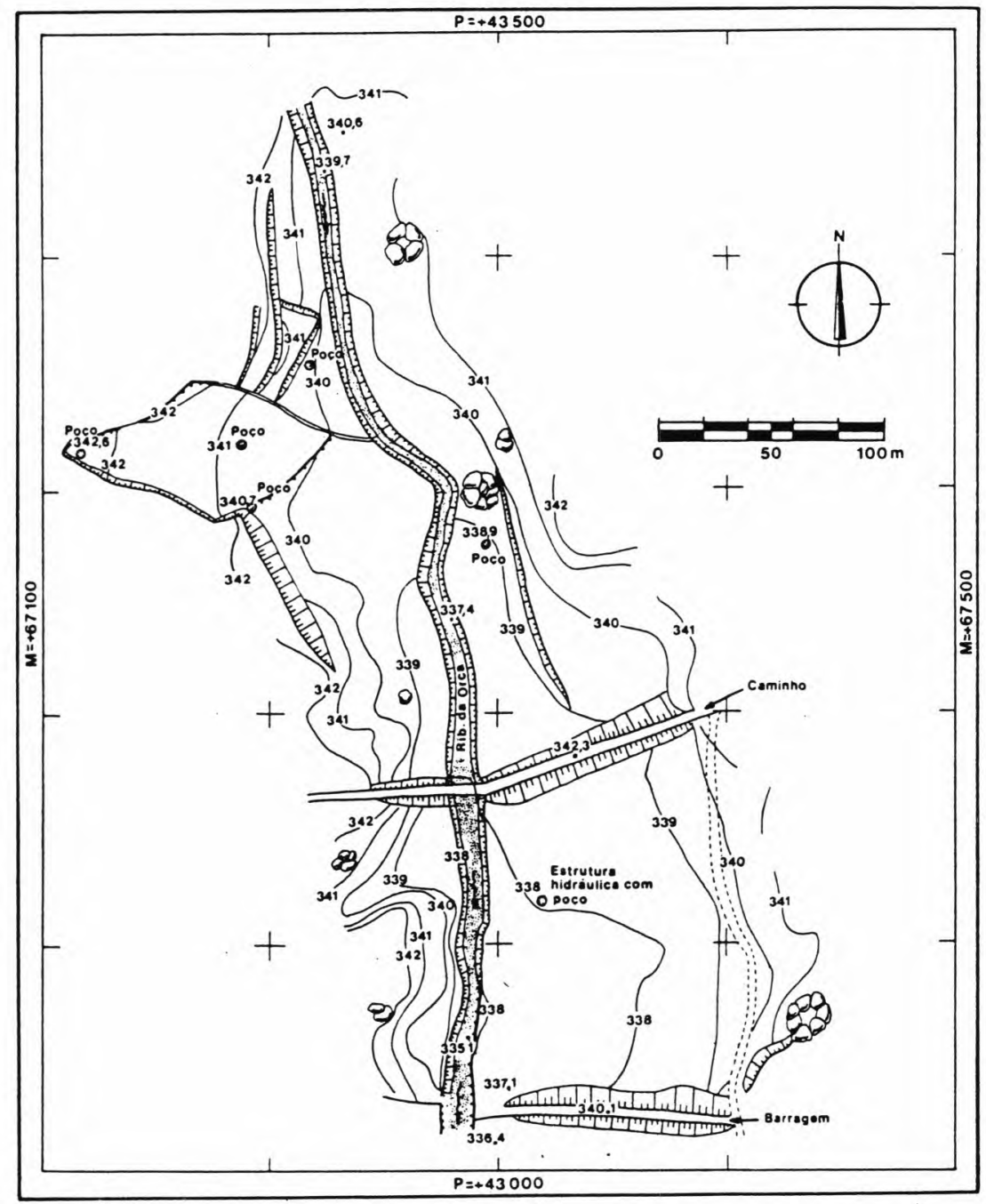

FIG. 7 - Barragem da Orca (Fundão). Planta da albufeira 


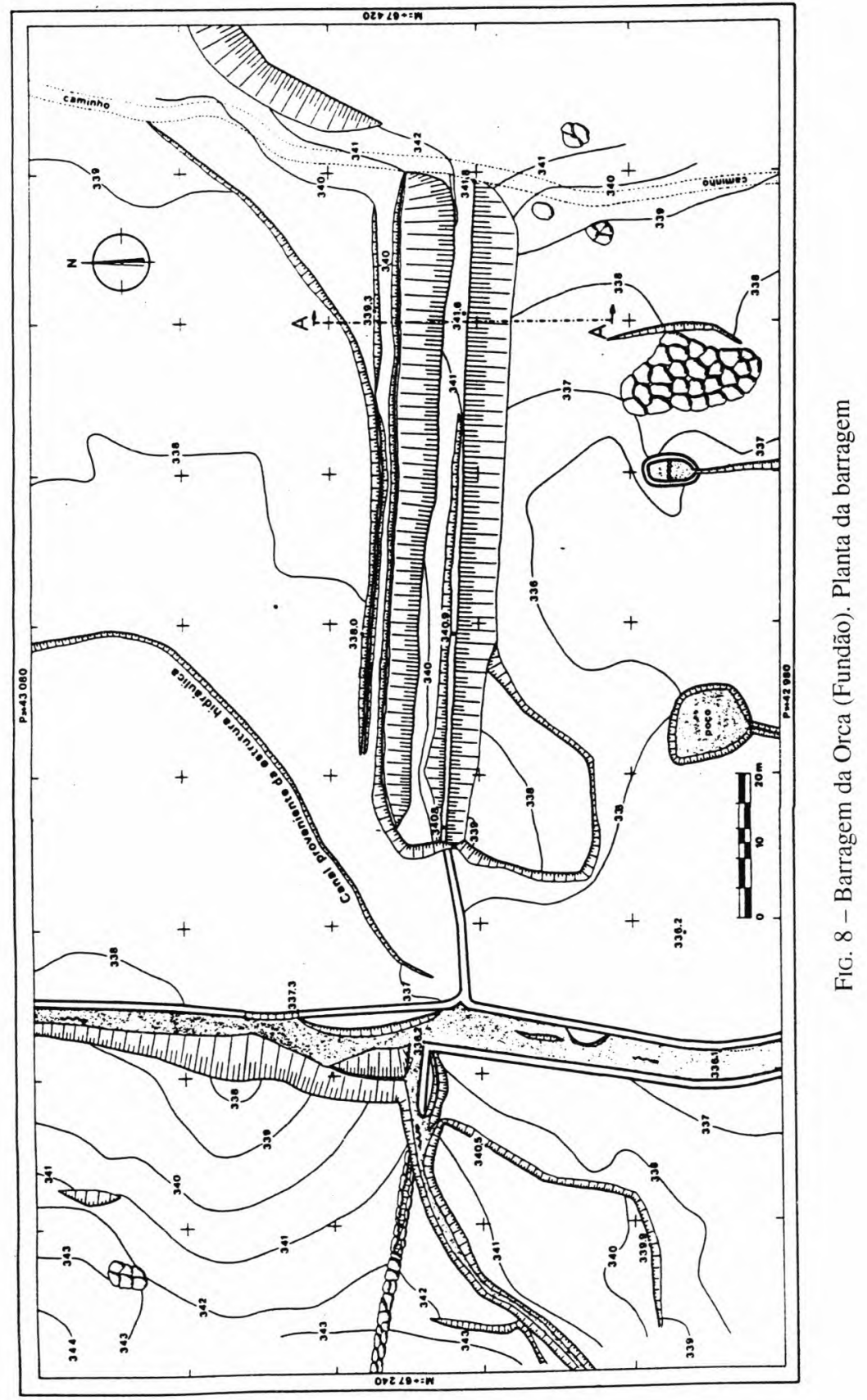




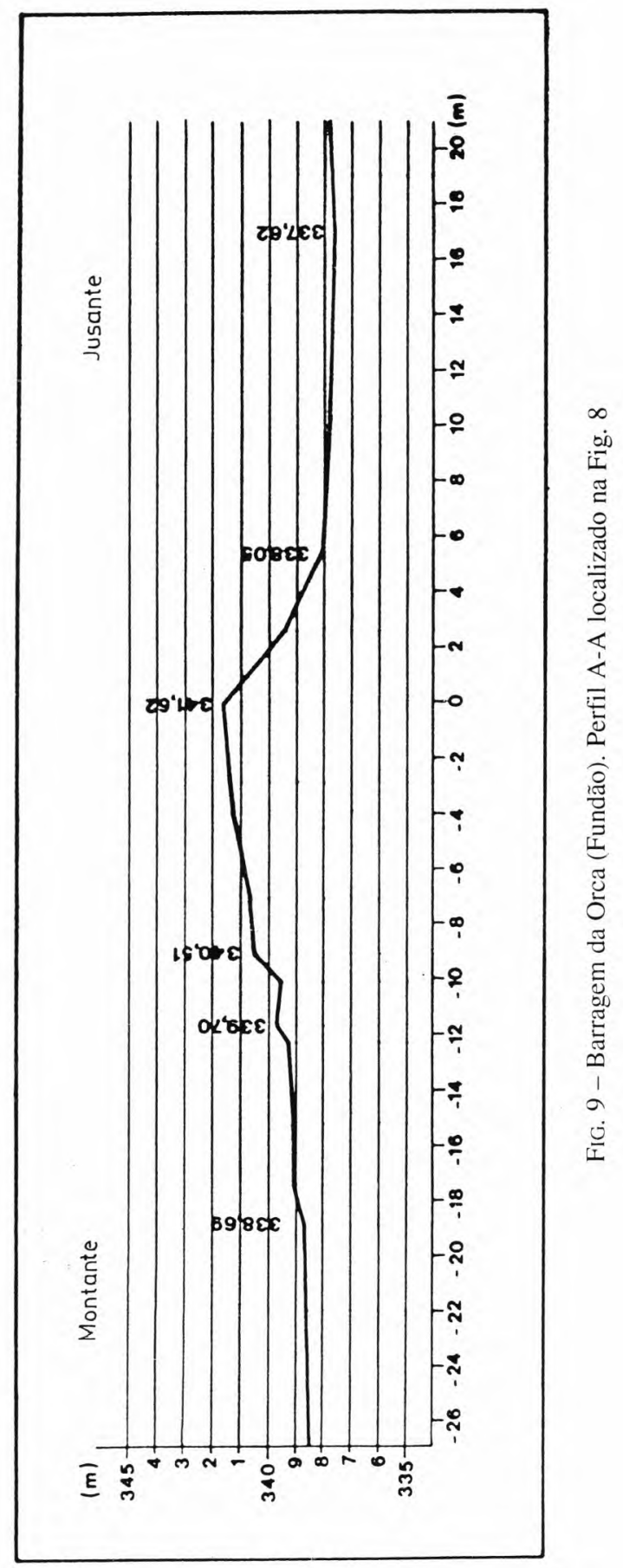




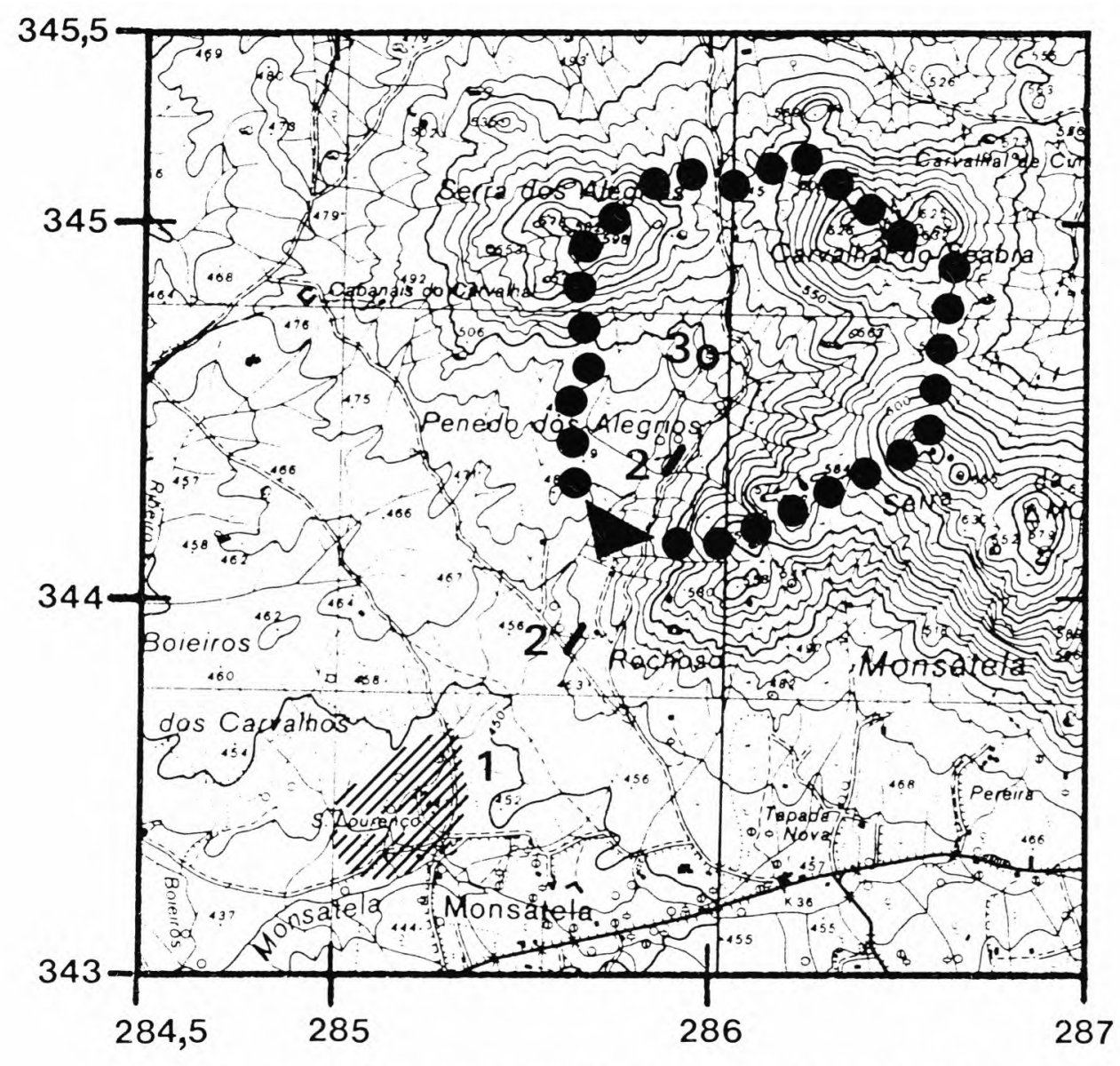

FIG. 10 - Barragem do Rochoso (Idanha-a-Nova). Localização e bacia hidrográfica 1-Villa 2 - Troço da caleira, 3 -Fonte 


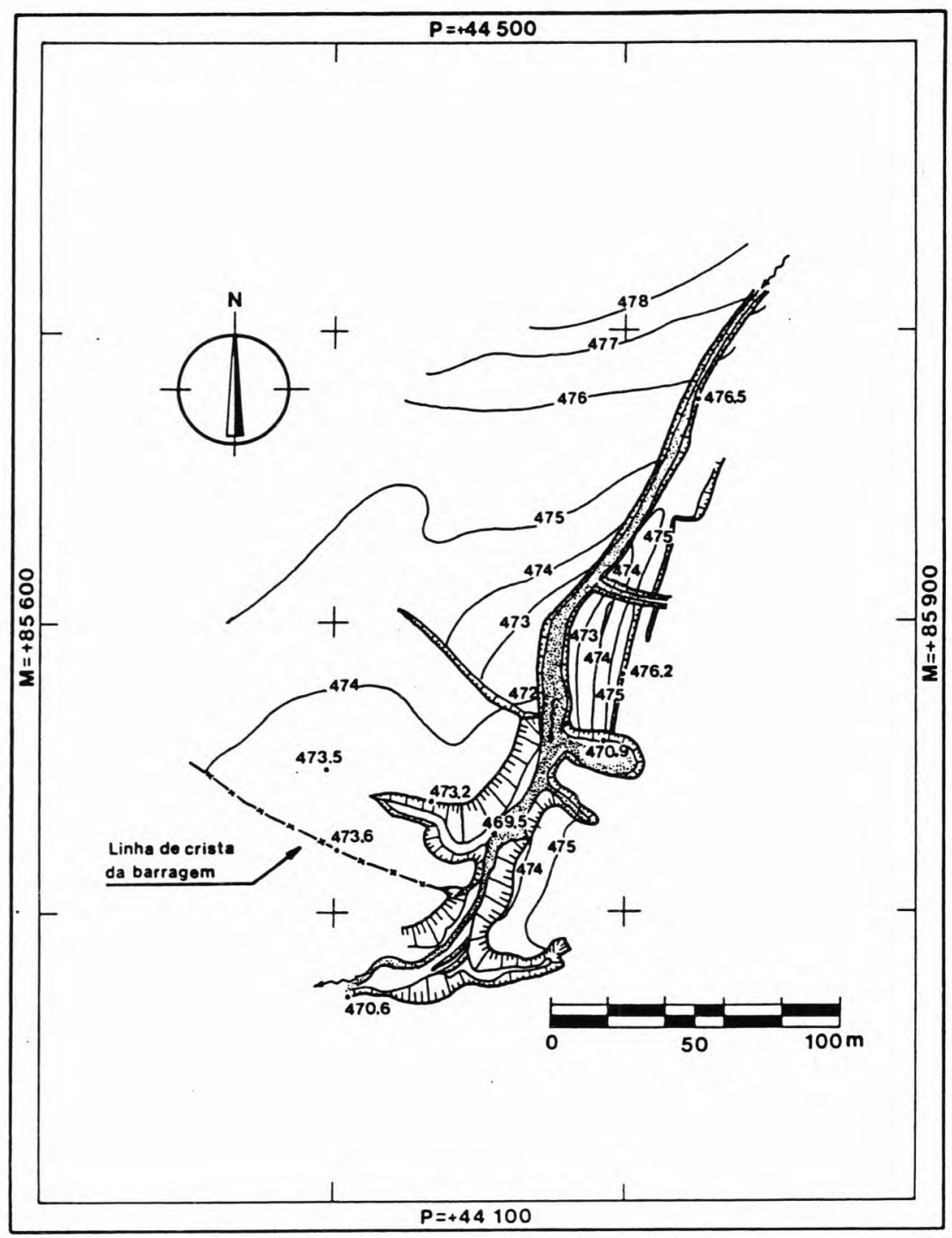

Fı́G. 11 - Barragem do Rochoso (Idanha-a-Nova). Planta da albufeira 


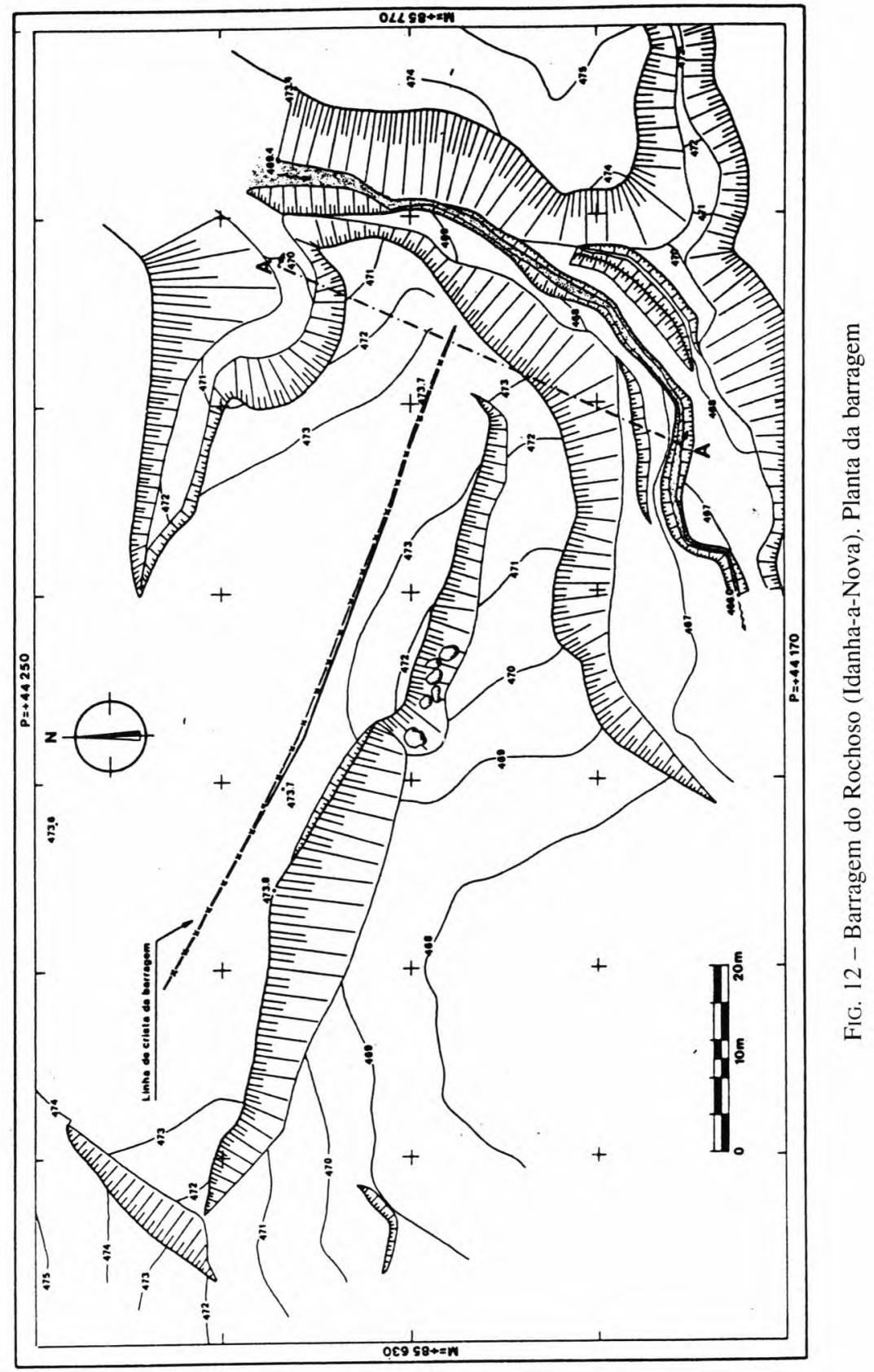




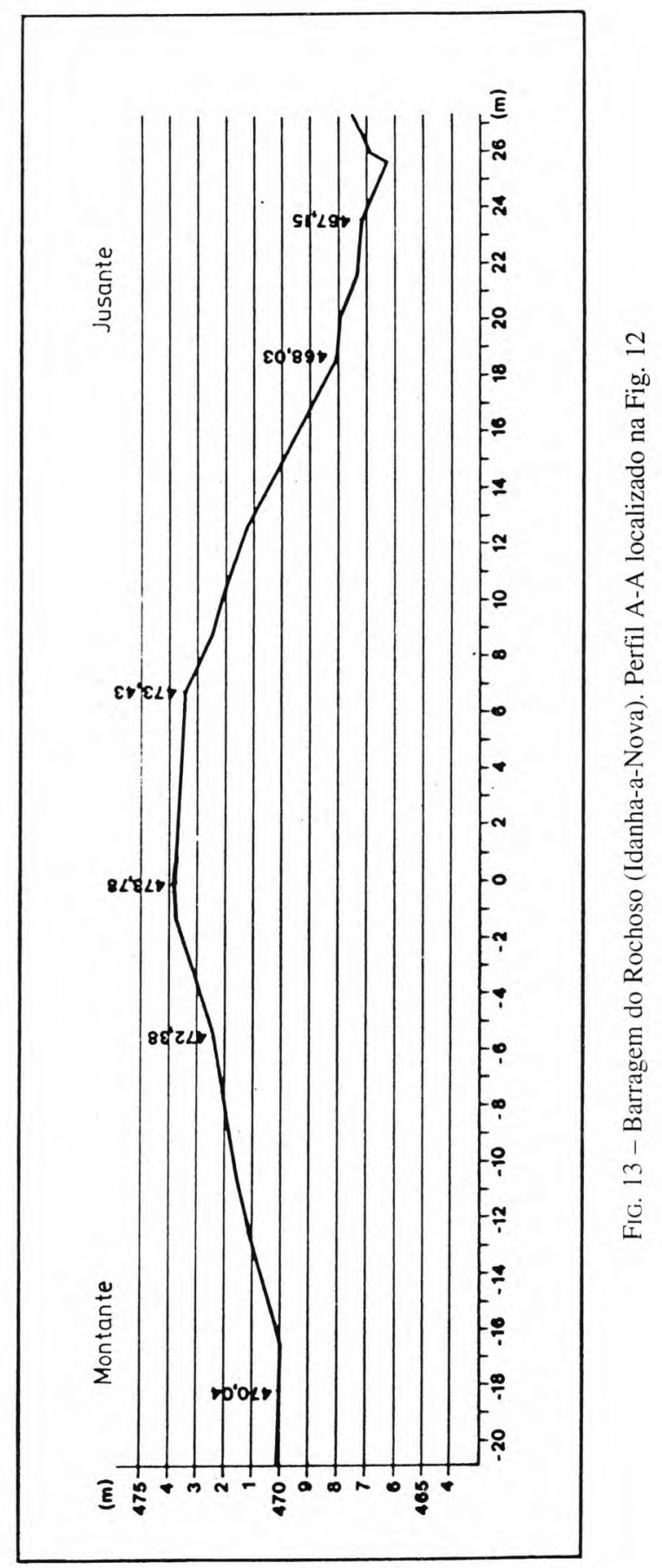




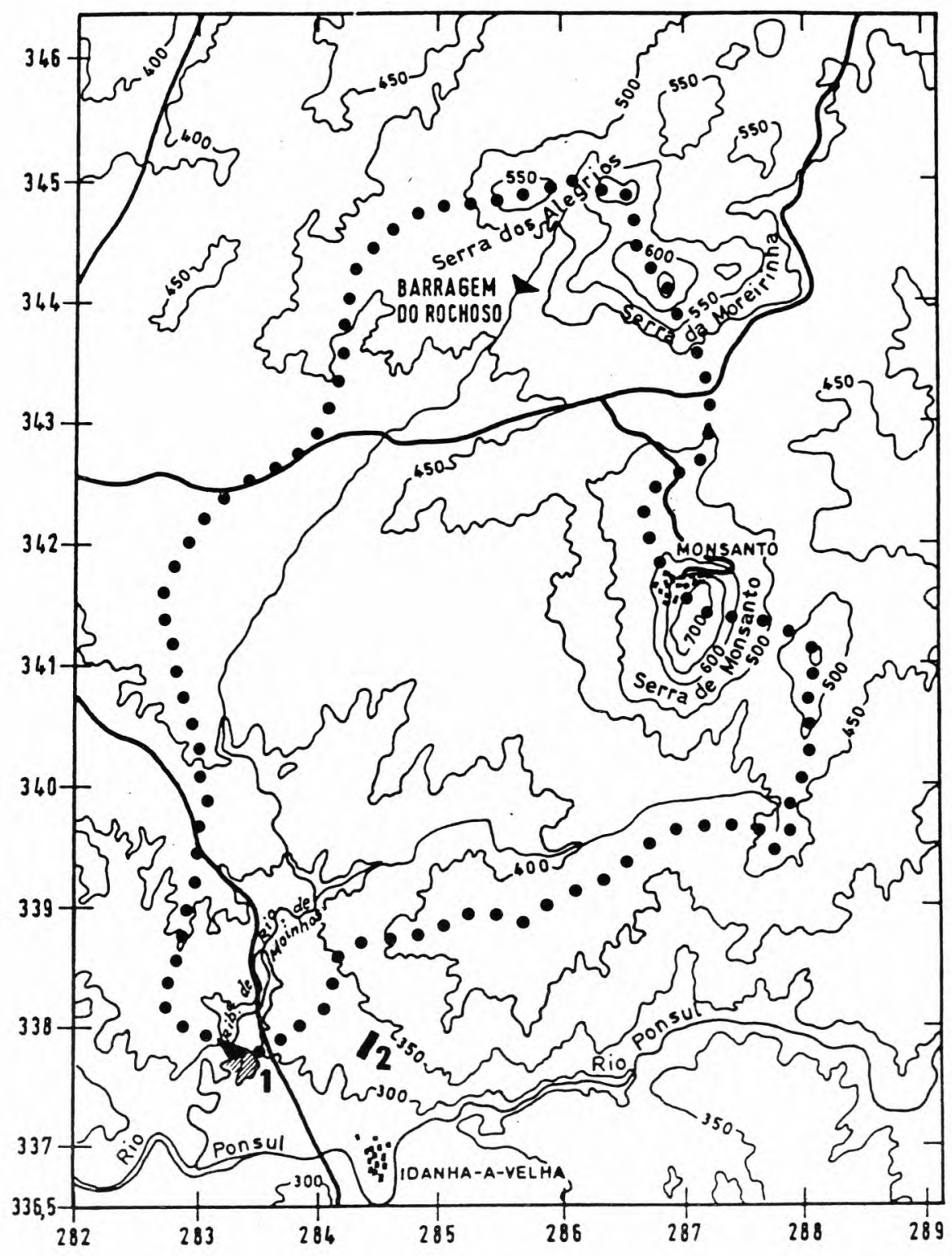

FIG. 14 - Barragem da Egitânia (Idanha-a-Nova). Localização e bacia hidrográfica 1 - Villa 2 - Vestígios de mineração 


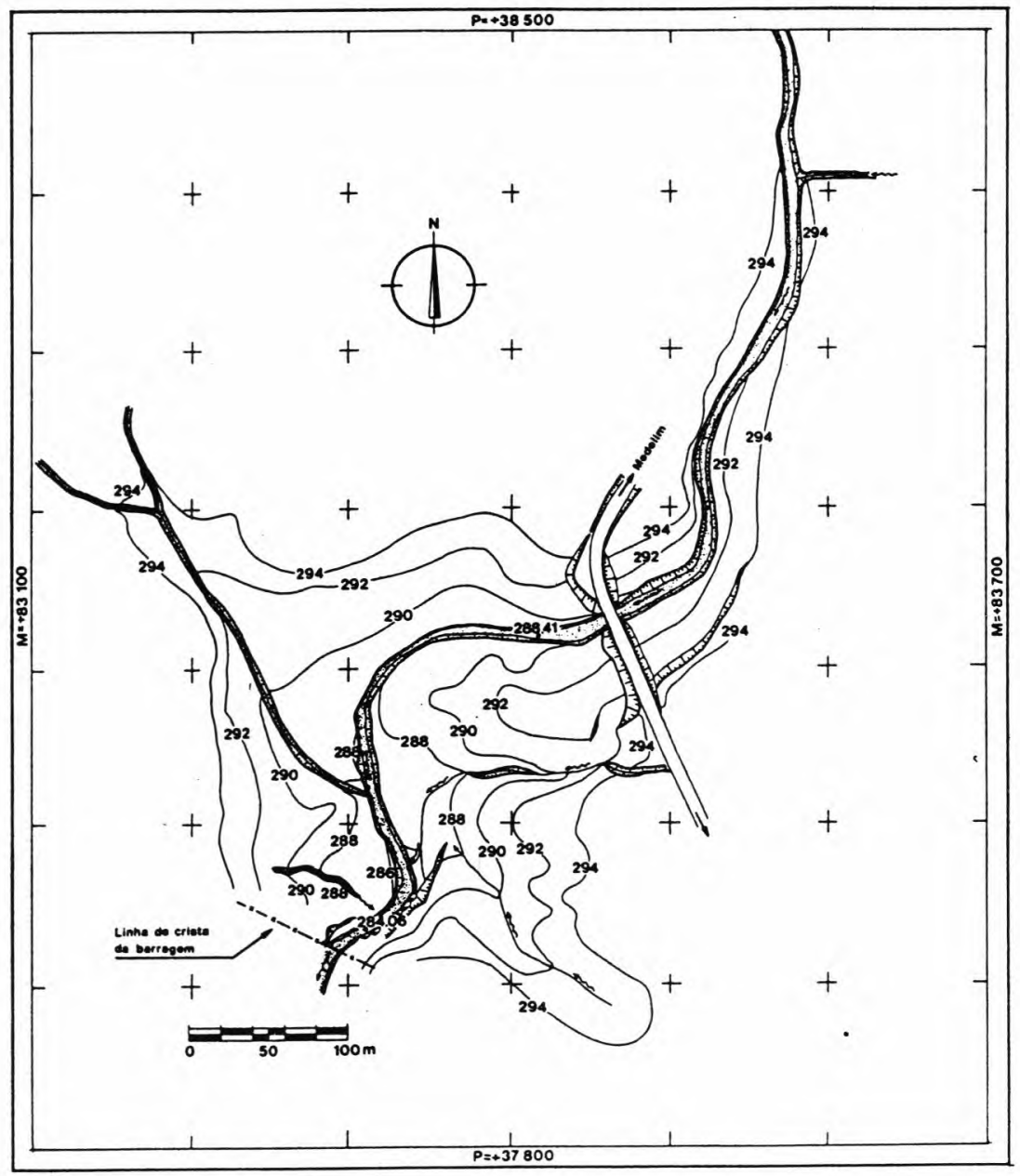

FIG. 15 - Barragem da Egitânia (Idanha-a-Nova). Planta da albufeira 


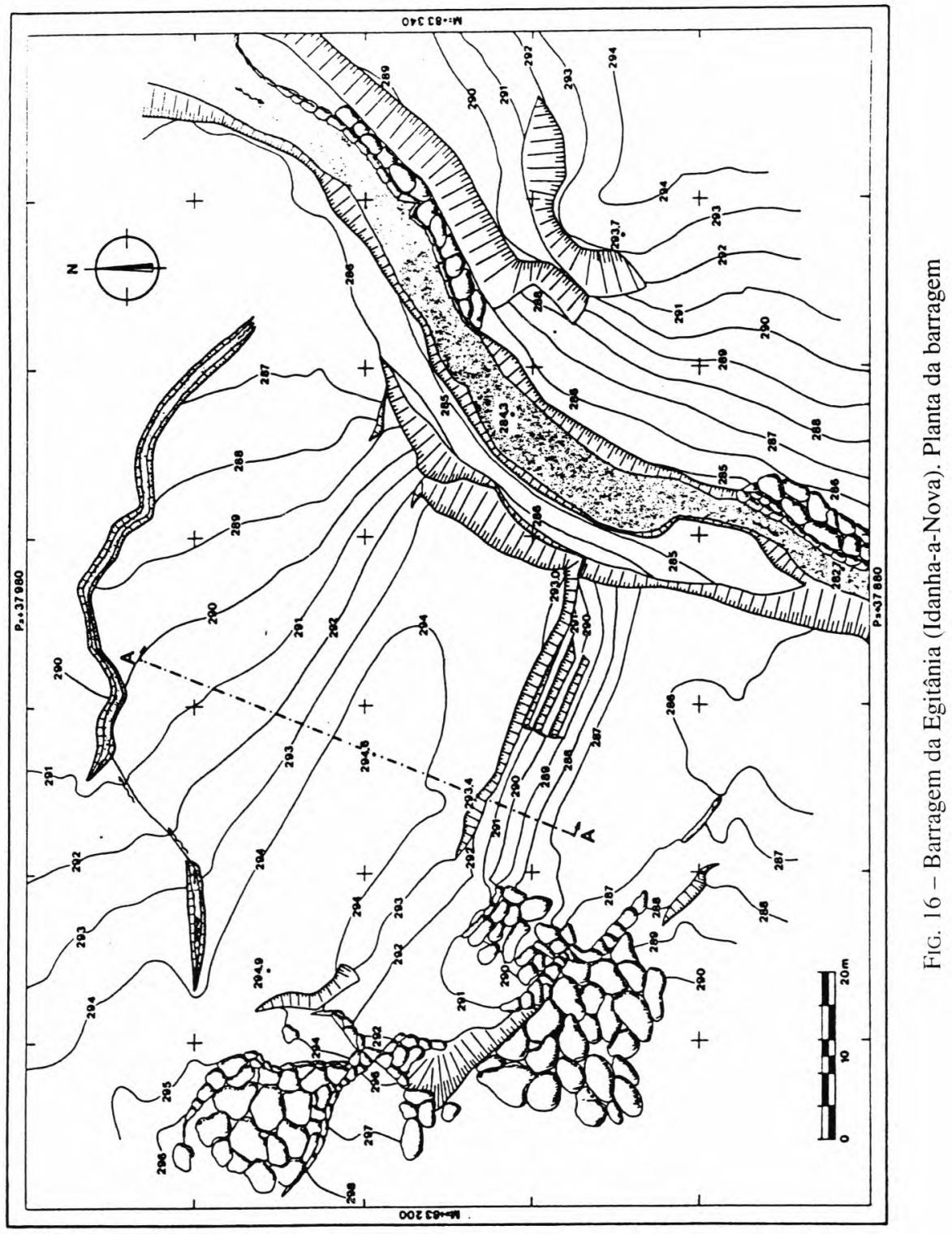




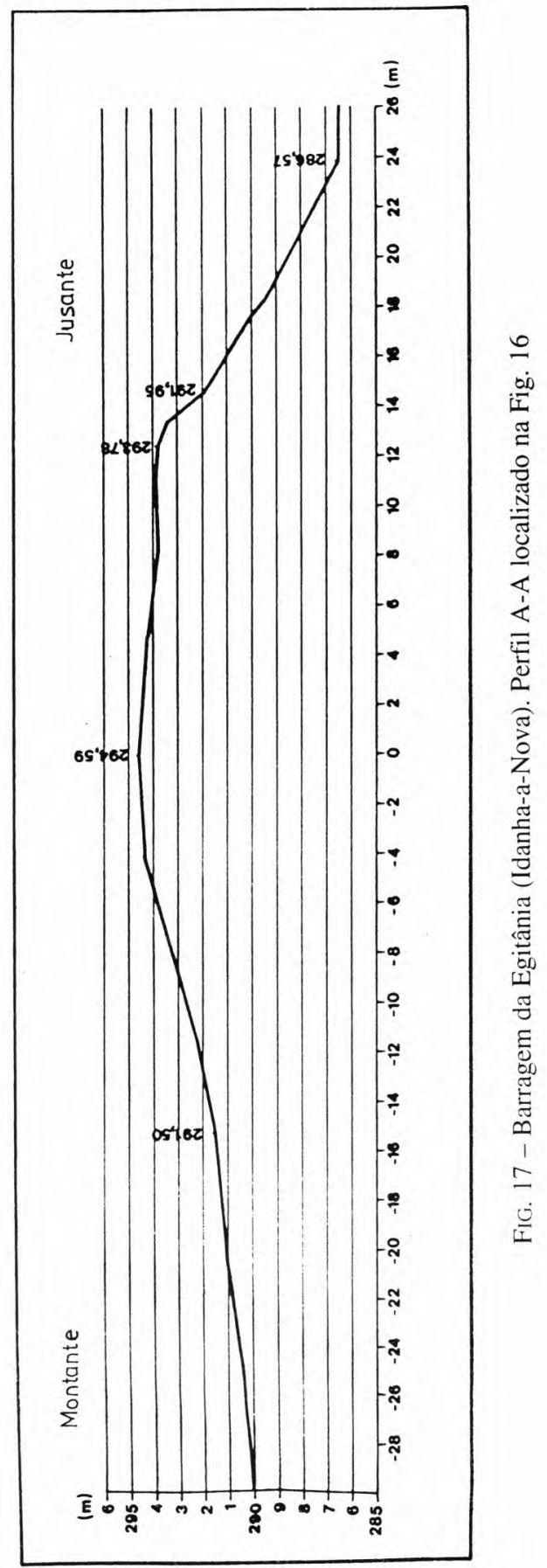




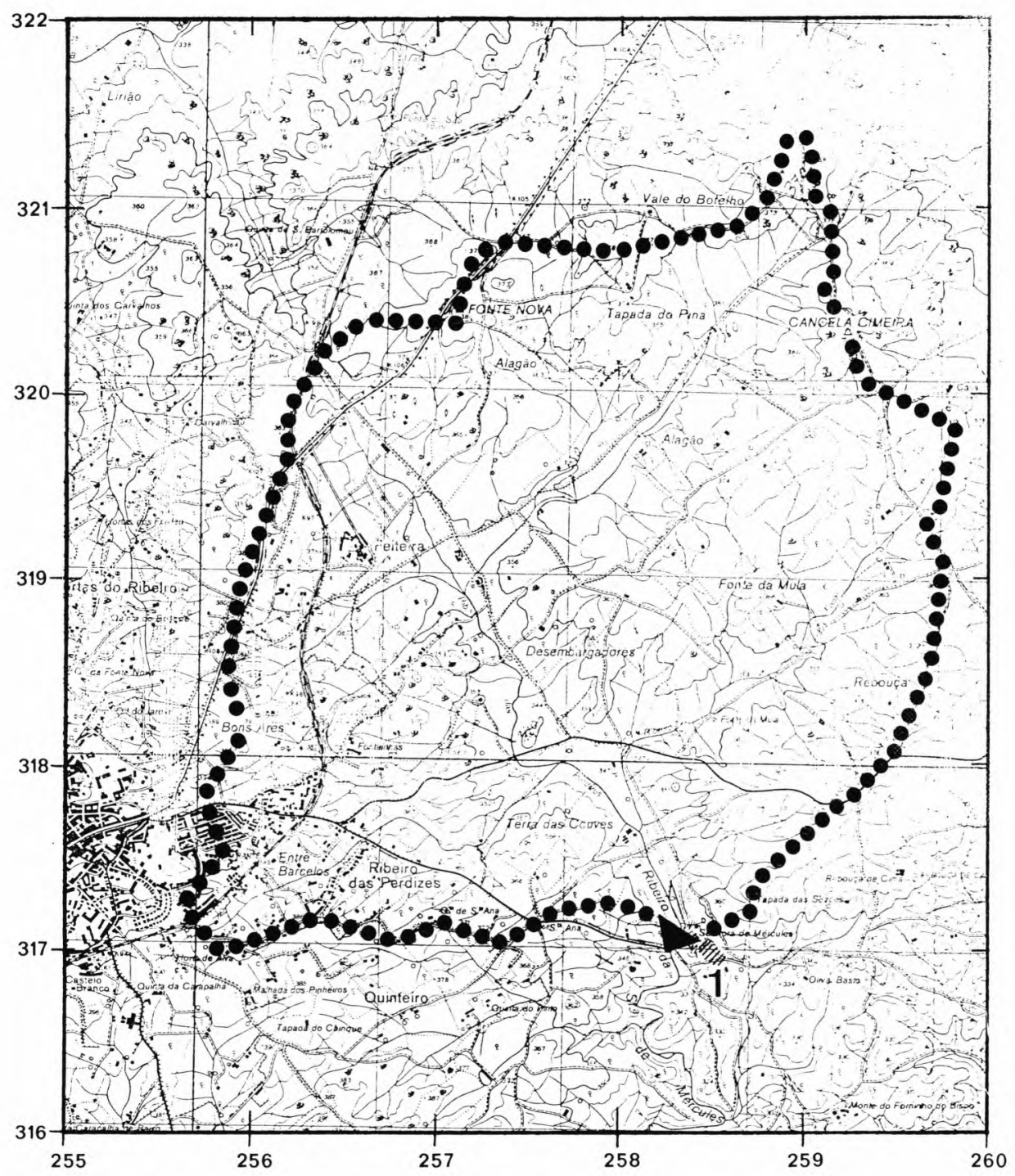

FIG. 18 - Barragem da Nossa Senhora de Mércoles (Castelo Branco). Localização e bacia hidrográfica

1 - Vestígios romanos 


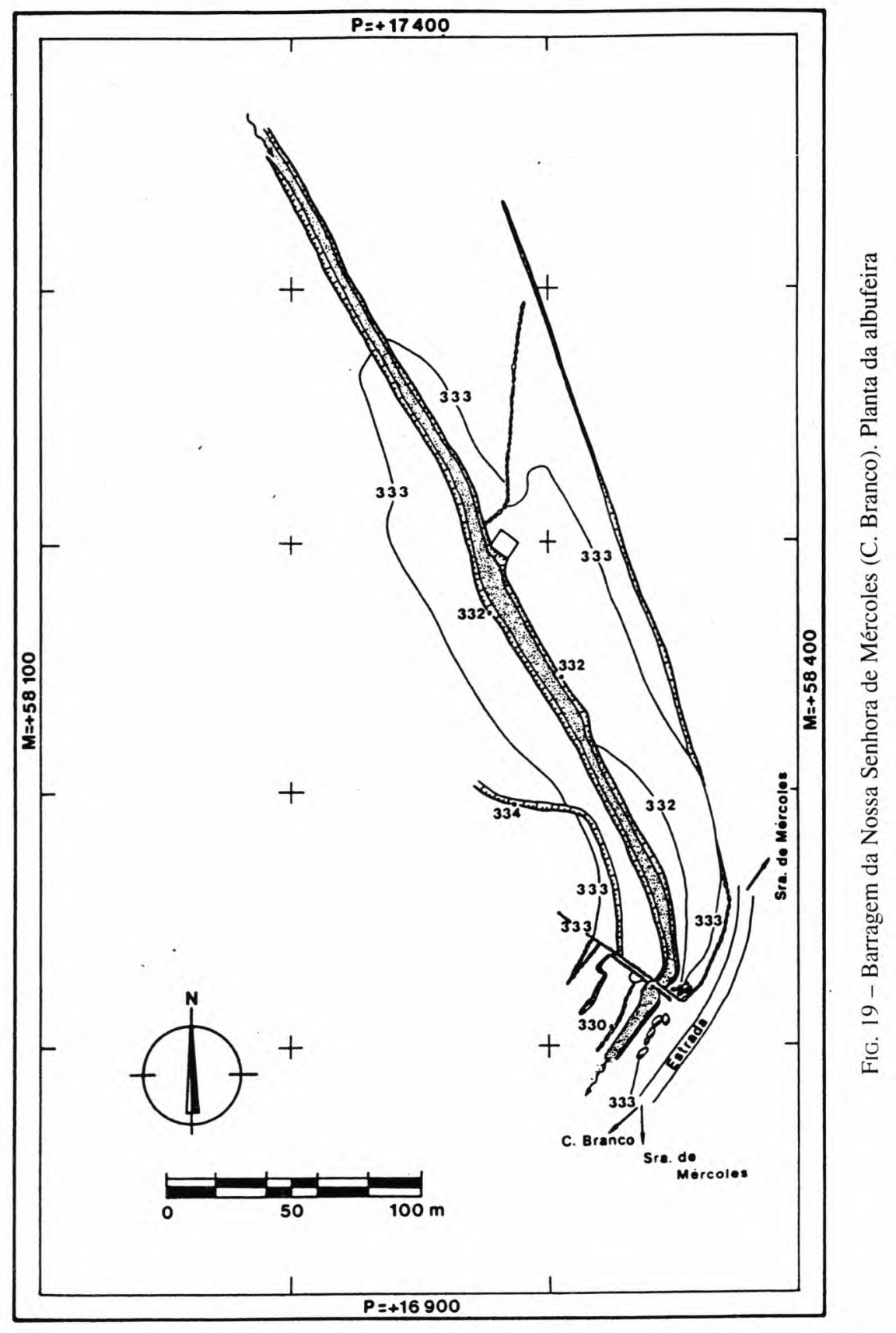




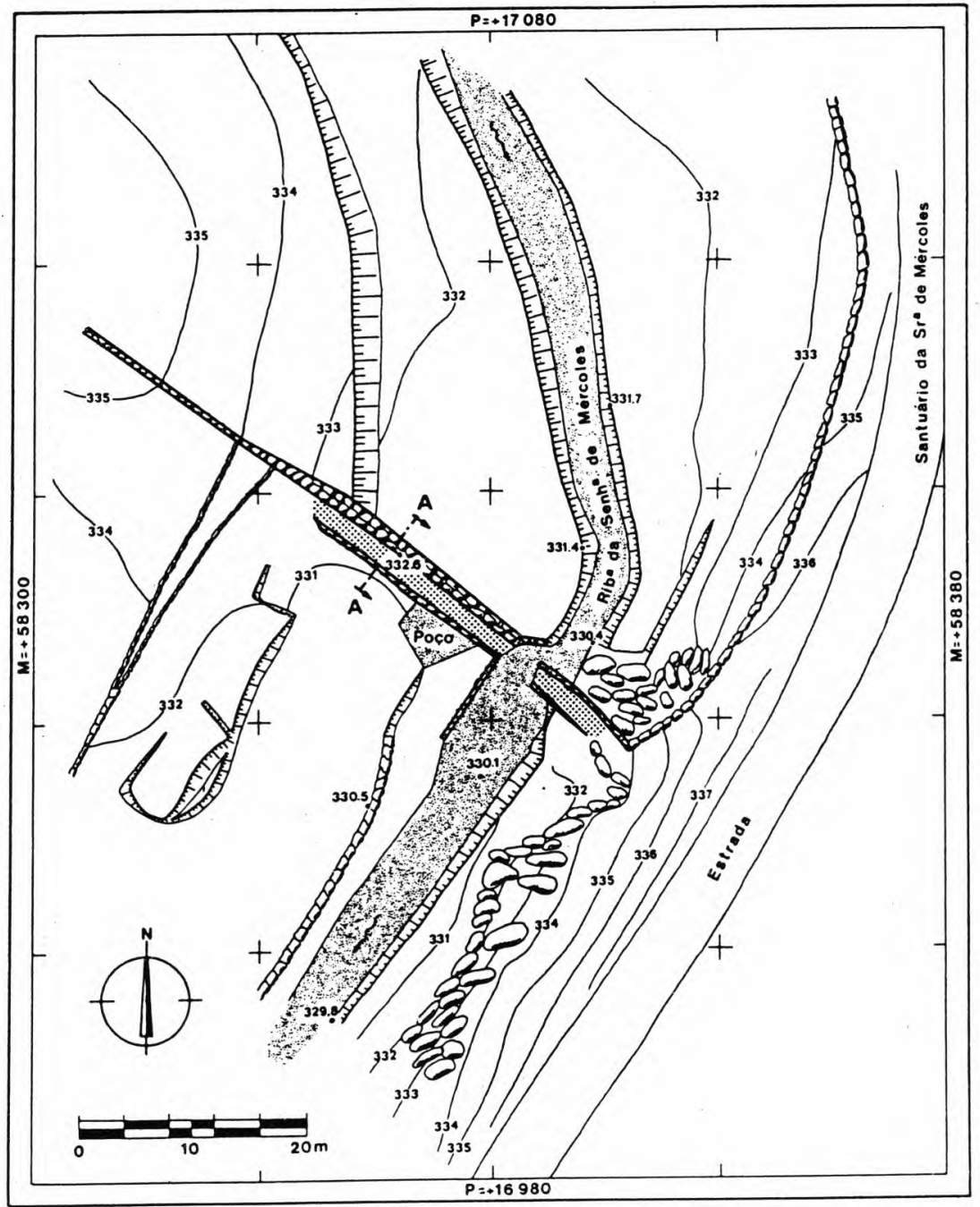

Fig. 20 - Barragem da de Nossa Senhora de Mércoles(Castelo Branco). Planta da barragem 


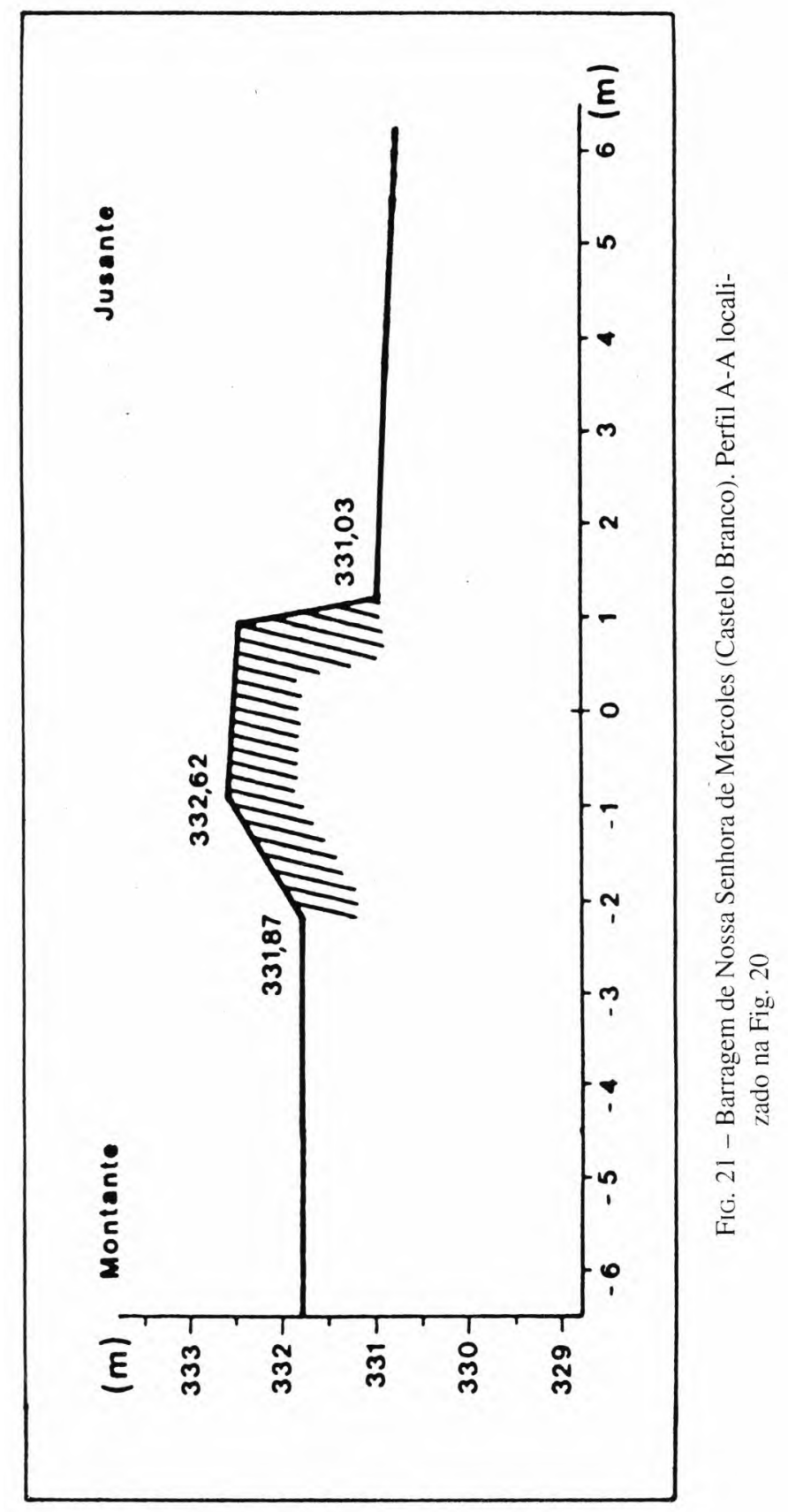




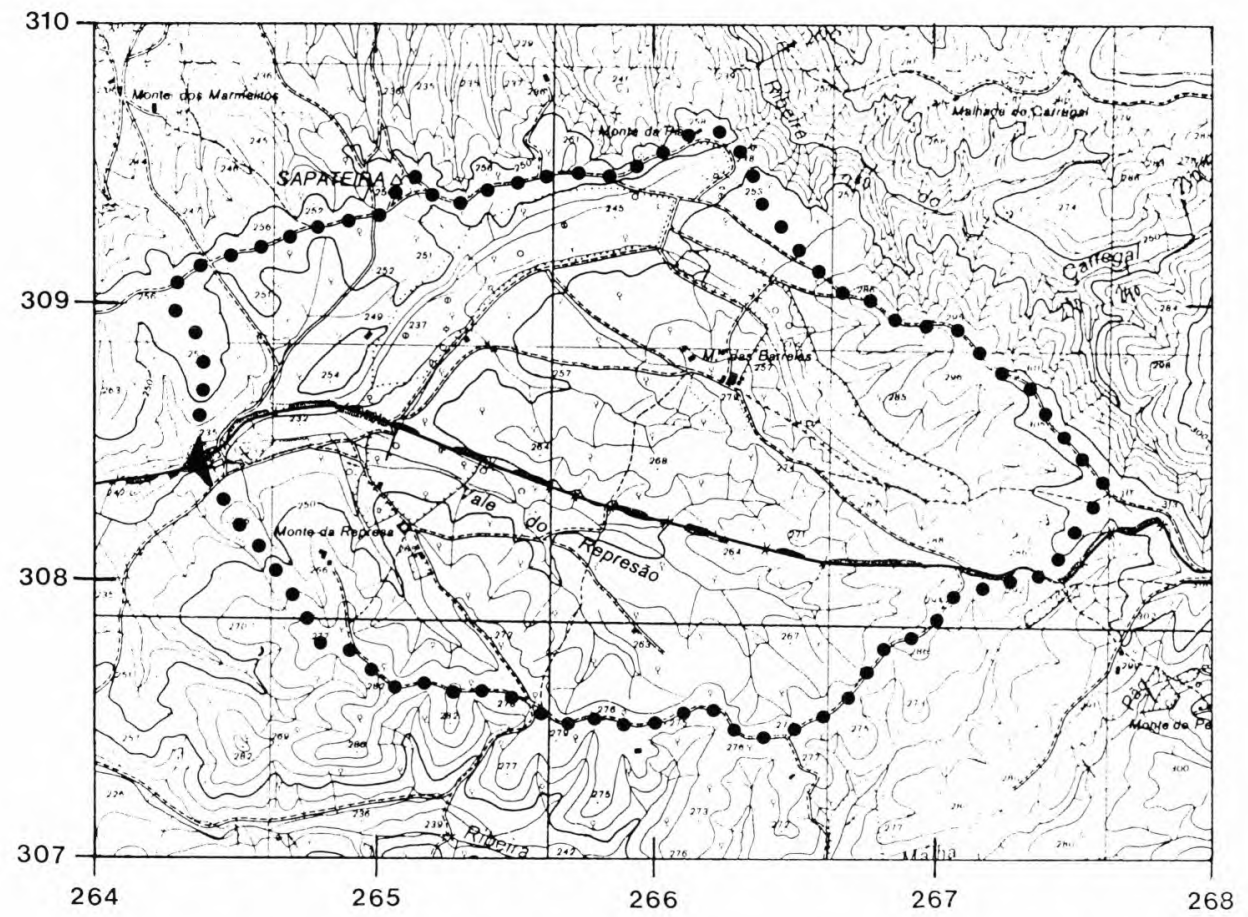

FIG. 22 - Barragem de Monforte (Castelo Branco). Localização e bacia hidrográfica 


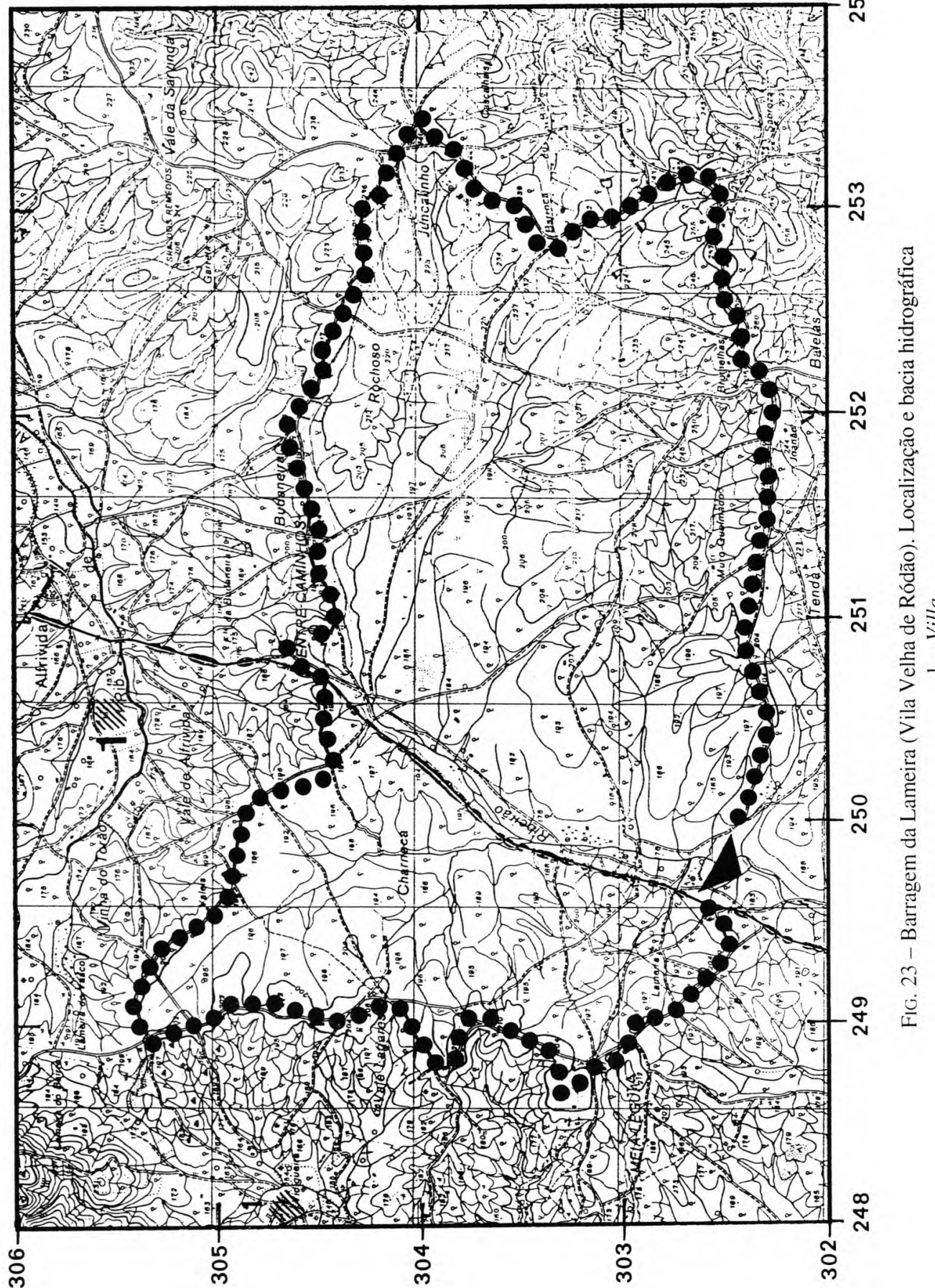




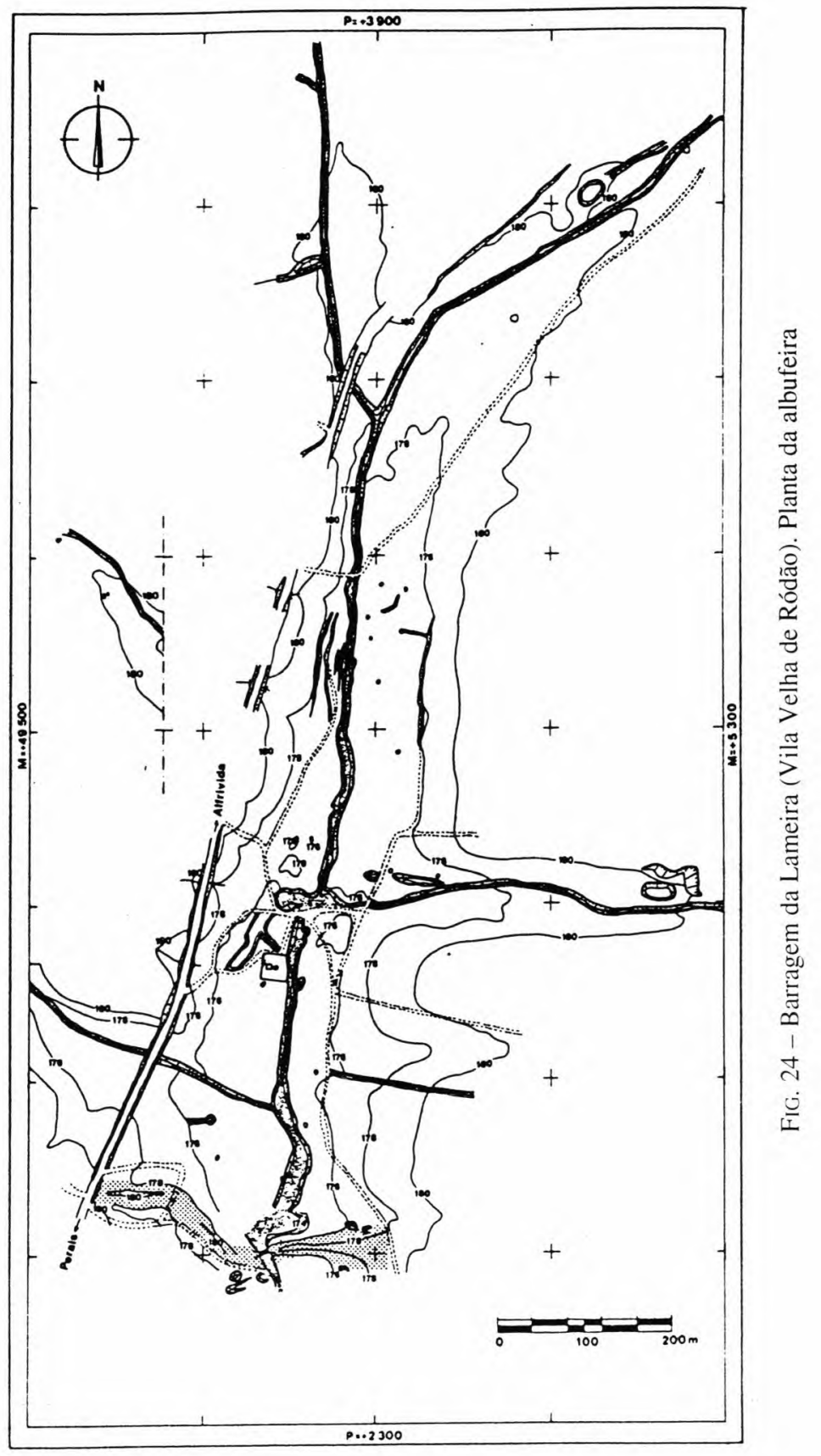




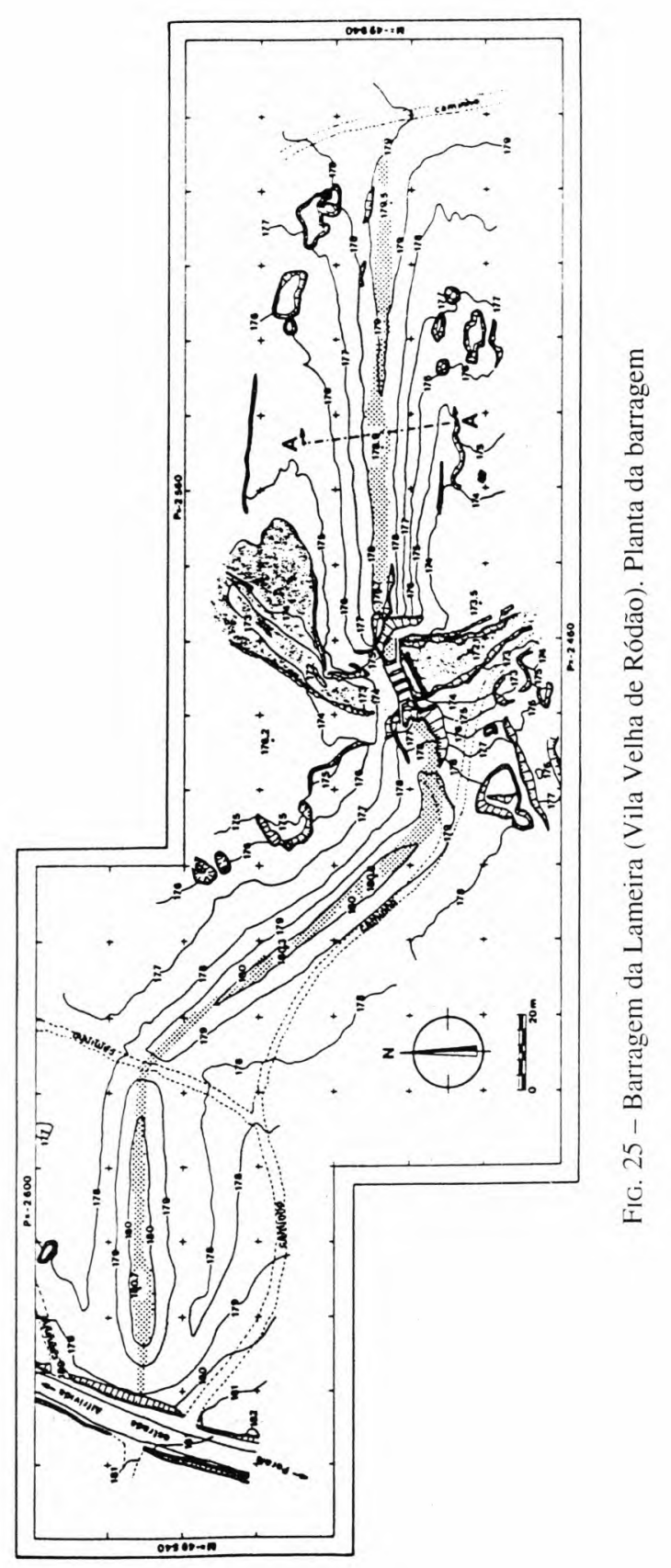




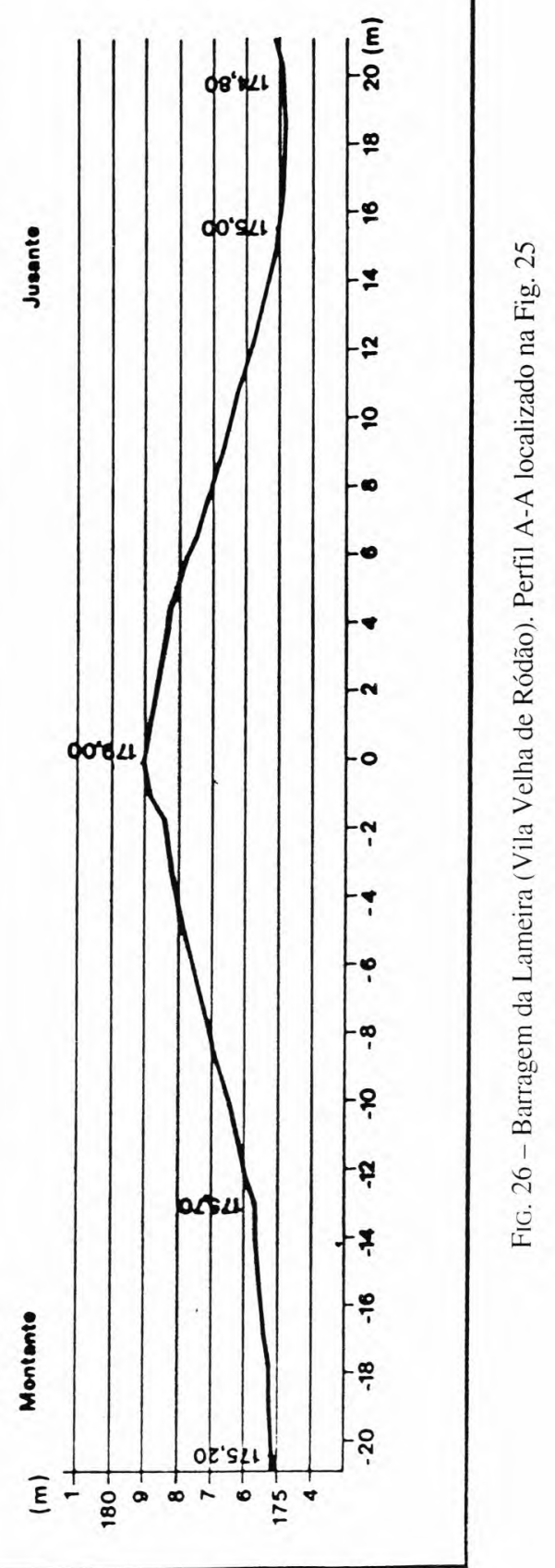




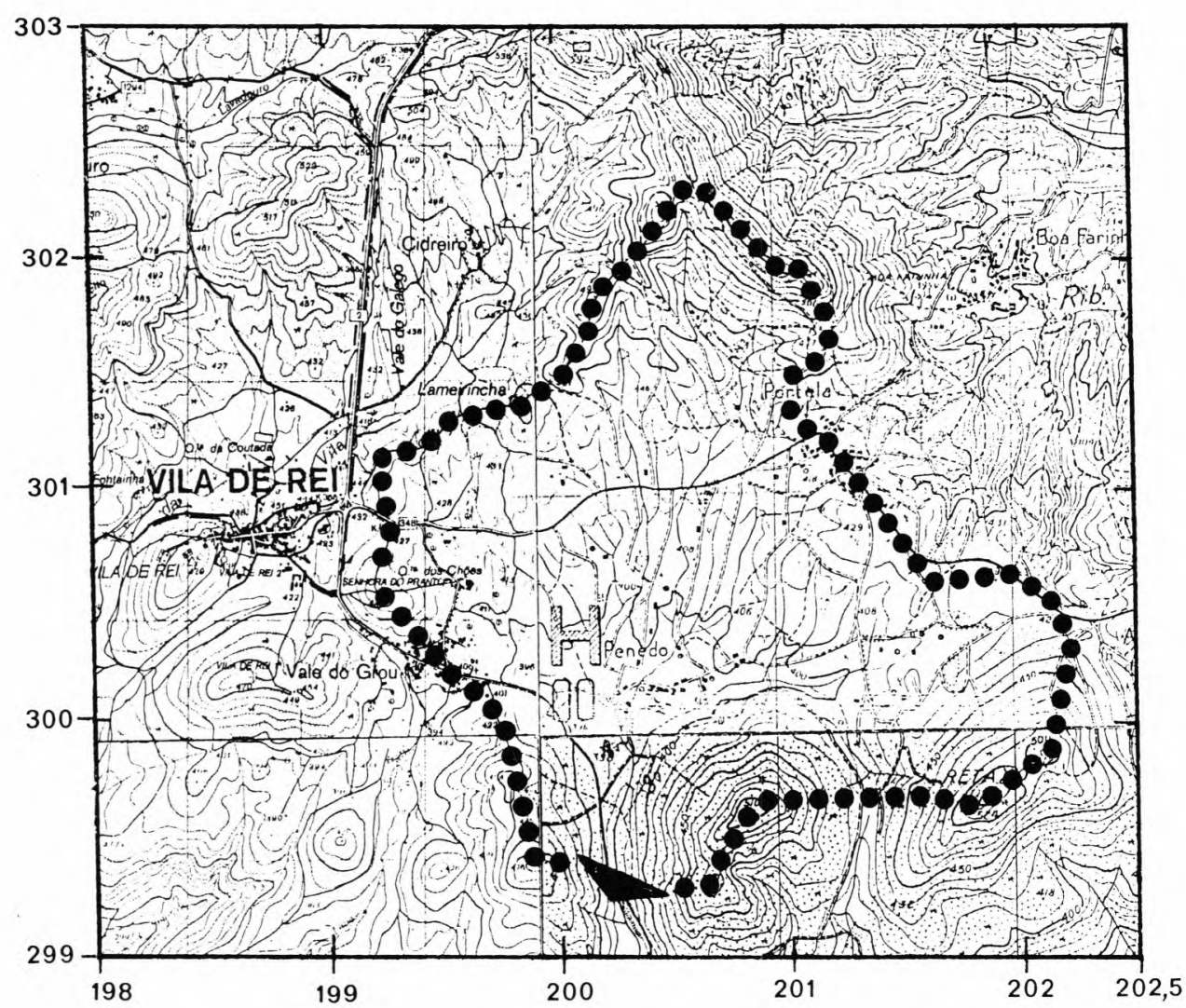

FIG. 27 - Barragem do Souto do Penedo (Vila de Rei). Localização e bacia hidrográfica 


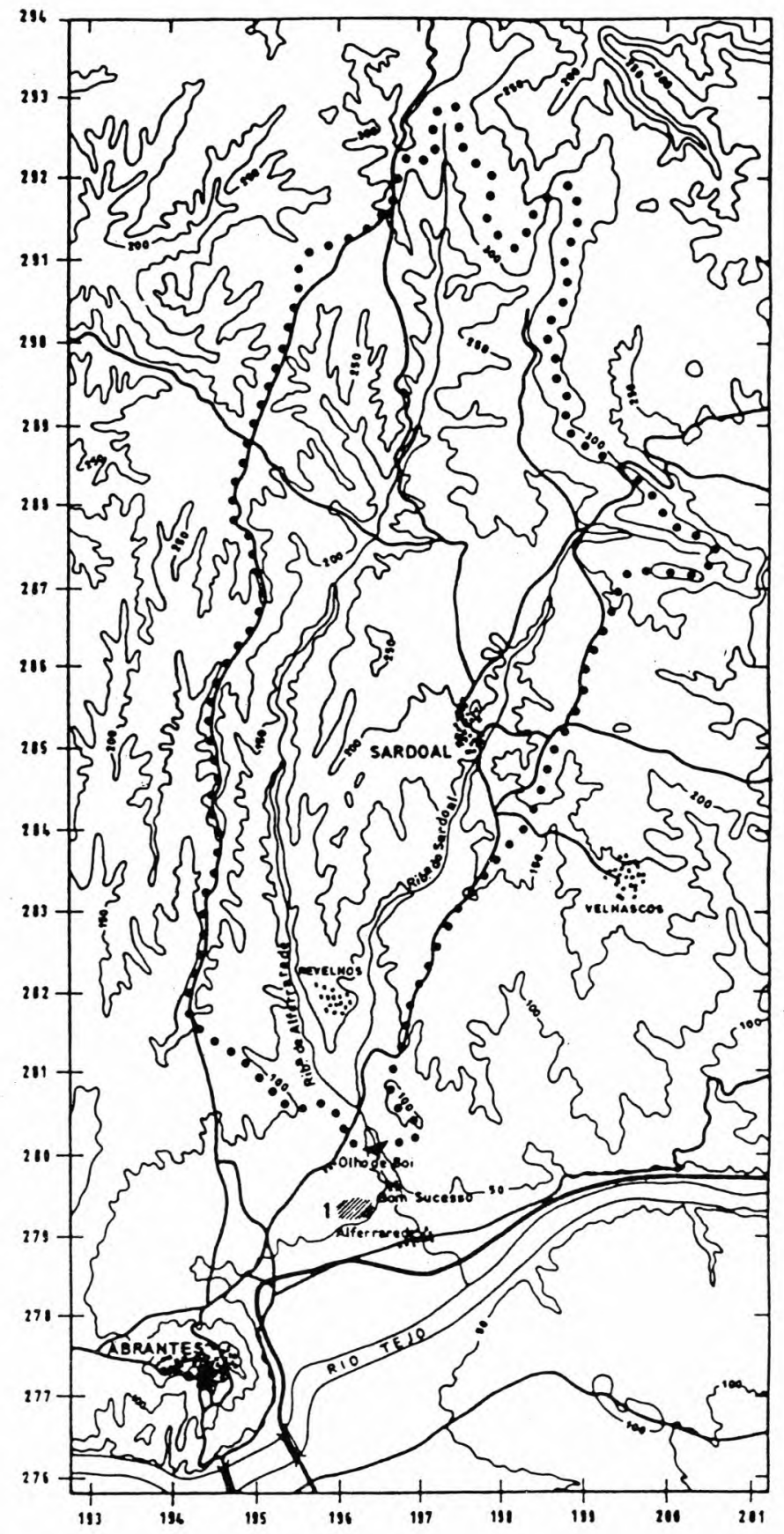

FIG. 28 - Barragem de Alferrarede (Abrantes). Localização e bacia hidrográfica 1 - Villa 


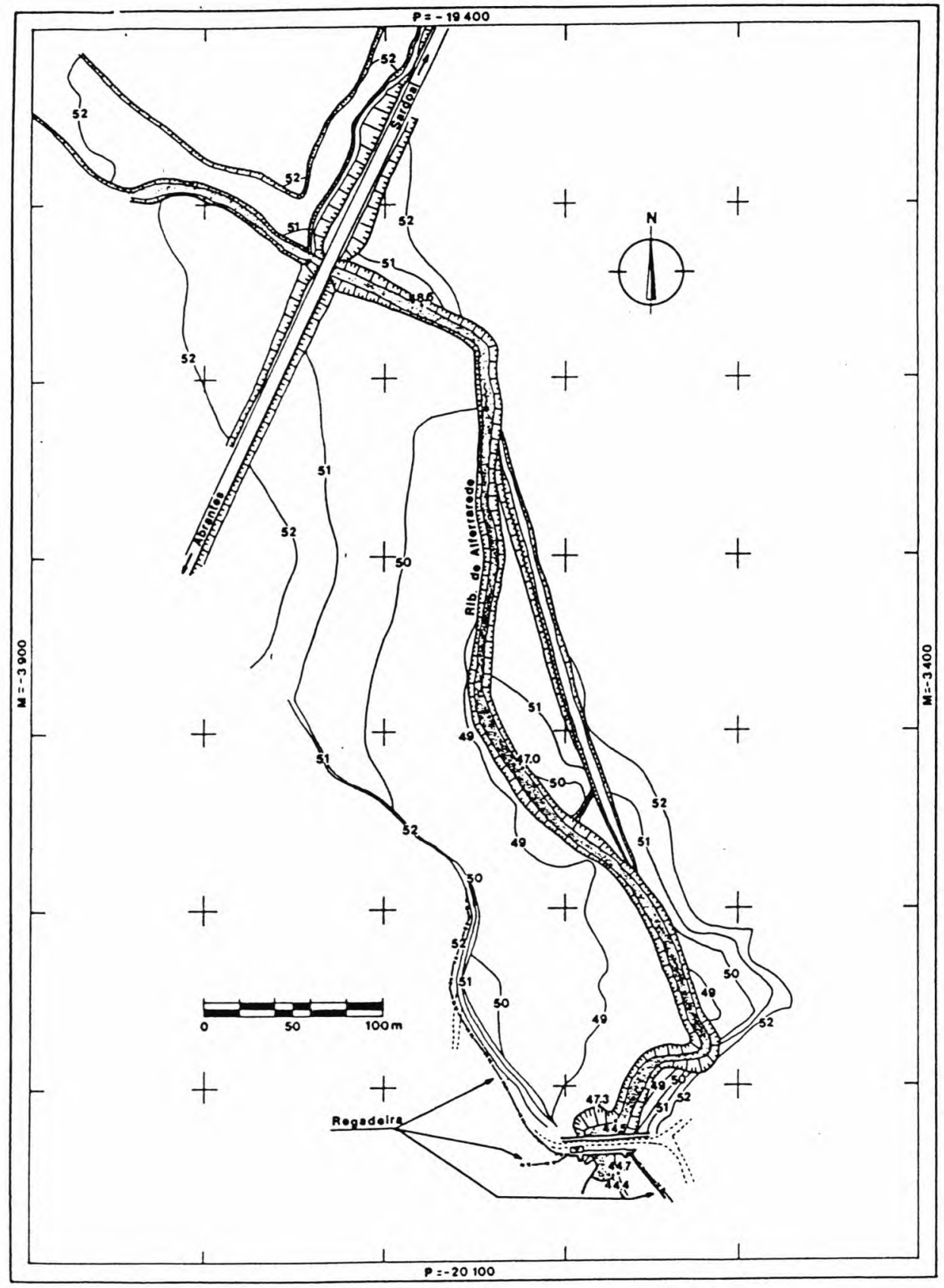

FIG. 29 - Barragem de Alferrarede (Abrantes). Planta da albufeira 


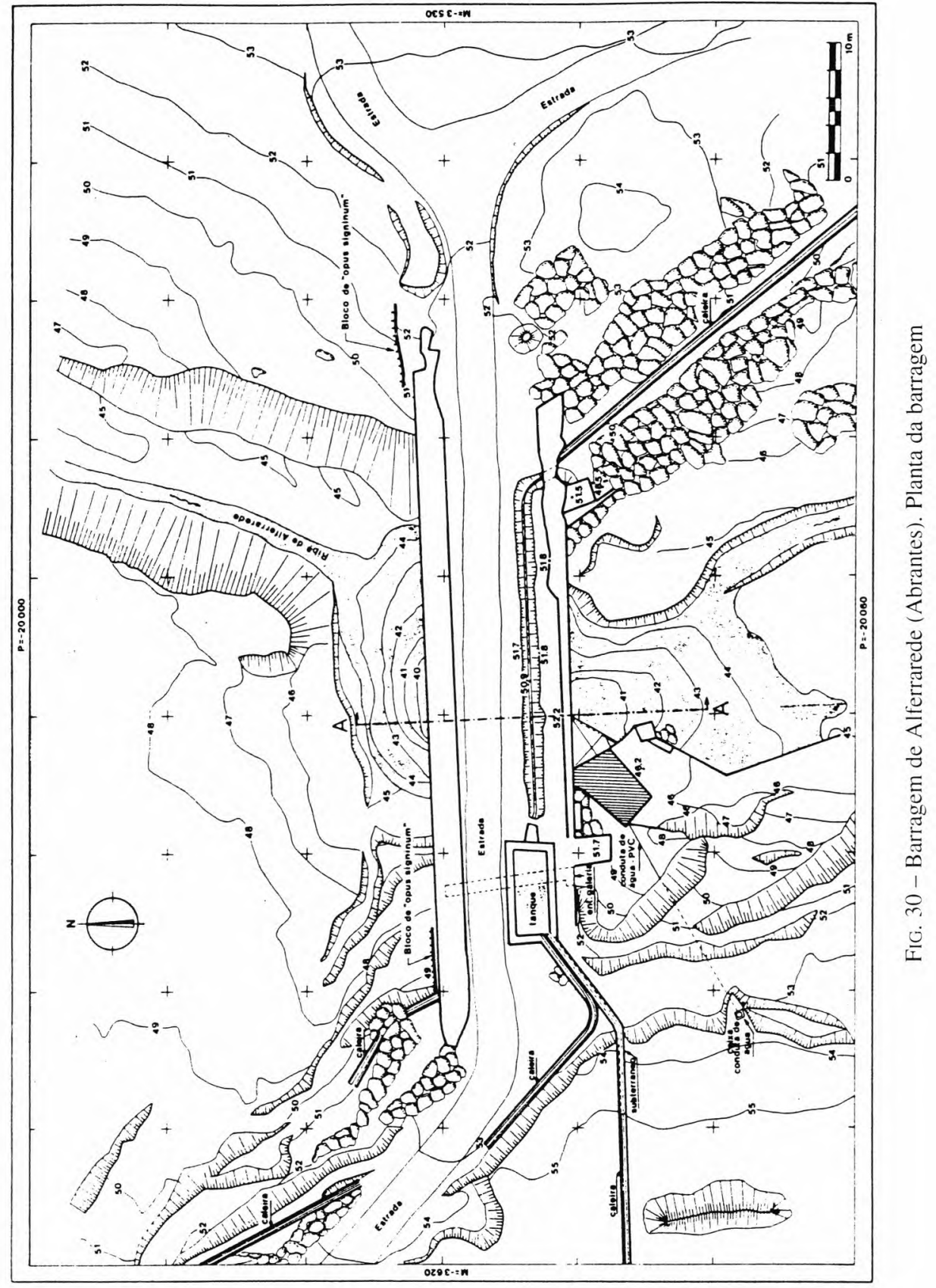




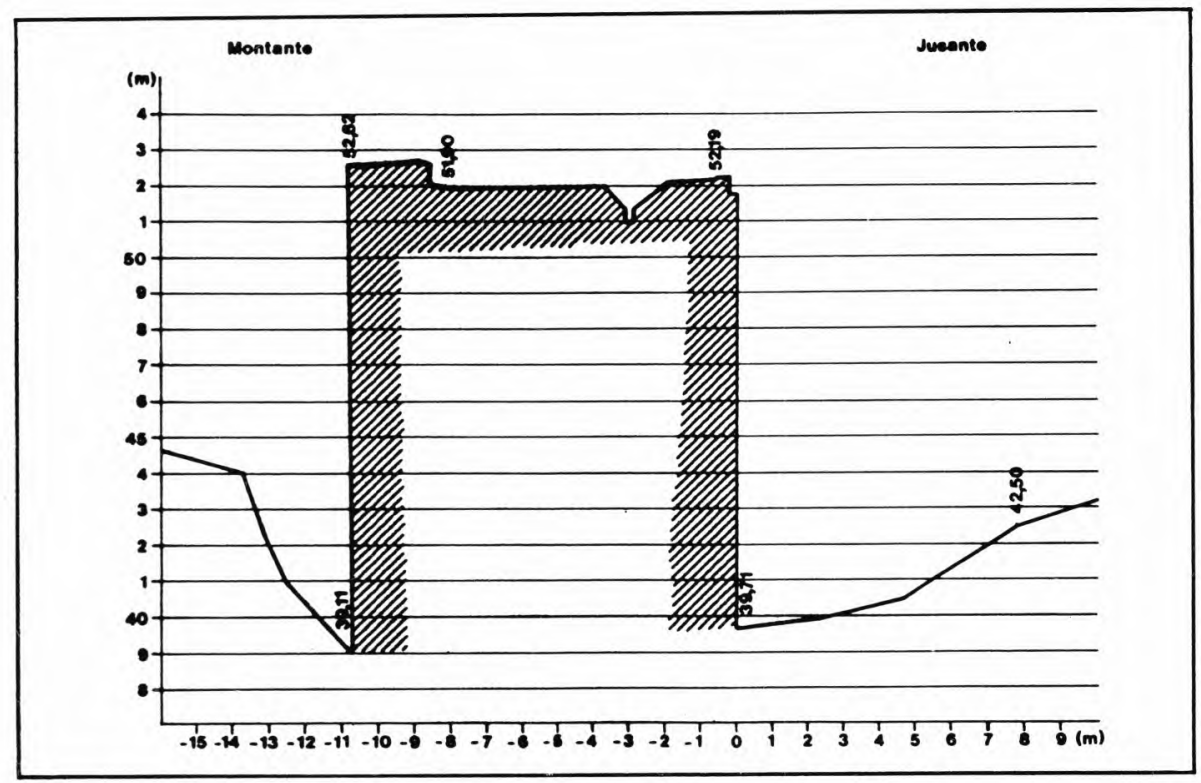

FIG. 31 - Barragem de Alferrarede (Abrantes). Perfil A-A localizado na Fig. 30 


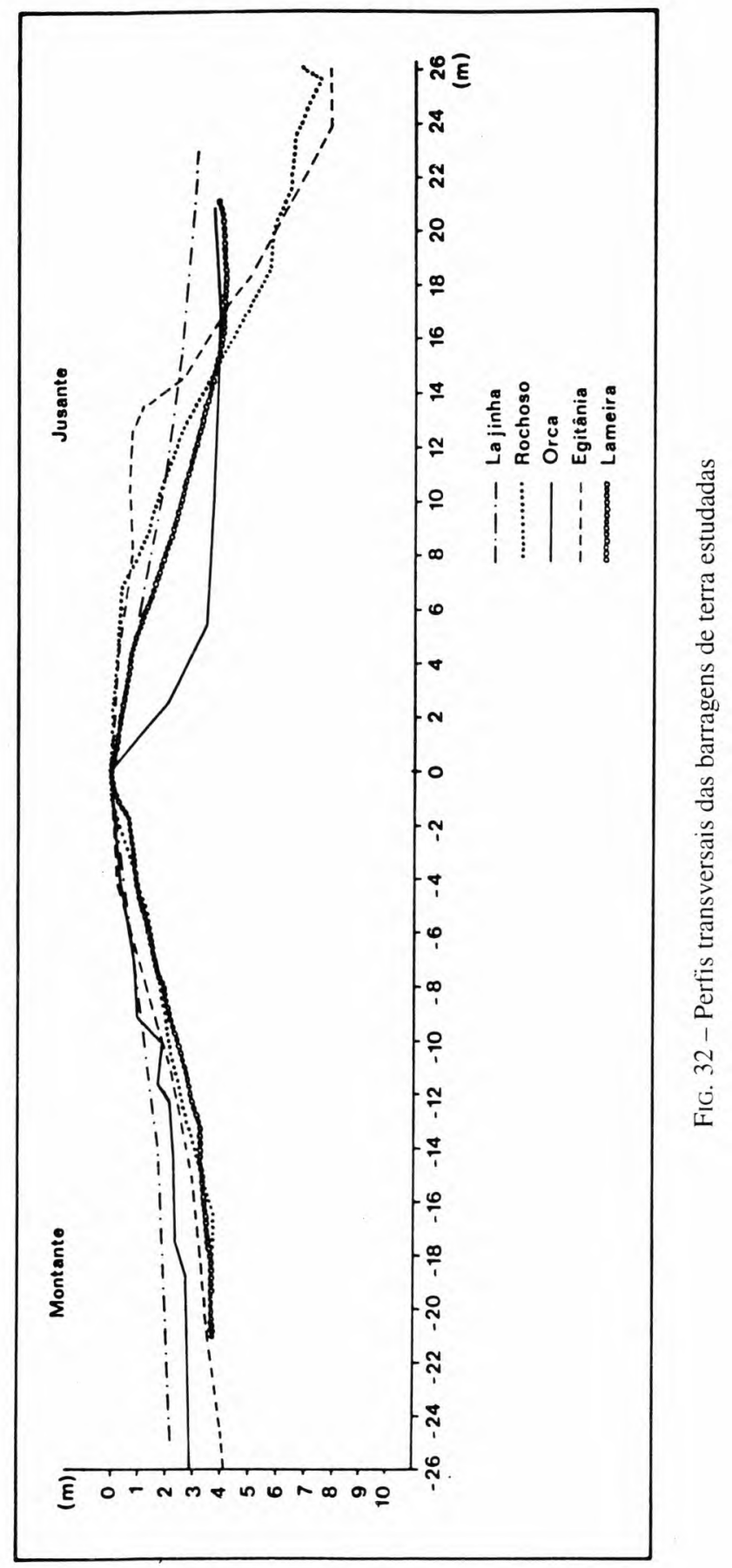




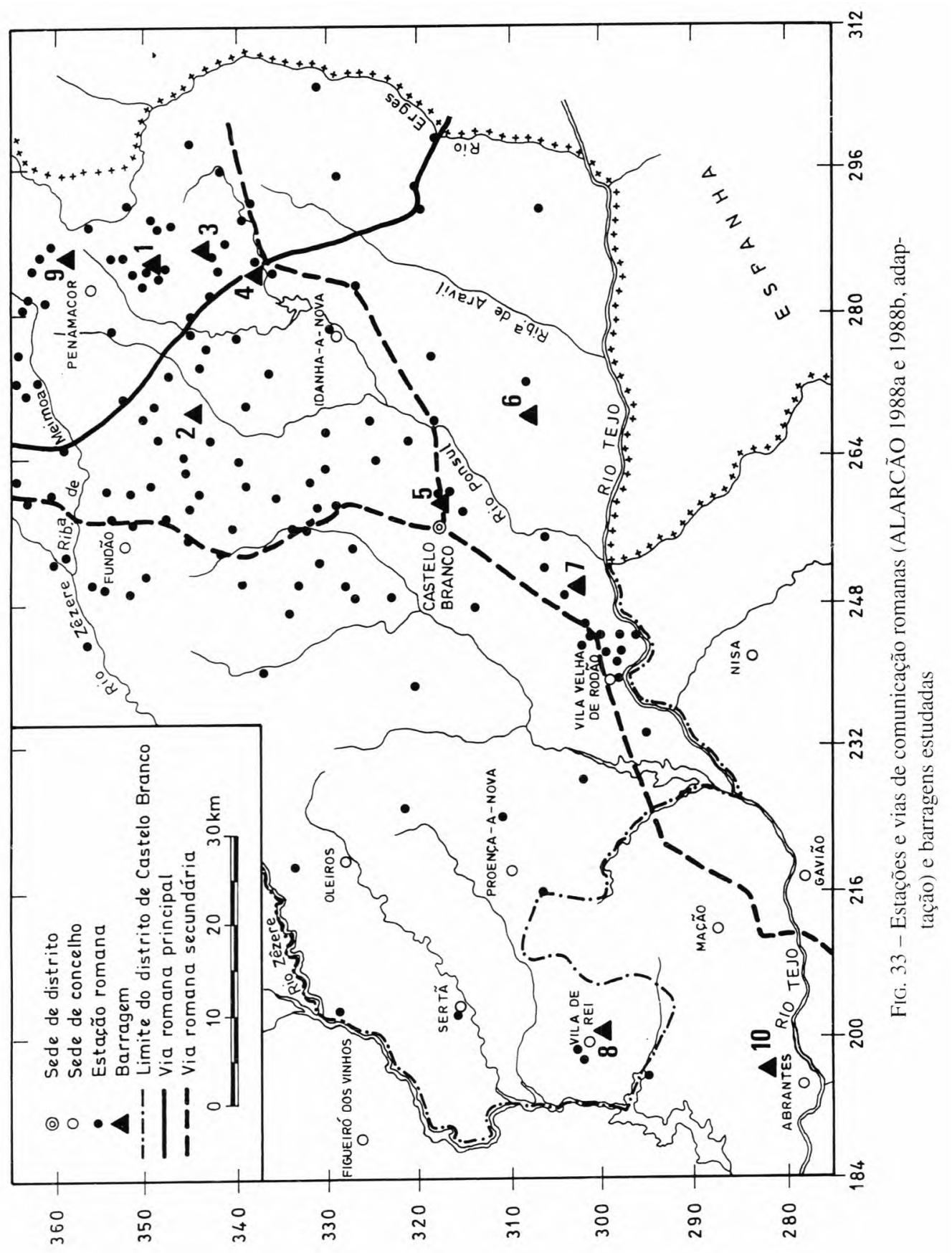




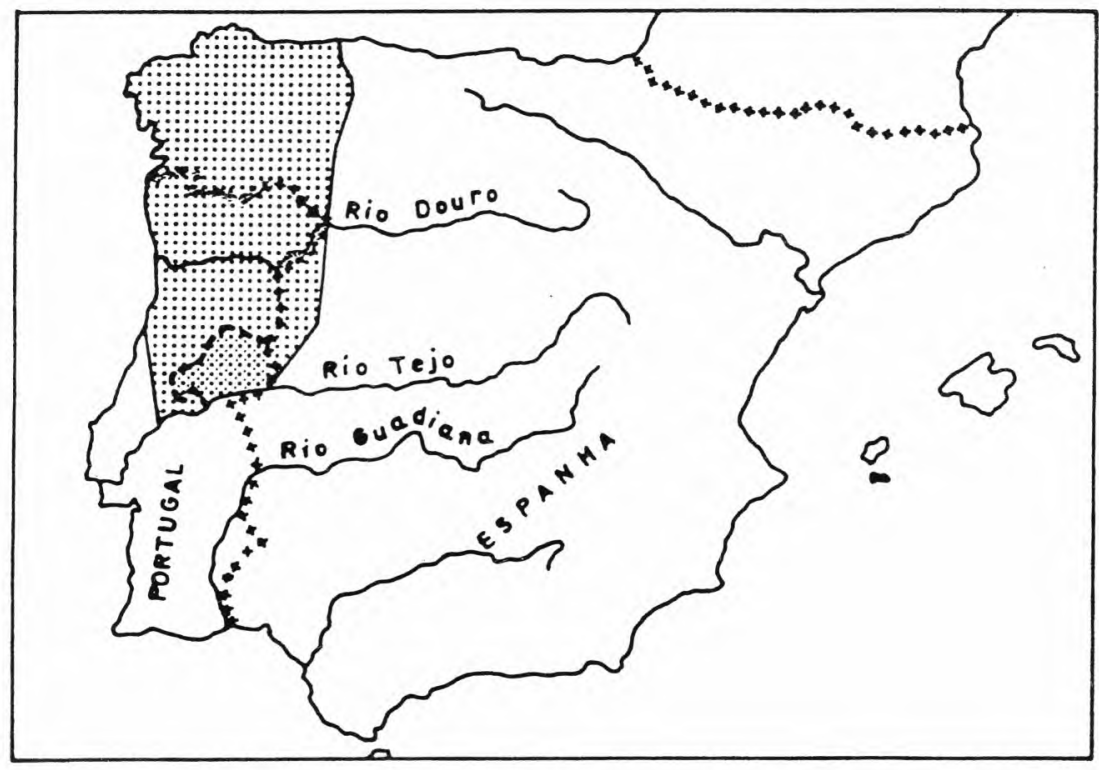

FIG. 34 - Região aurífera do Noroeste da Península Ibérica minerada pelos romanos, com delimitação do distrito de Castelo Branco (adaptação da Fig. 1 de DOMERGUE 1986) 


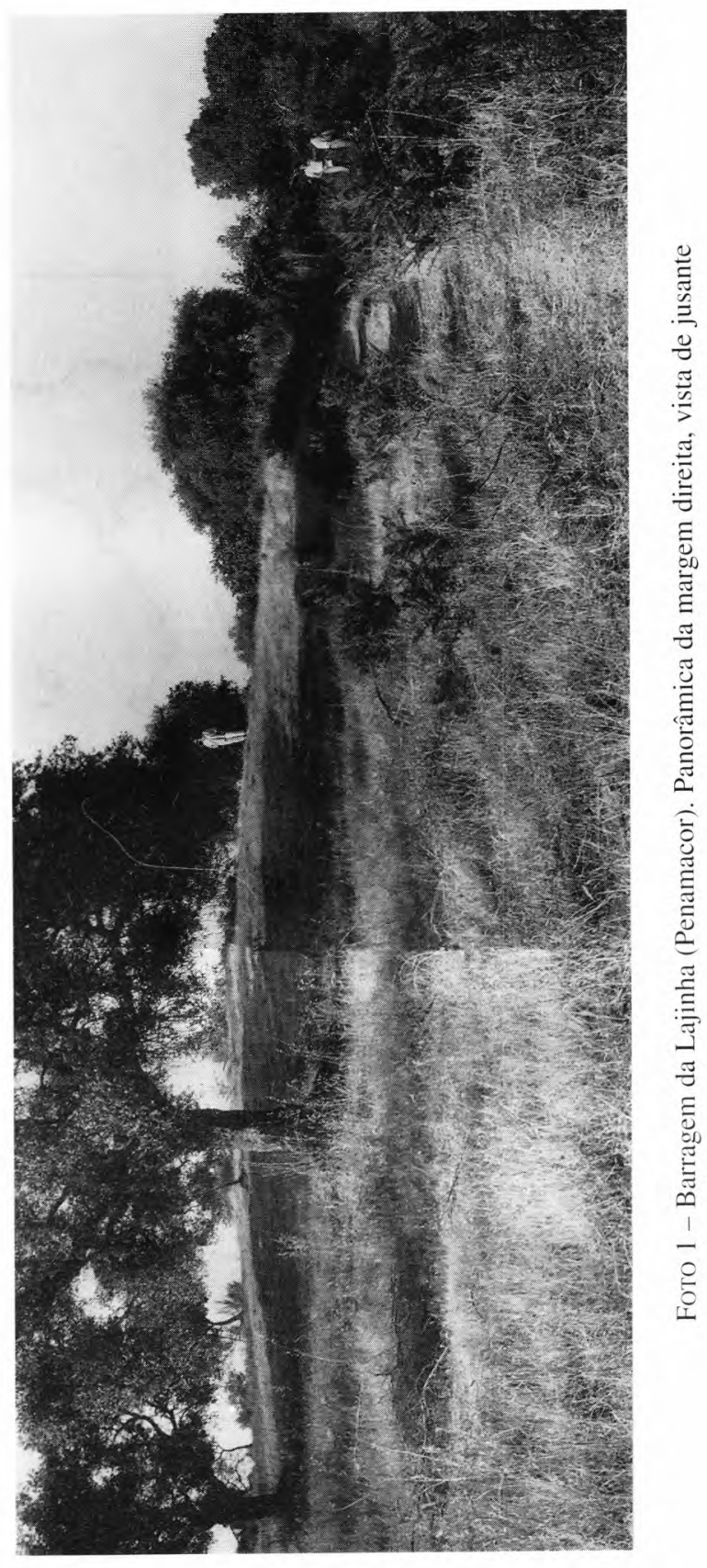




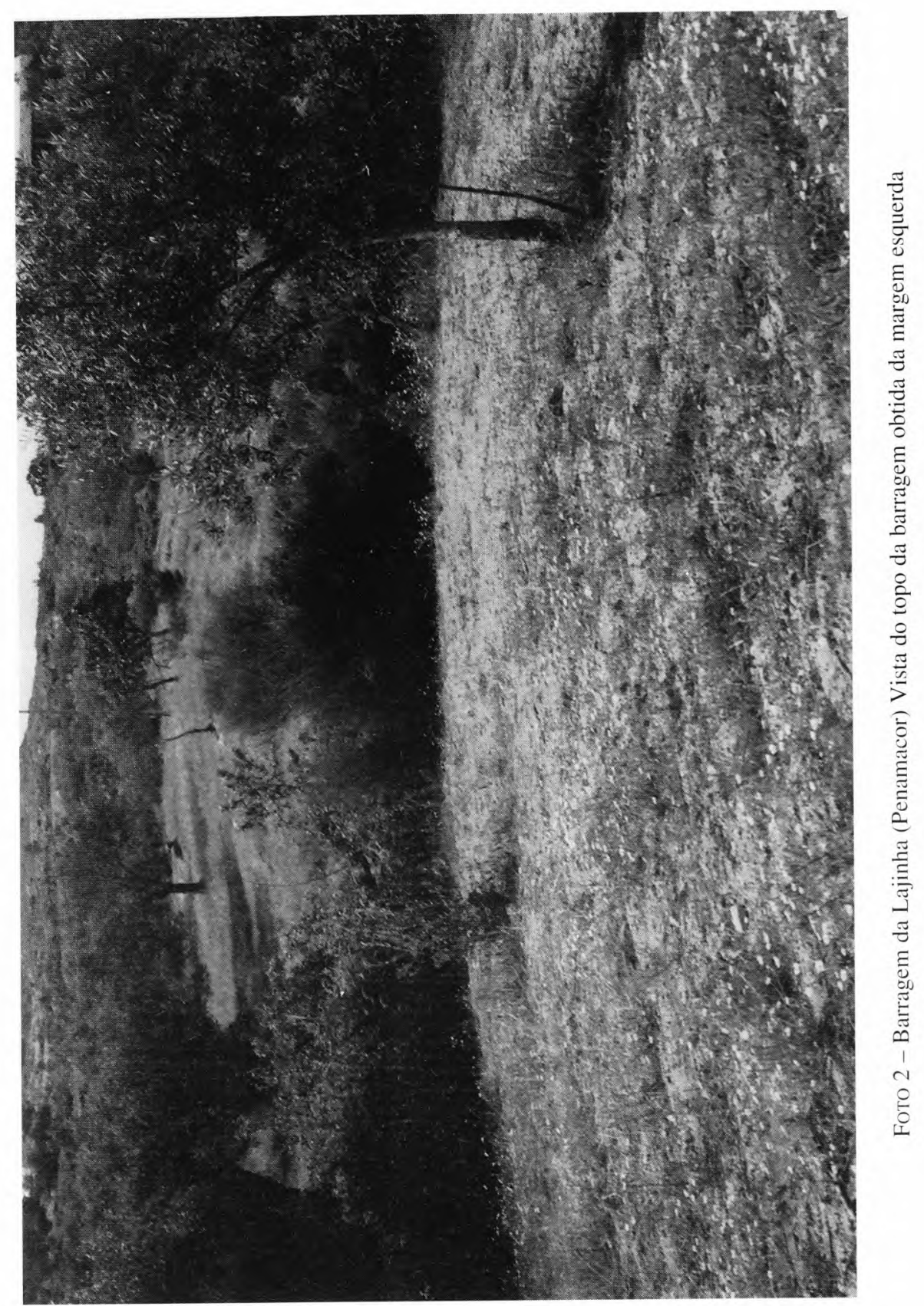




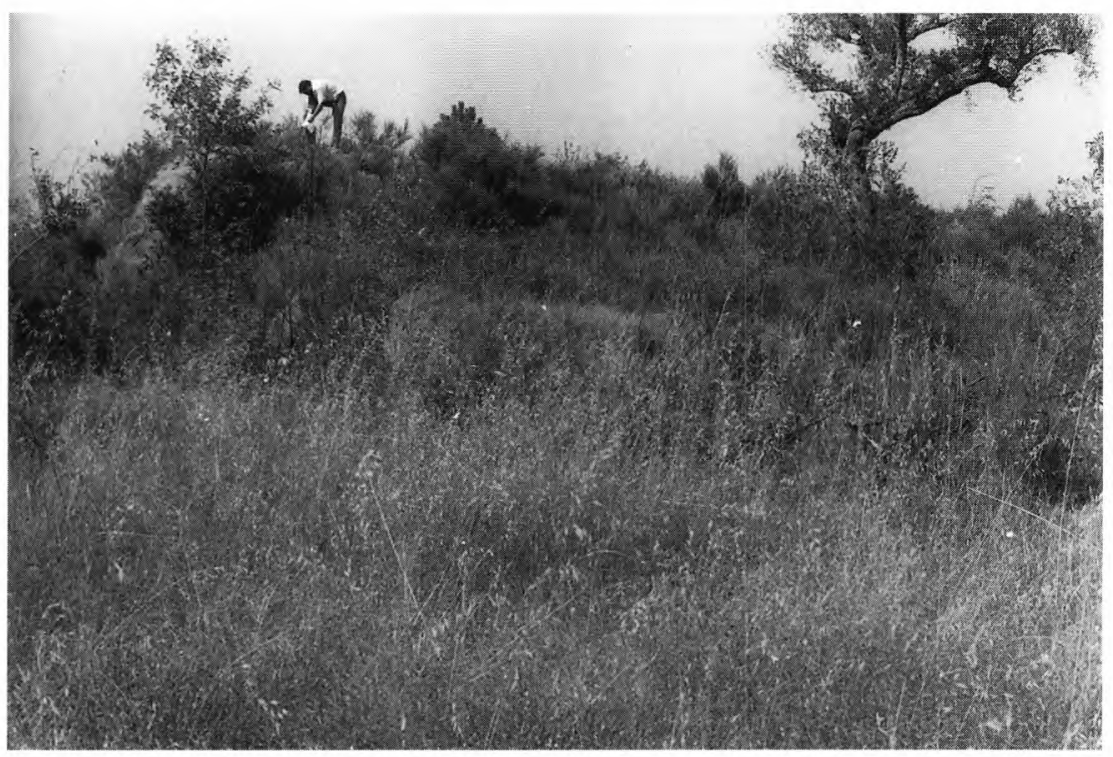

Fото 3 - Barragem da Orca (Fundão). Vista geral do aterro na margem esquerda, de jusante, notando-se a escarpa da brecha

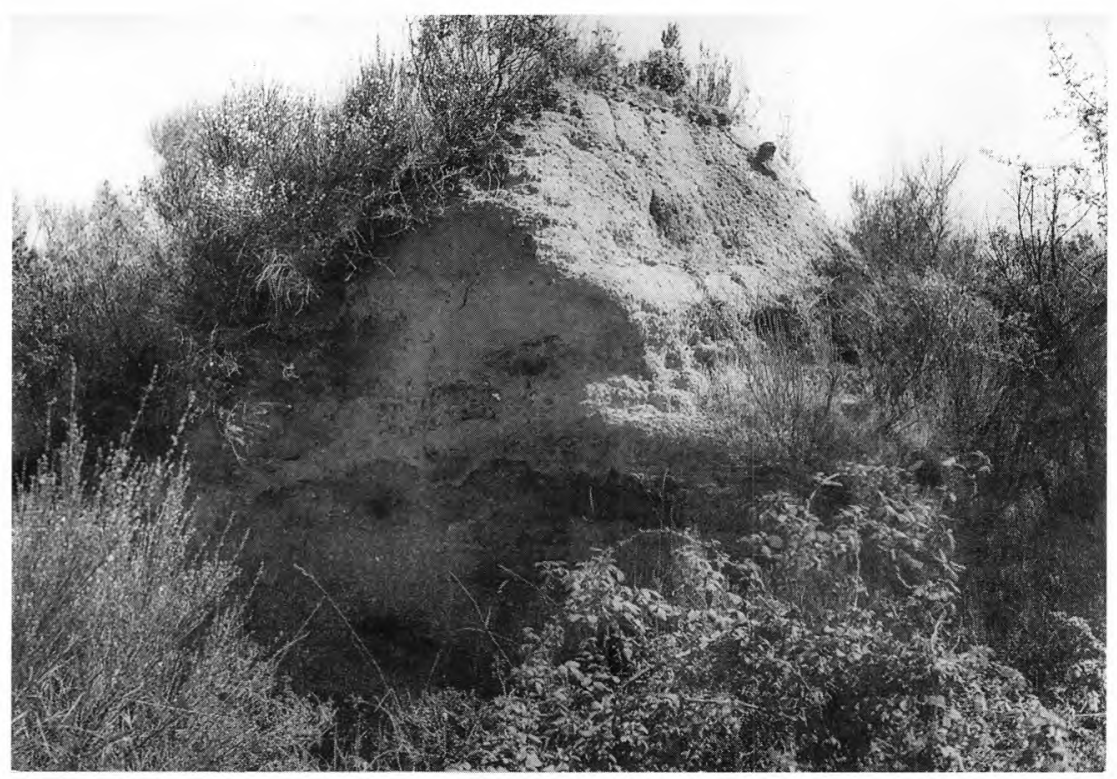

Fото 4 - Barragem da Orca (Fundão). Vista da brecha na margem esquerda 


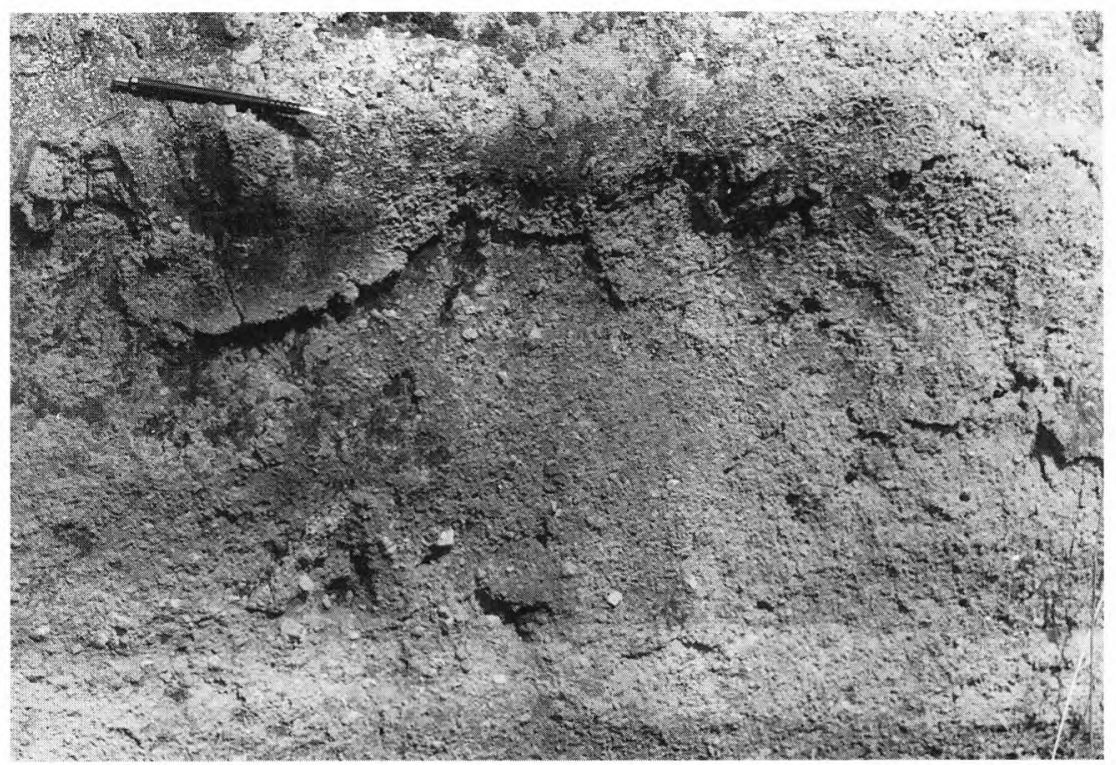

FOTо 5 - Barragem da Orca (Fundão). Vista do pormenor da estrutura do aterro na brecha, evidenciando a execução do aterro por camadas

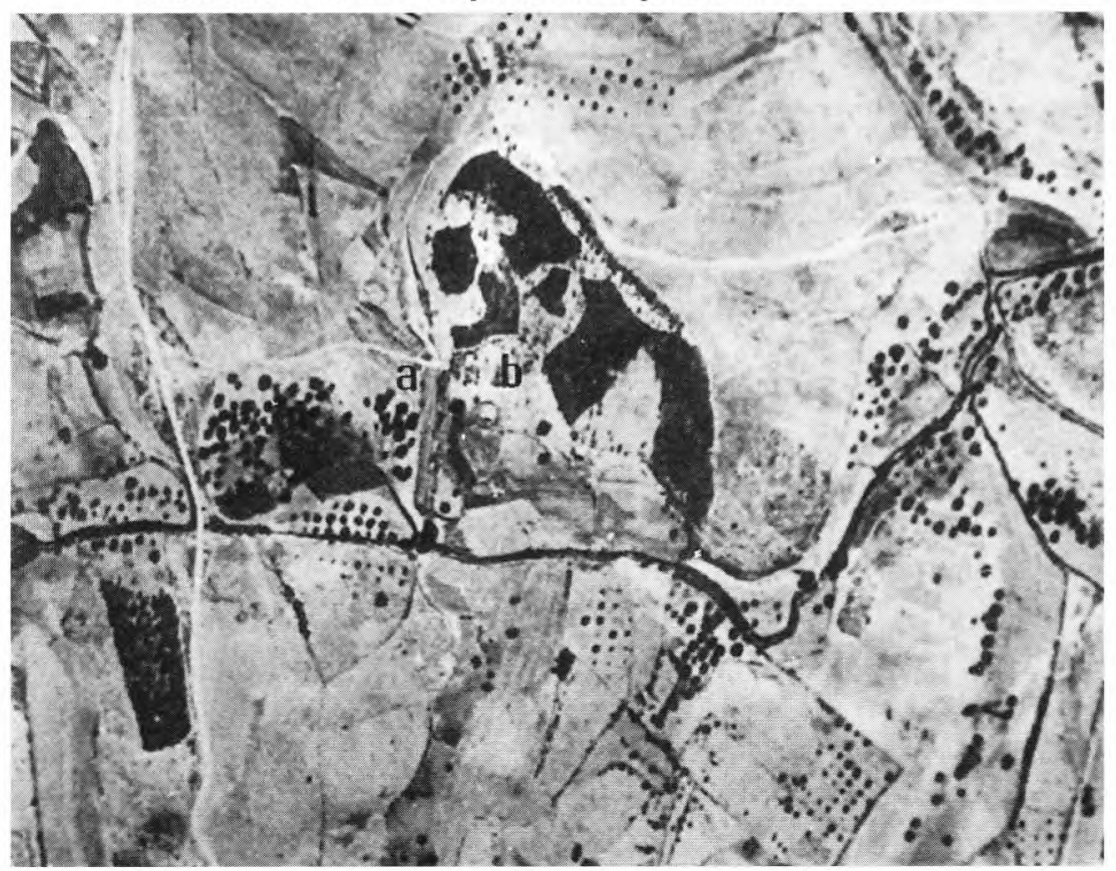

Foto 6 - Barragem da Orca (Fundão). Fotografia aérea vertical, reconhecendo-se a barragem (a) e a zona de movimentação de terras (b) 


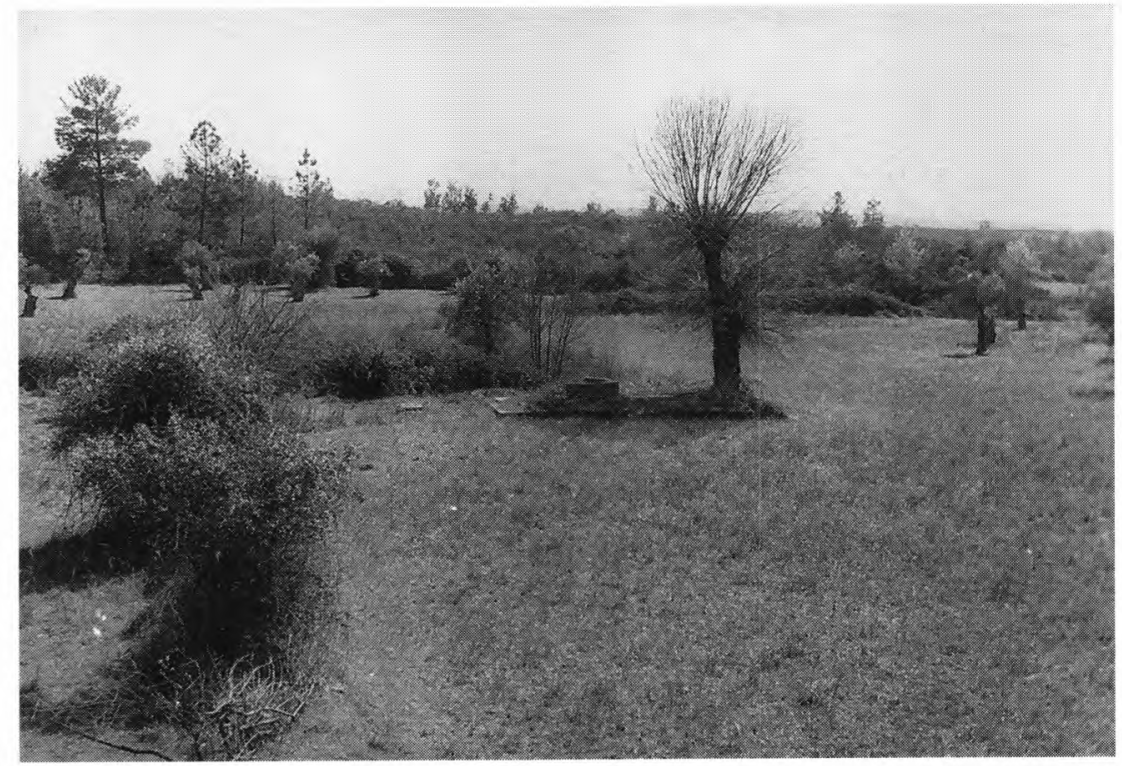

FOTо 7 - Barragem da Orca (Fundão). Vista parcial da área da antiga albufeira, assoreada, obtida da margem esquerda, notando-se a estrutura hidráulica com poço

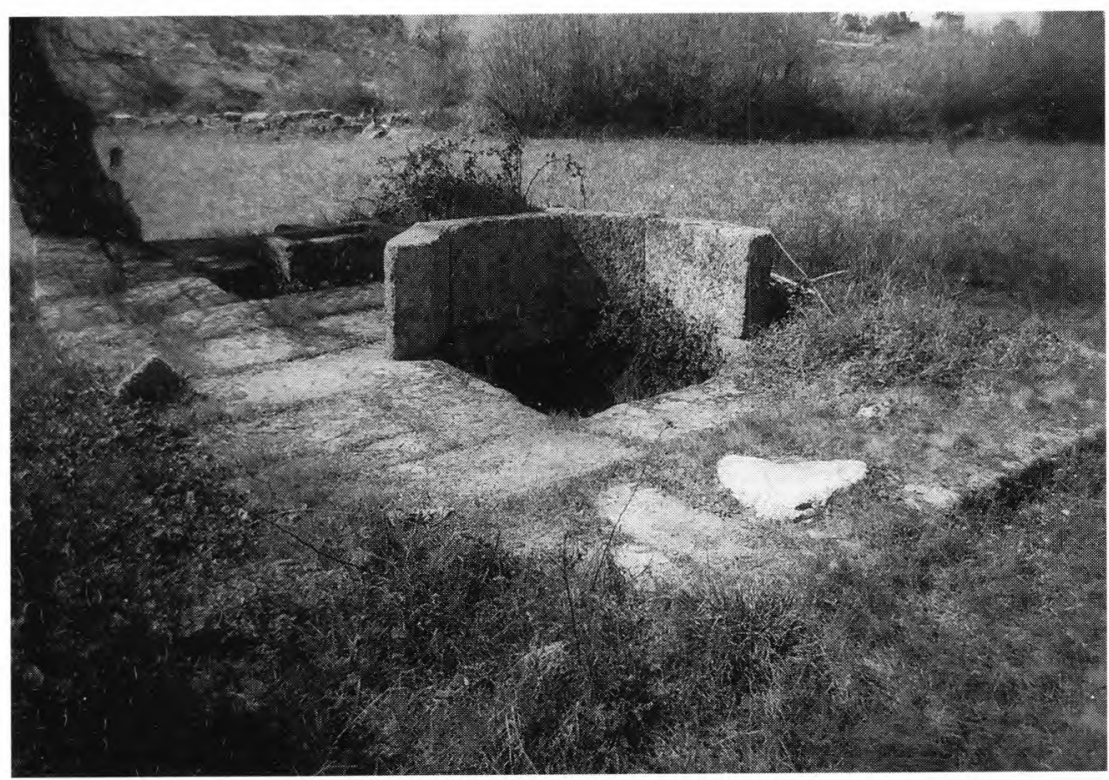

FOTо 8 - Barragem da Orca (Fundão). Pormenor da estrutura hidráulica, com lajeado, poço e tanque 


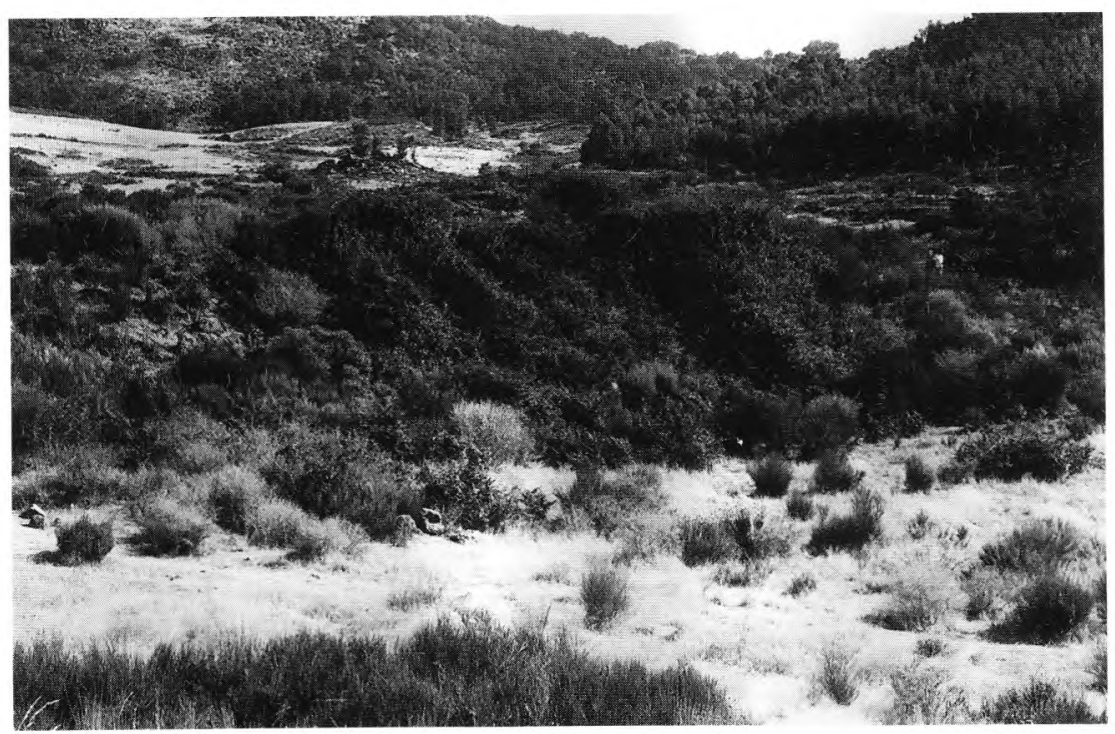

Fото 9 - Barragem do Rochoso (Idanha-a-Nova). Vista geral do aterro na margem direita. observando-se na zona central o talude de jusante, coberto de mato, e o de montante, com pendente mais suave, em pousio

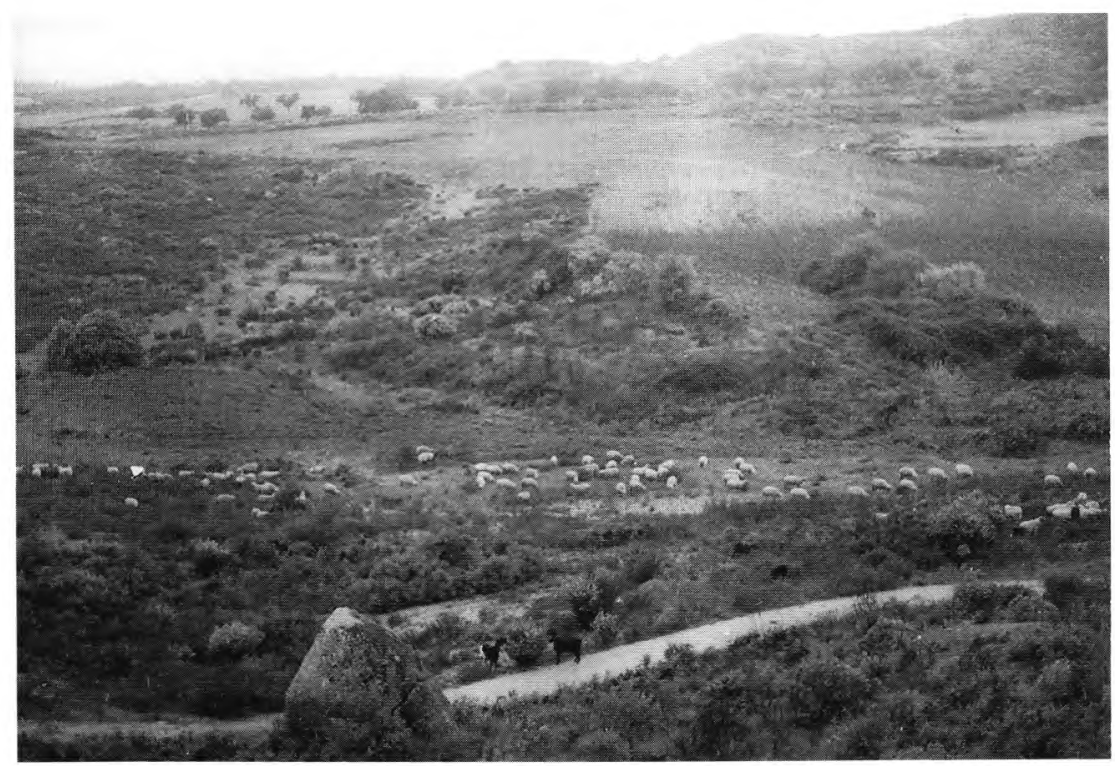

Foто 10 - Barragem do Rochoso (Idanha-a-Nova). Margem direita vista de jusante 


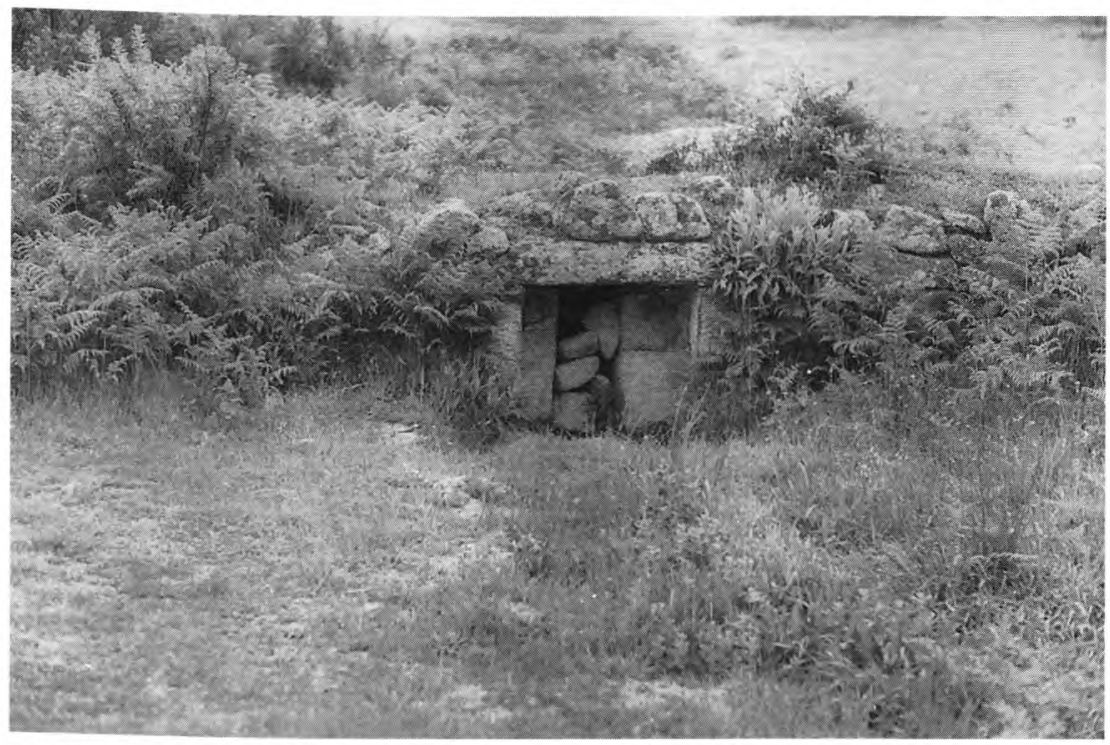

Foto 11 - Barragem do Rochoso (Idanha-a-Nova). Fonte provavelmente romana, a cerca de $500 \mathrm{~m}$ a montante da barragem, que alimentava a villa de S. Lourenço

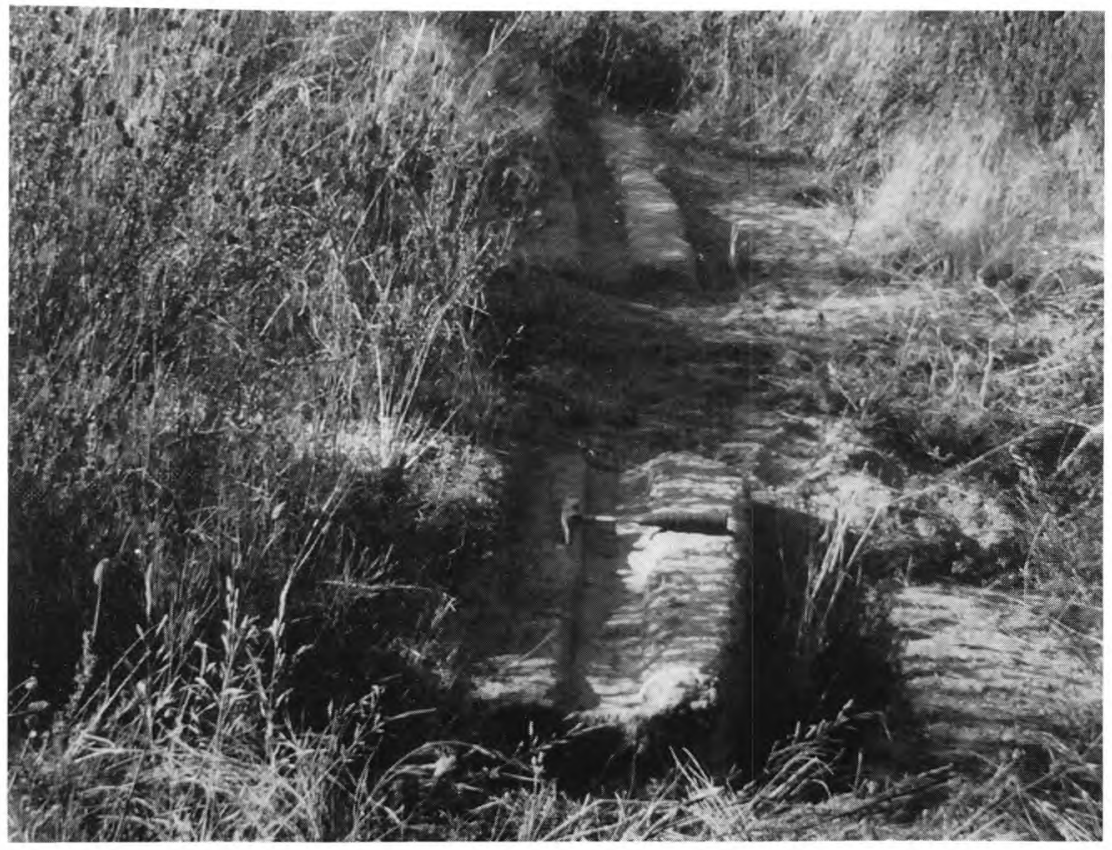

Fото 12 - Barragem do Rochoso (Idanha-a-Nova). Caleira de granito, junto do encontro esquerdo da barragem 


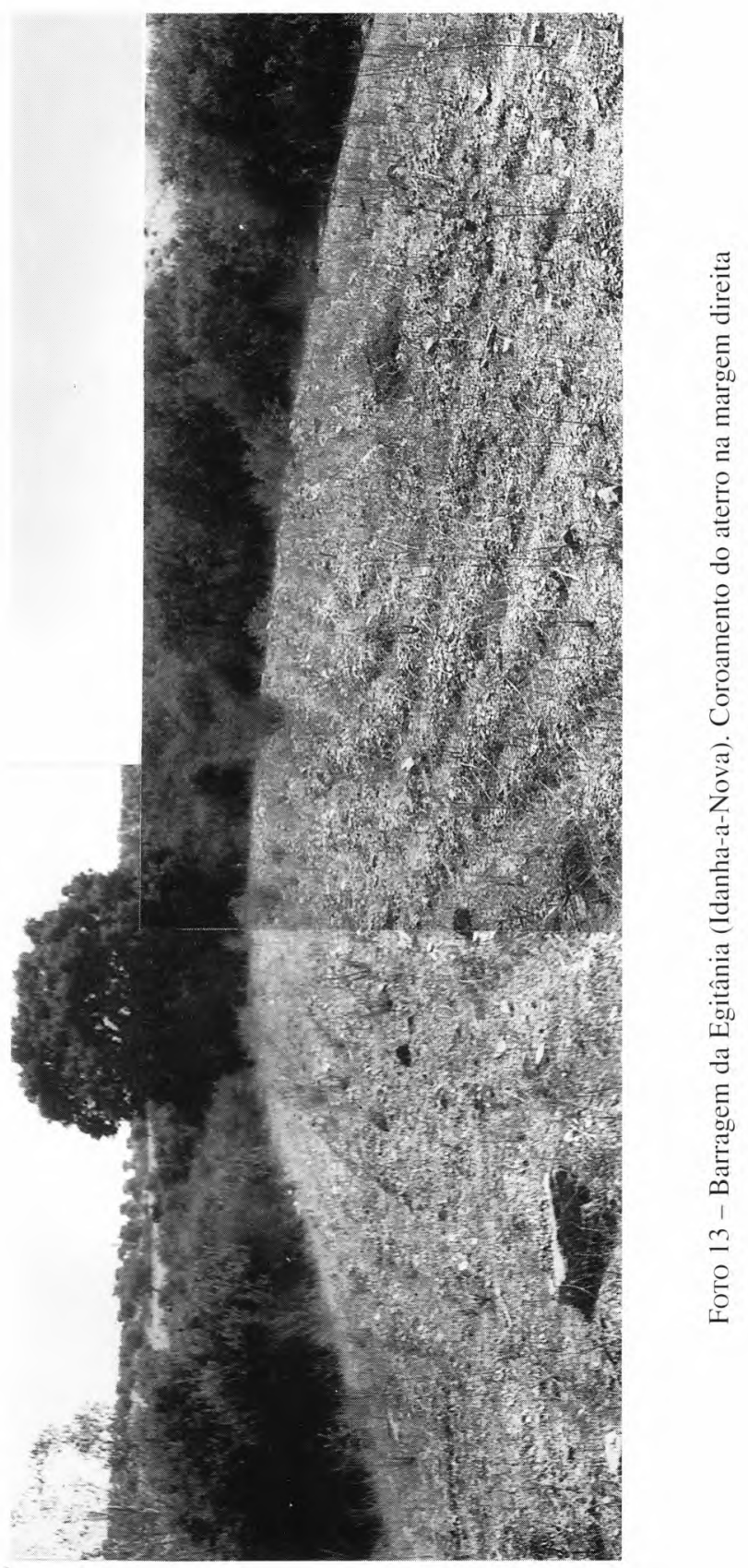




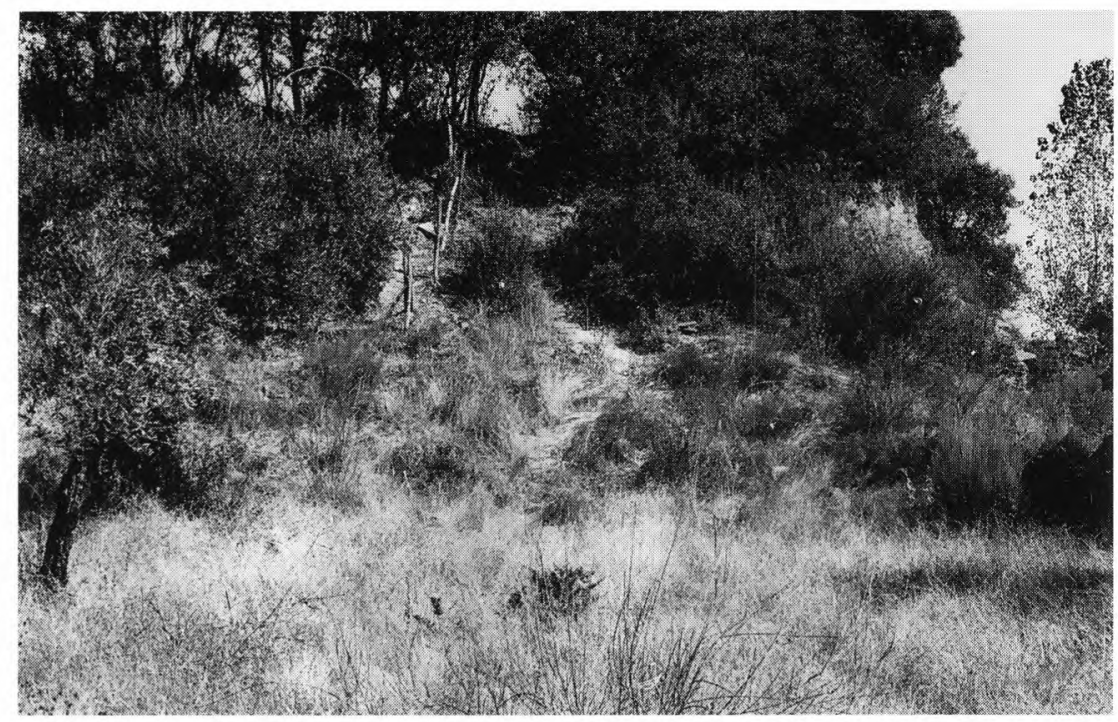

Fото 14 - Barragem da Egitânia (Idanha-a-Nova). Vista de jusante, notando-se à direita o início do talude da brecha

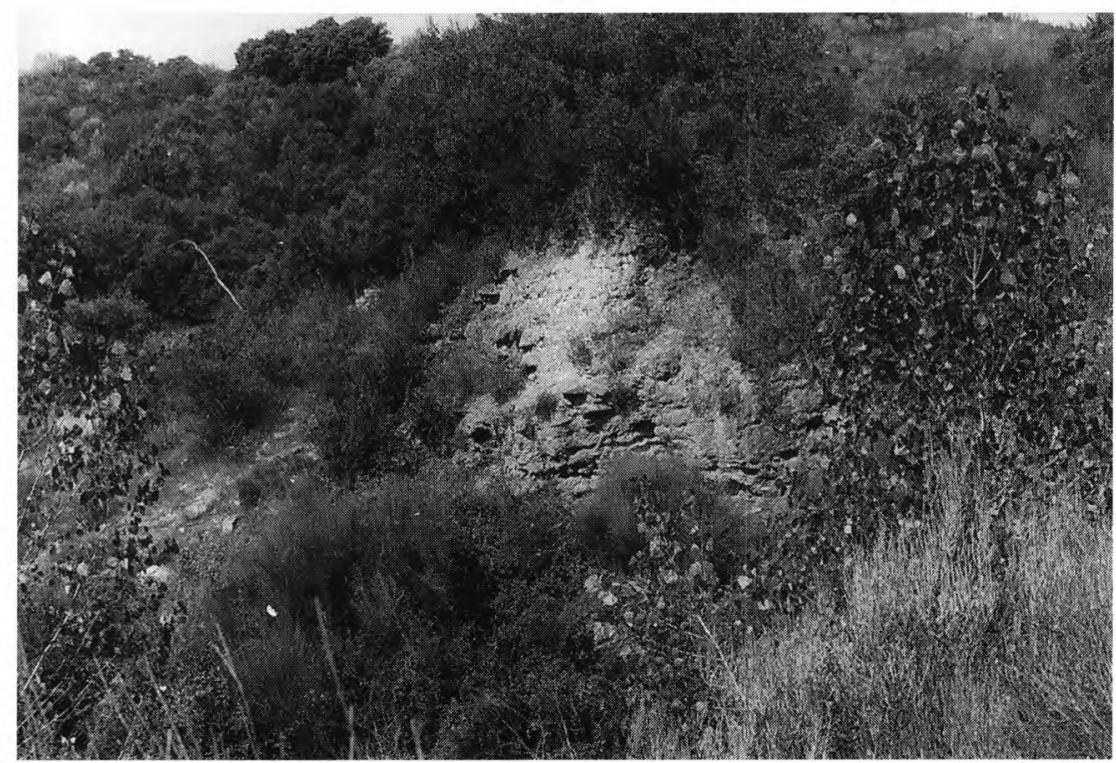

Fото 15 - Barragem da Egitânia (Idanha-a-Nova). Talude da brecha, da margem direita, observado da margem esquerda 


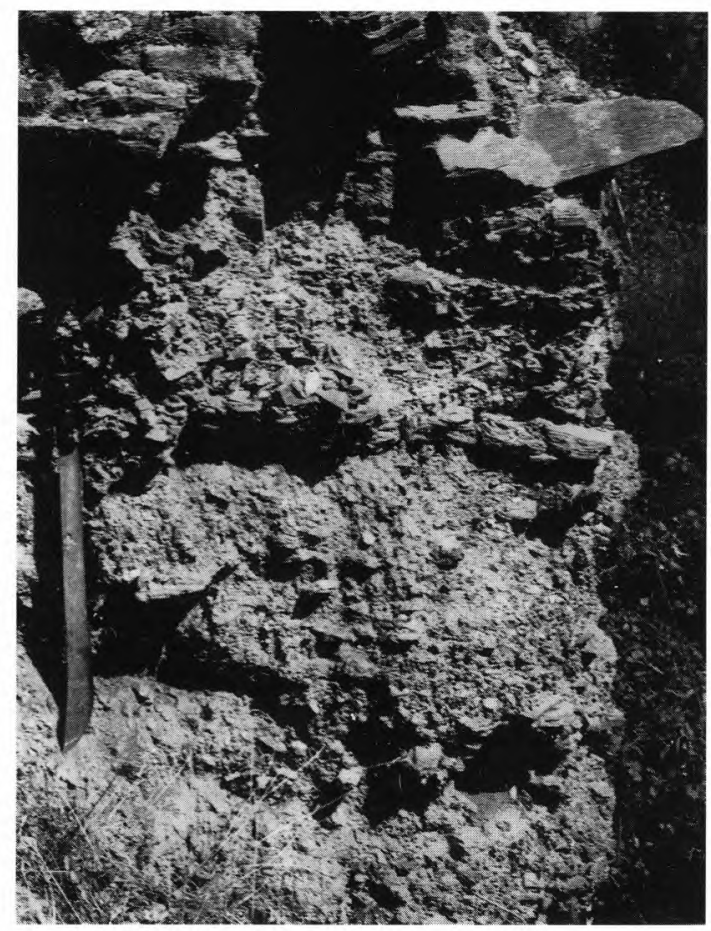

FoTO 16 - Barragem da Egitânia (Idanha-a-Nova).

Pormenor da estrutura do aterro 


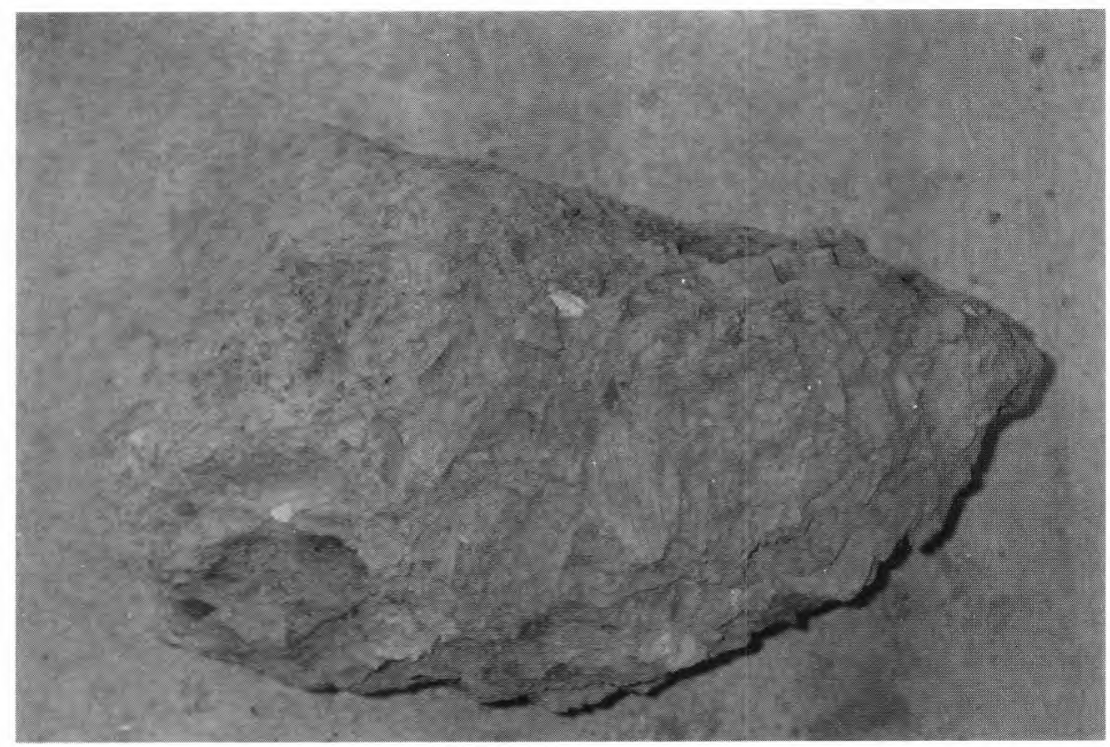

FOTо 17 - Barragem da Egitânia (Idanha-a-Nova). Bloco desmoronado do aterro

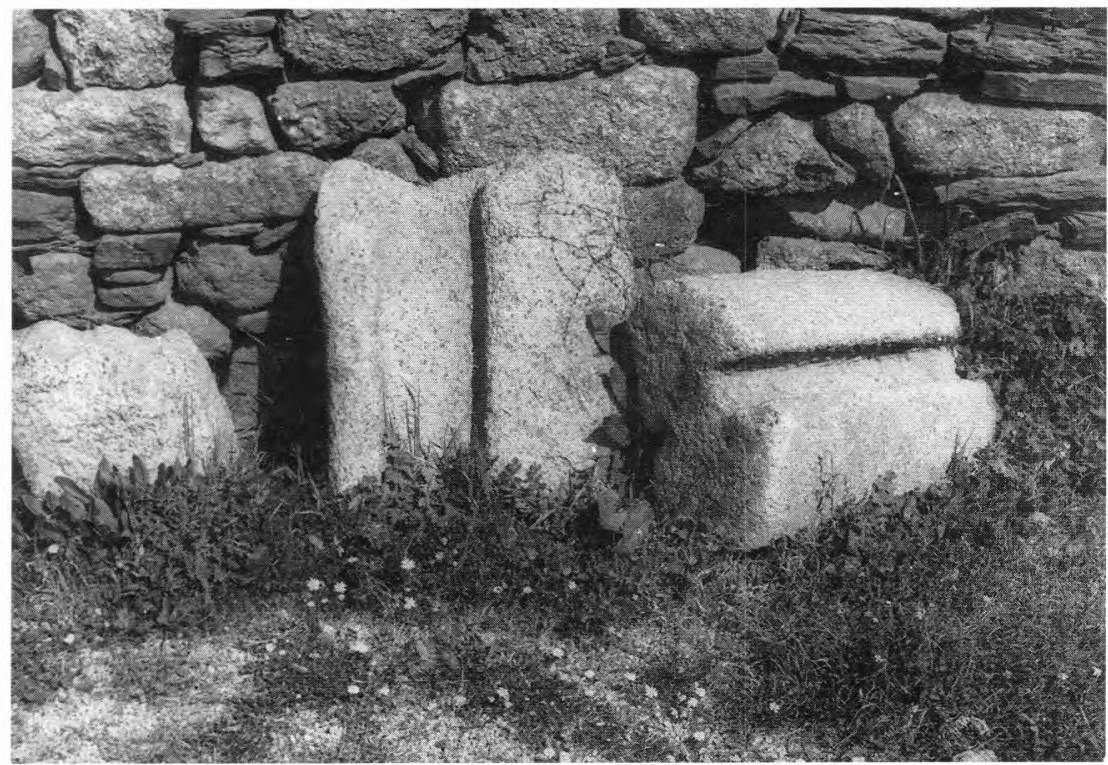

Foto 18 - Barragem da Egitânia (Idanha-a-Nova). Troços de caleira fotografados no adro da torre de menagem de Idanha-a-Velha 


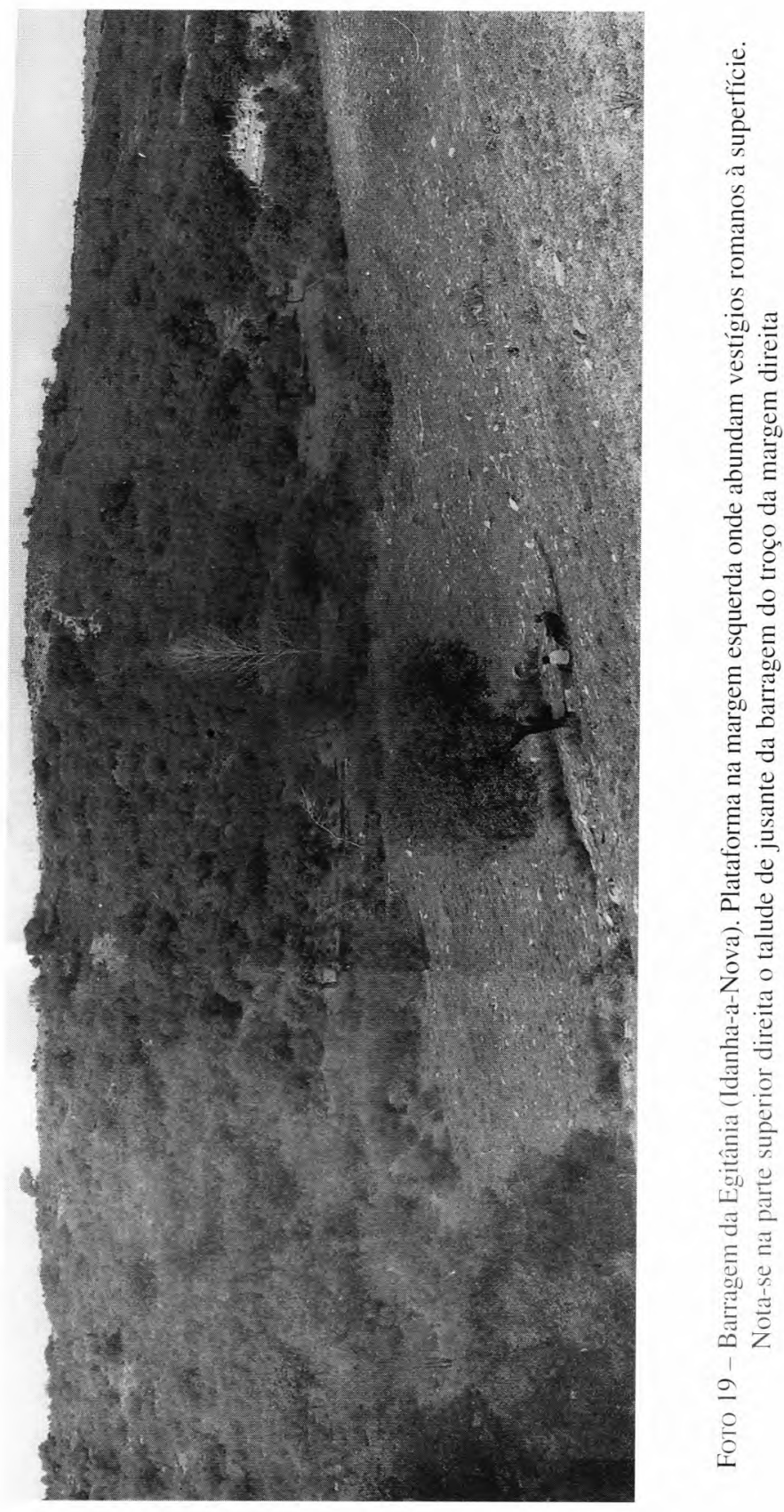




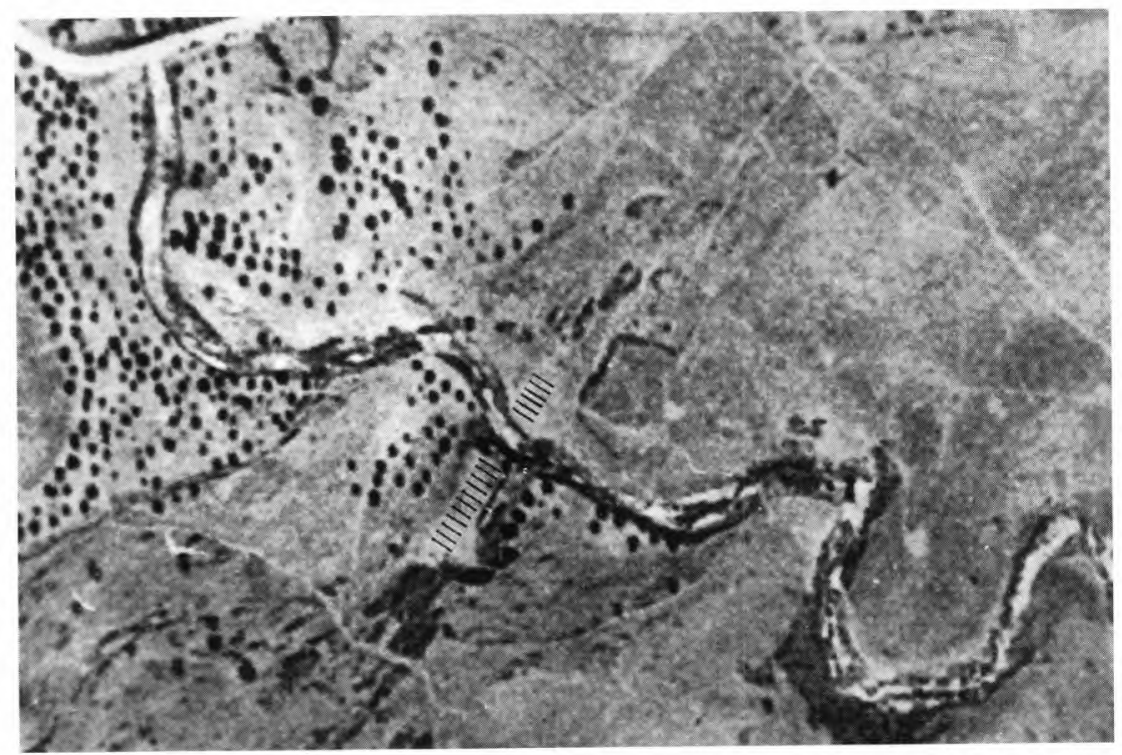

Fото 20 - Barragem da Egitânia (Idanha-a-Nova). Fotografia aérea vertical, reconhecendo-se a barragem (tracejado) 


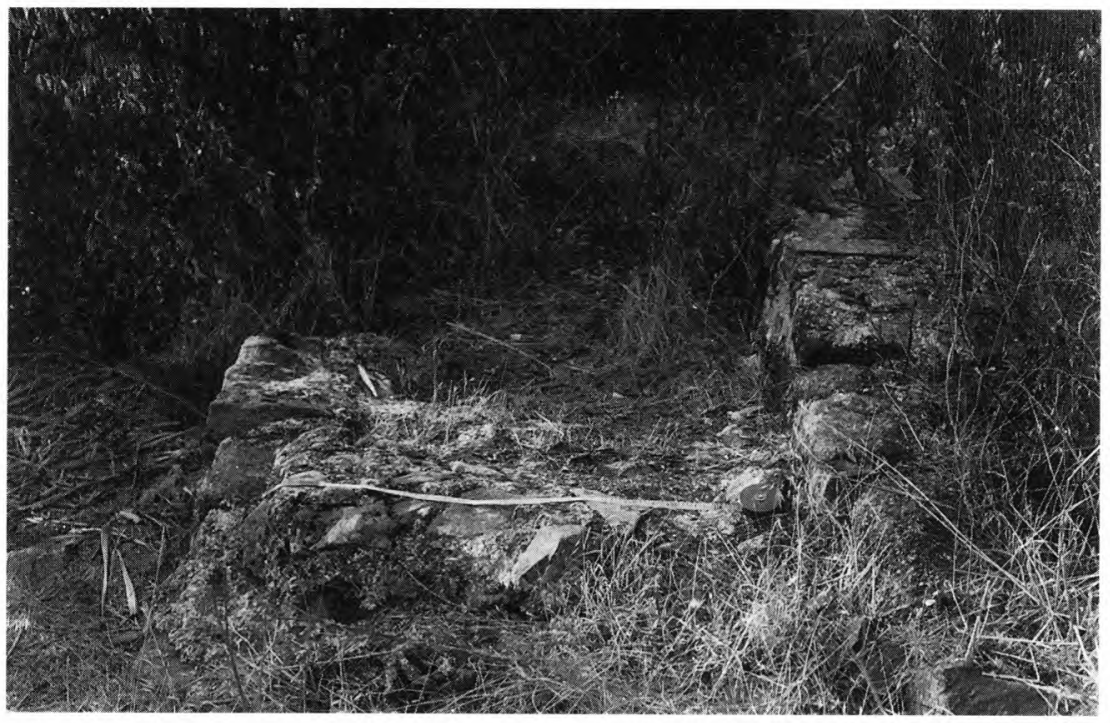

Fото 21 - Barragem de Nossa Senhora de Mércoles (Castelo Branco)

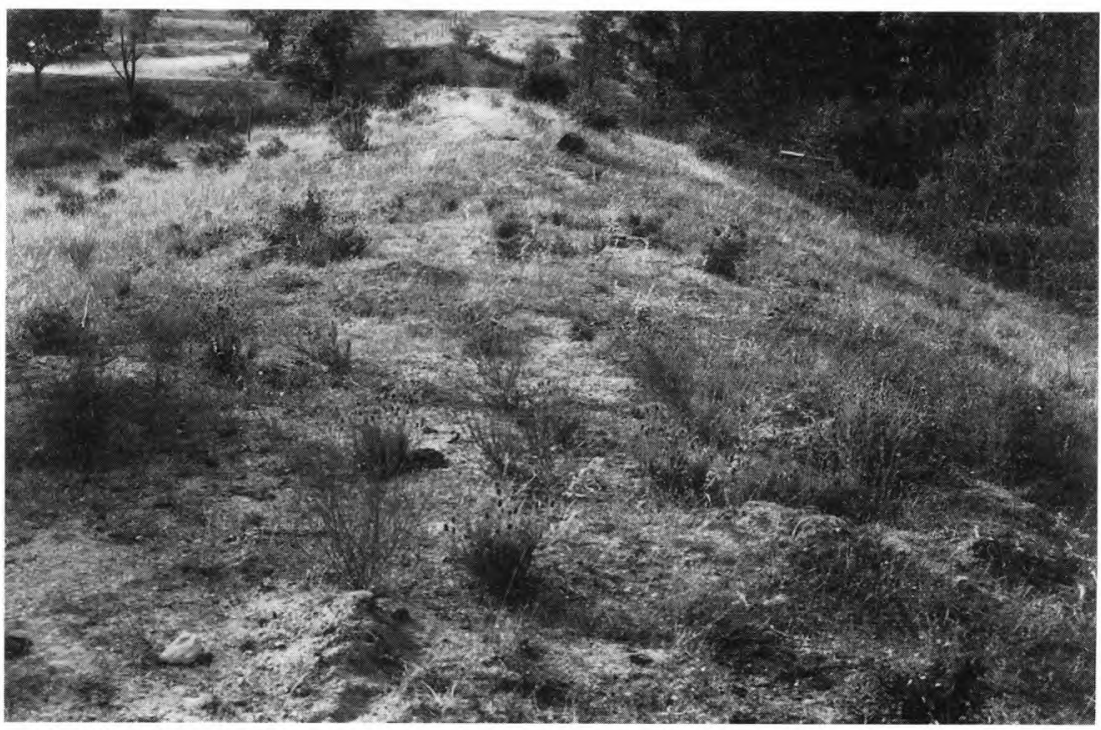

Foто 22 - Barragem de Monforte (Castelo Branco). Vista geral do aterro obtida para a margem direita 


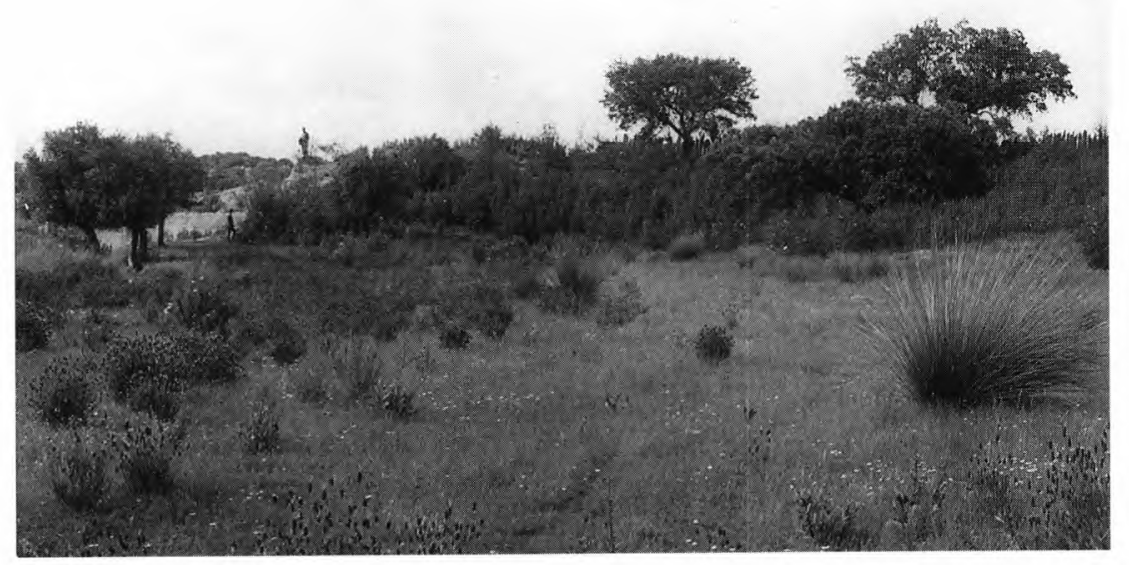

Fото 23 - Barragem da Lameira (Vila Velha de Ródão). Vista do aterro, obtida de jusante na margem esquerda

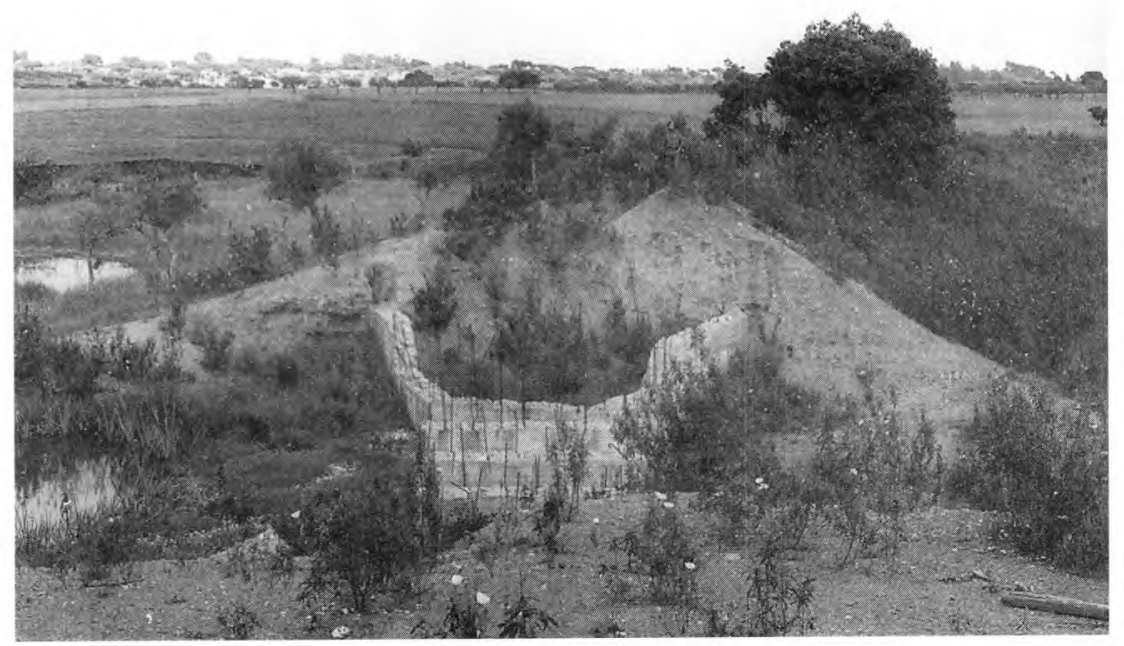

Foто 24 - Barragem da Lameira (Vila Velha de Ródão). Vista da brecha e da estrutura recente de betão, a partir do aterro na margem direita 


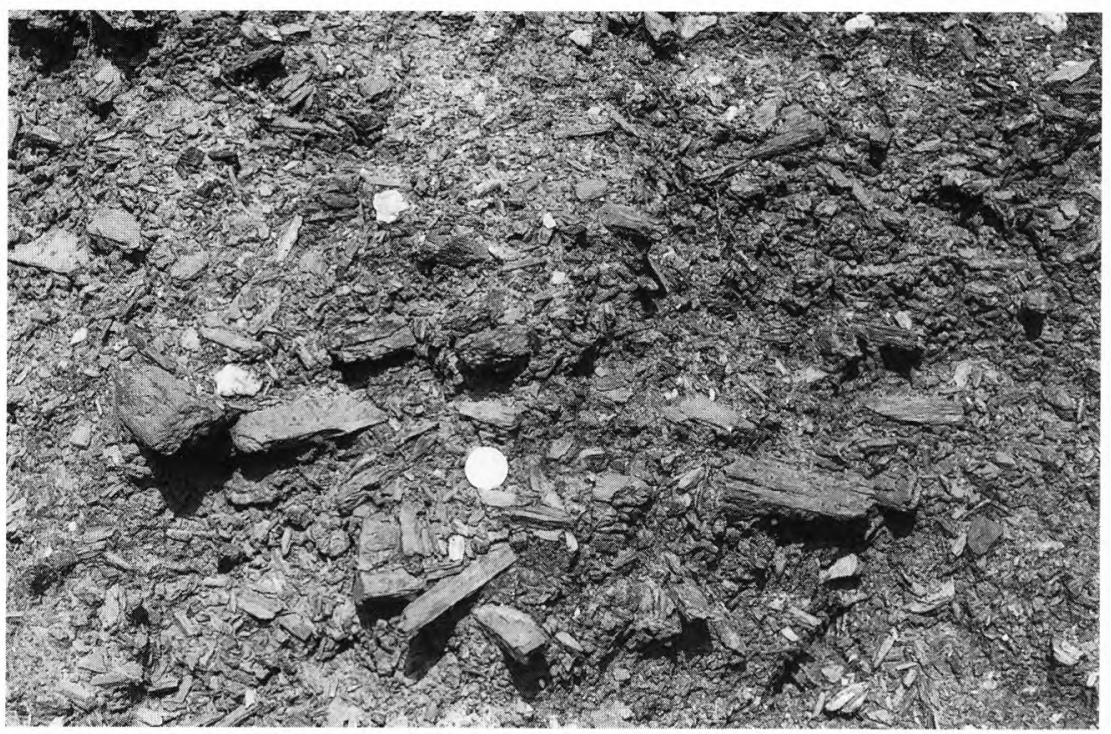

Foтo 25 - Barragem da Lameira (Vila Velha de Ródão). Estrutura do aterro, aparente no talude da brecha na margem esquerda, notando-se uma moeda de $31 \mathrm{~mm}$ de diâmetro

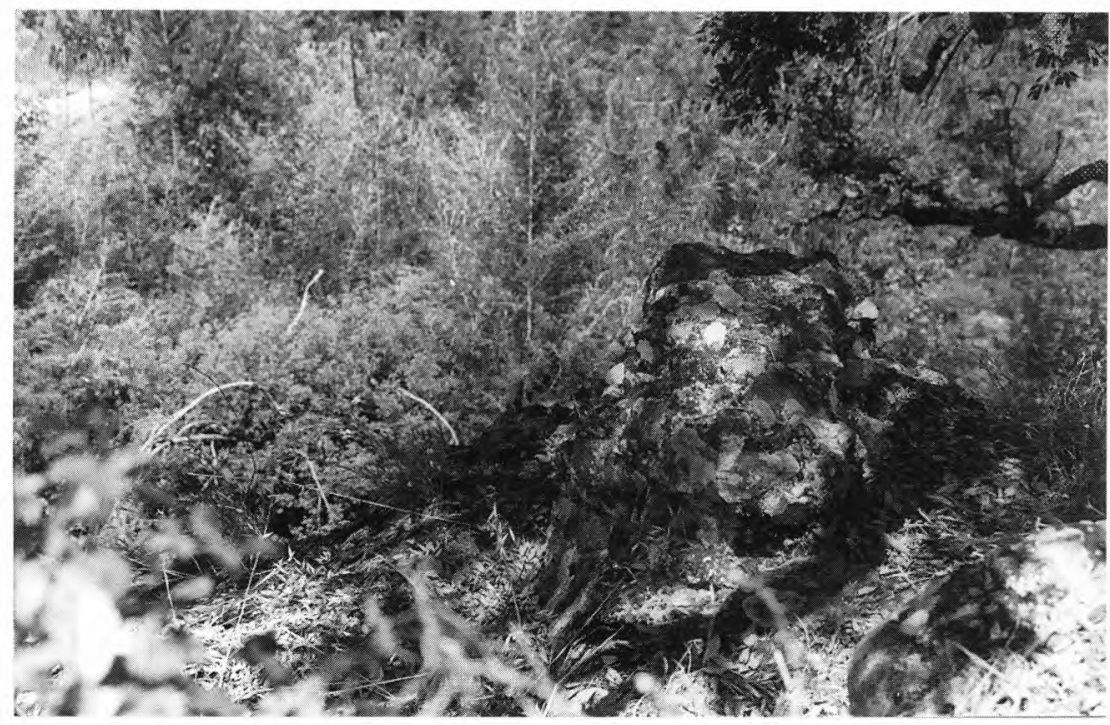

Foto 26 - Barragem do Souto do Penedo (Vila de Rei). Resto do muro no topo do penedo 


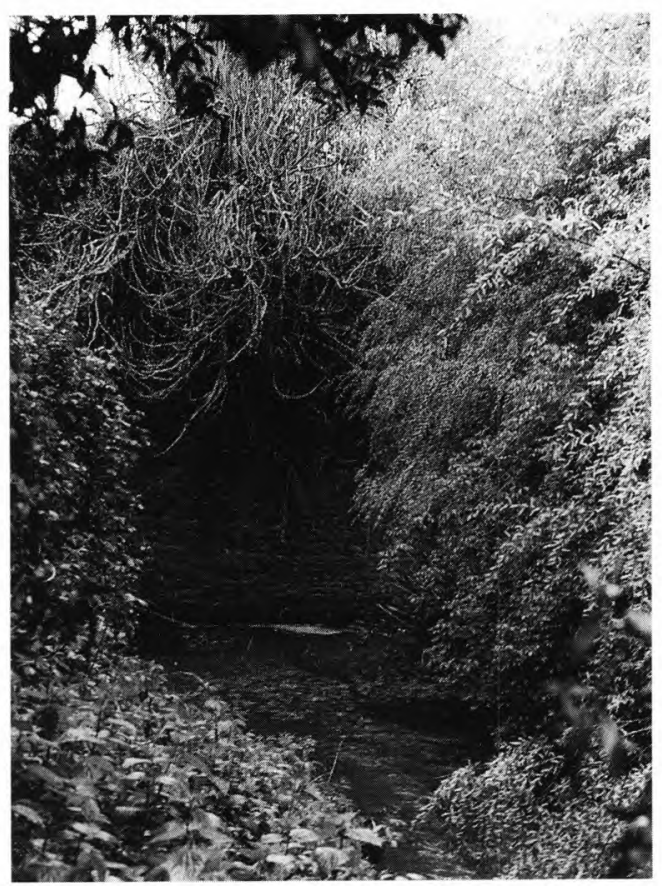

FOTO 27 - Barragem de Alferrarede (Abrantes). Vista do paramento de montante, antes da desmatação

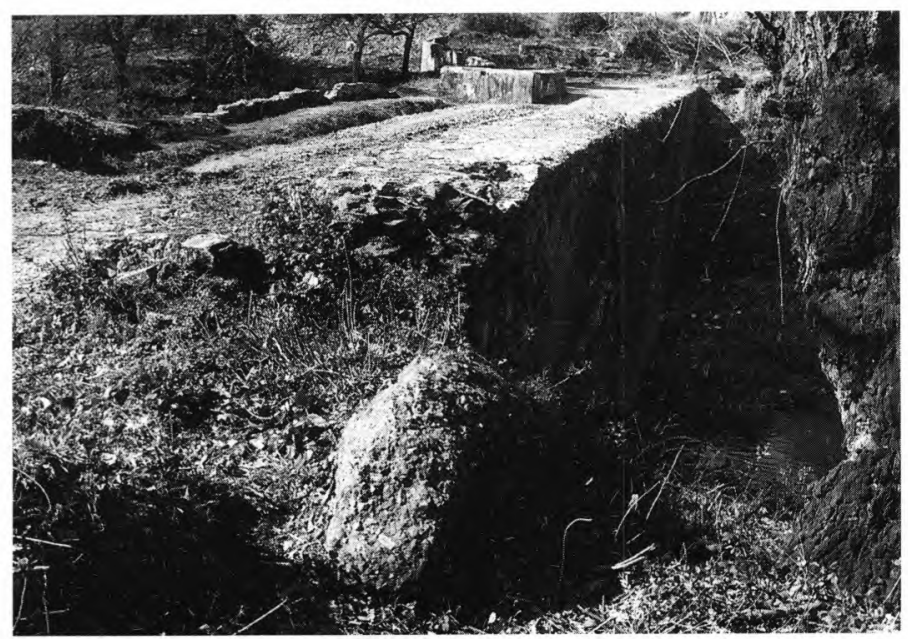

Fото 28 - Barragem de Alferrarede (Abrantes). Vista do coroamento e do paramento de montante, obtida da margem esquerda. Nota-se, em primeiro plano, um bloco de opus signinum, que pertenceria à primitiva barragem romana 


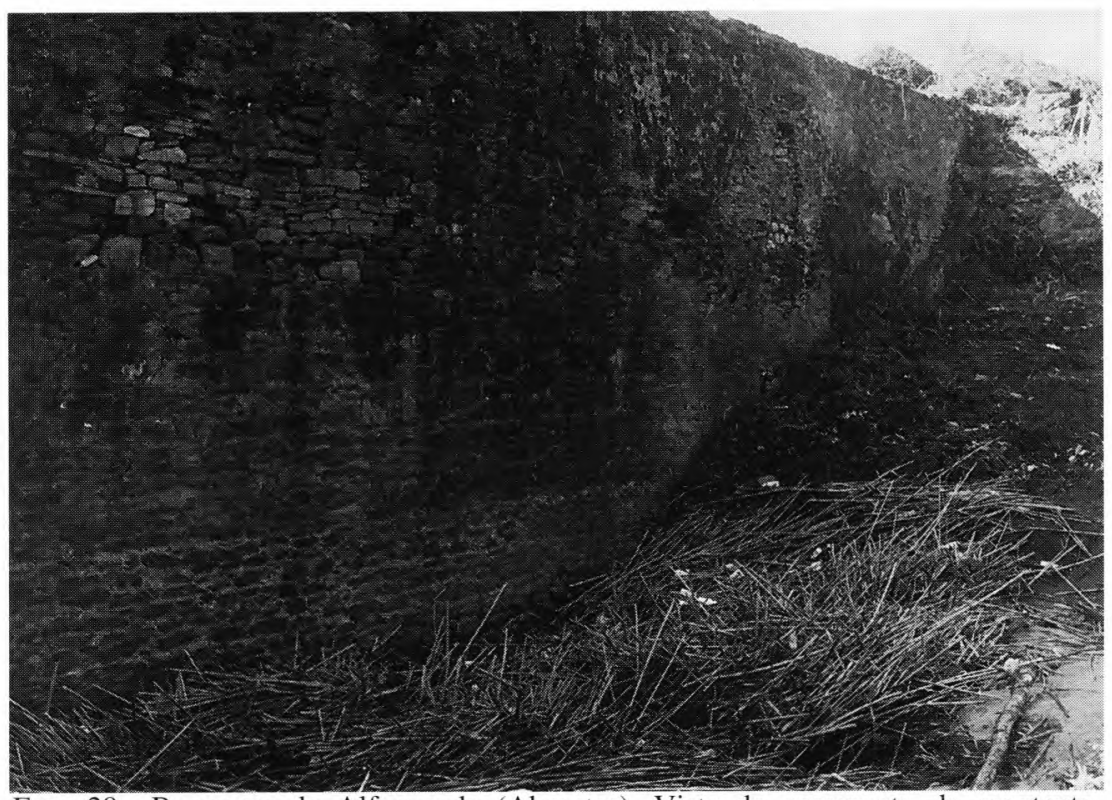

FOTо 29 - Barragem de Alferrarede (Abrantes). Vista do paramento de montante, notando-se, próximo do extremo da margem direita, restos de muro de opus signinum da primitiva barragem romana

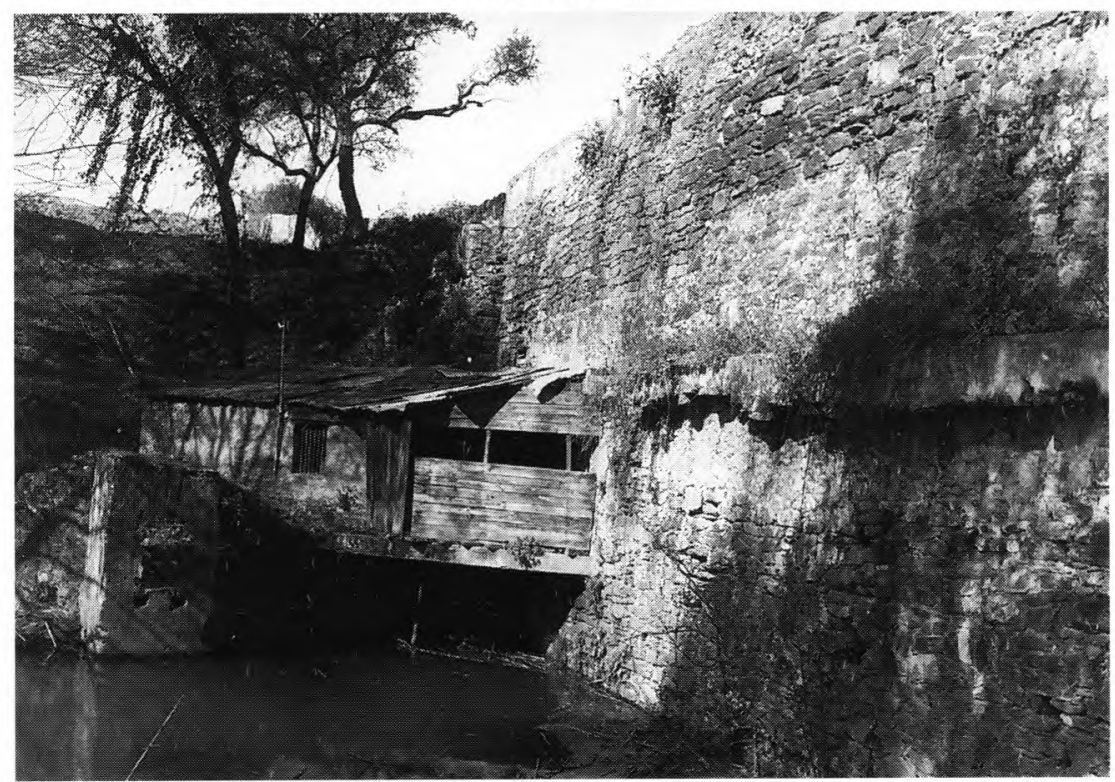

FOTO 30 - Barragem de Alferrarede (Abrantes). Vista do paramento de jusante a partir da margem esquerda, notando-se, restos de moinho e caleira adossada ao muro, a meia altura 


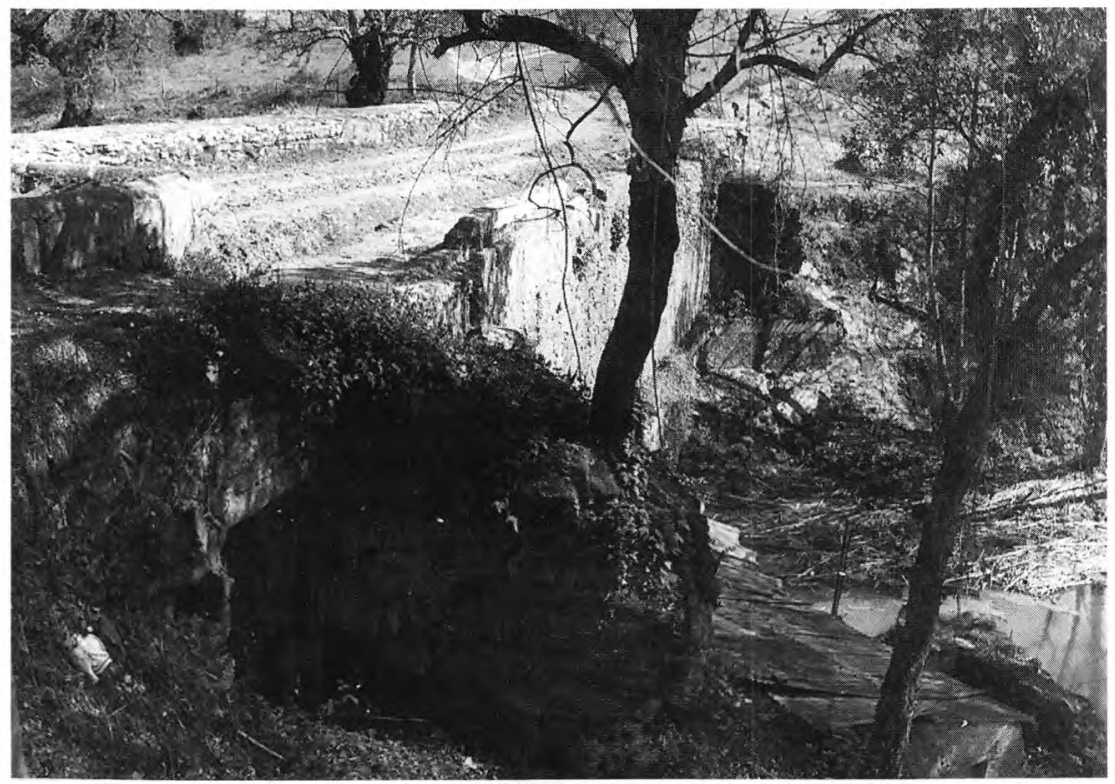

Fото 31 - Barragem de Alferrarede (Abrantes). Vista de jusante, notando-se em primeiro plano a saída de uma galeria transversal à barragem

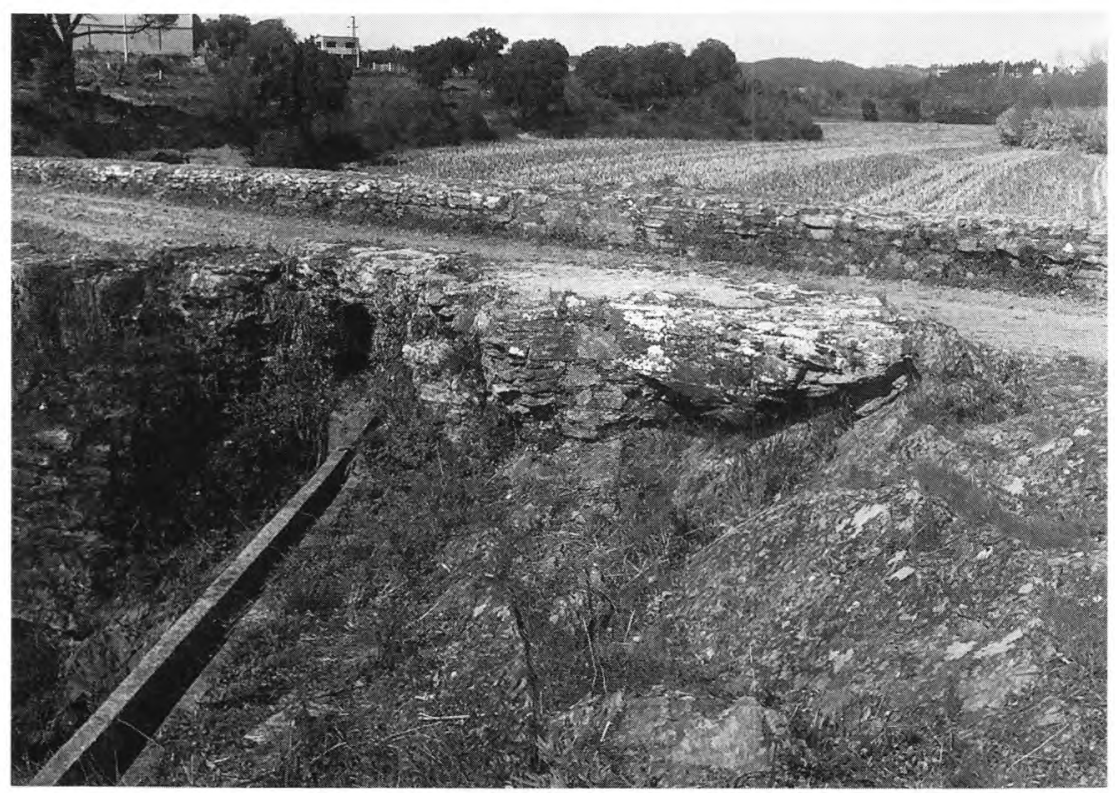

Fото 32 - Barragem de Alferrarede (Abrantes). Vista de jusante, notando-se, em primeiro plano, uma caleira de construção recente e, em último plano, a albufeira assoreada 


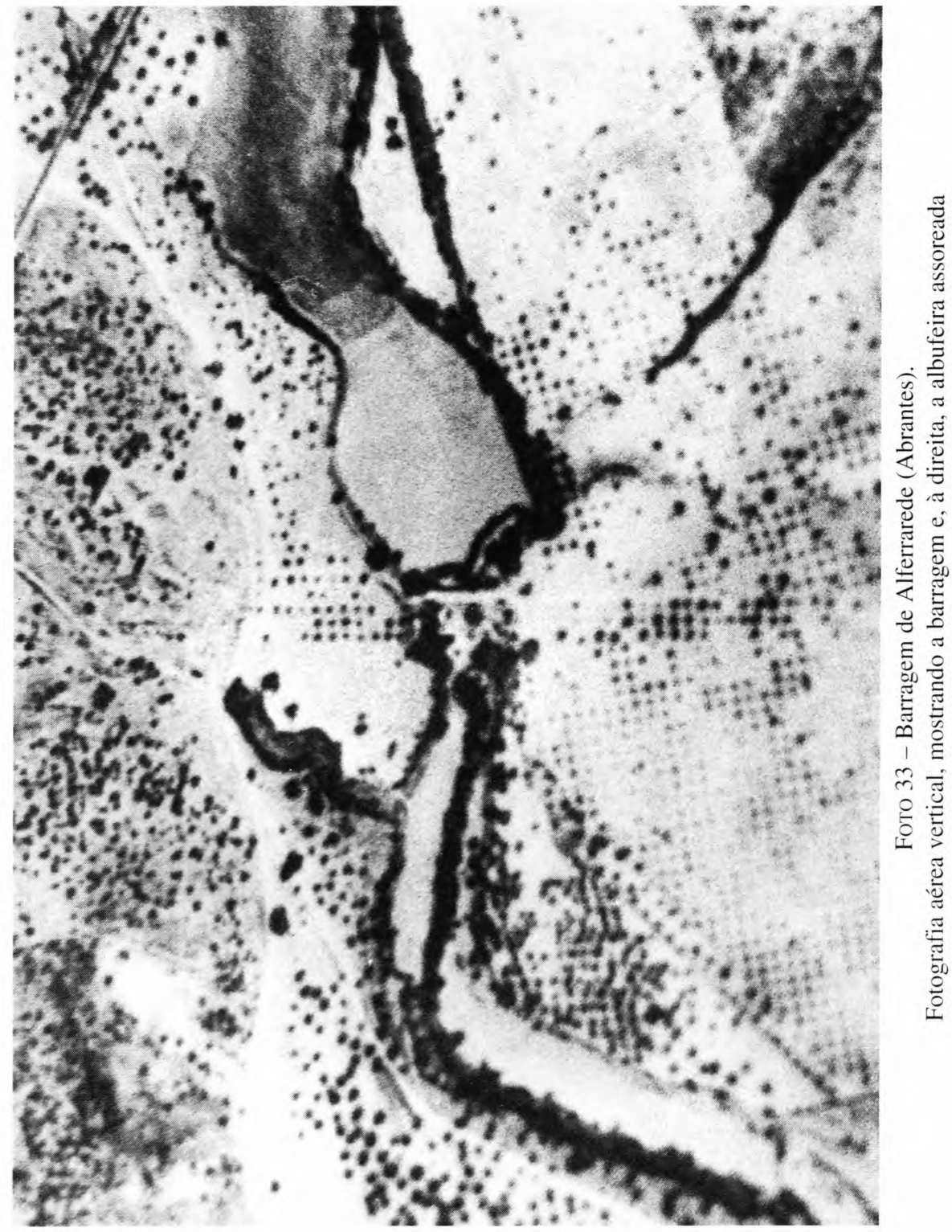




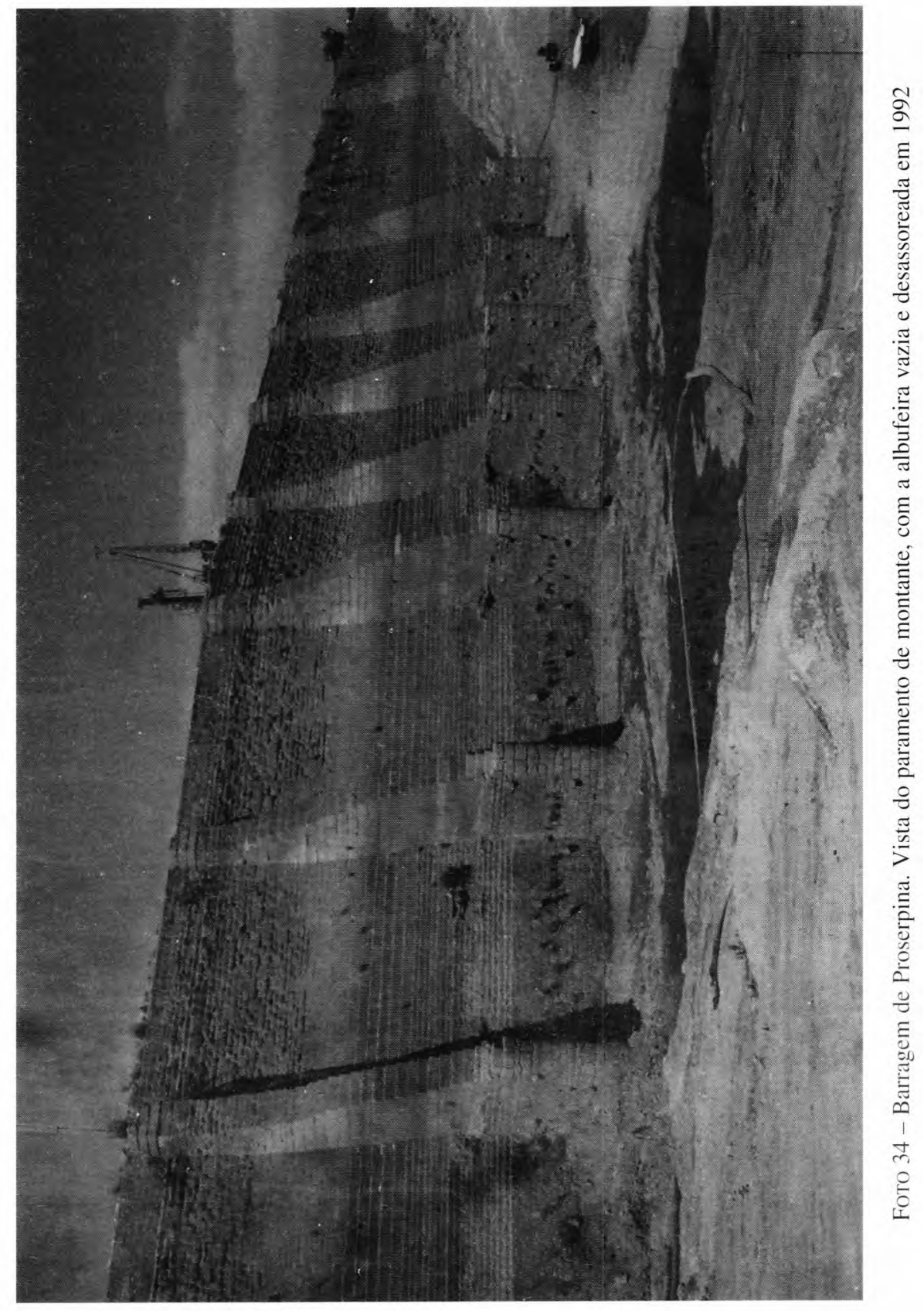

